Historic, Archive Document

Do not assume content reflects current scientific knowledge, policies, or practices. 

STANDARD WEIGHTS OF VARIOUS ARTICLES.

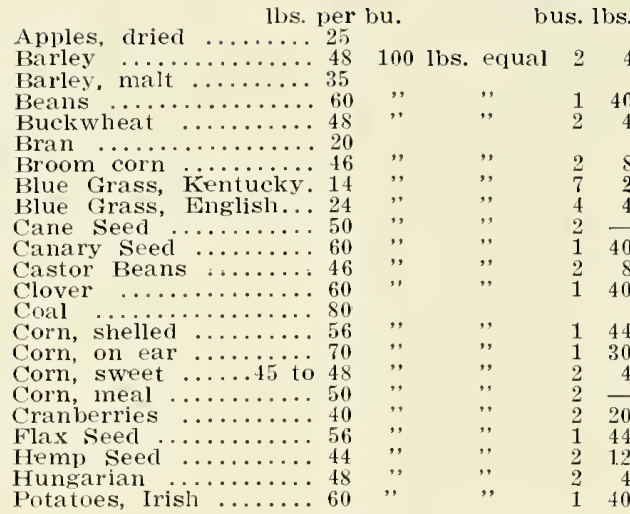

\begin{tabular}{|c|c|c|c|c|}
\hline lbs. per & & & us. & los. \\
\hline Potatoes, sweet & $100 \mathrm{lbs}$. & equal & 2 & \\
\hline Johnson Grass .......25 & & & 4 & \\
\hline Kaffir Corn ......... 56 & , & , & 1 & 44 \\
\hline Millet $\ldots \ldots \ldots \ldots \ldots 50$ & $\because$ & $"$, & 2 & \\
\hline Malt $\ldots \ldots \ldots \ldots \ldots \ldots 38$ & ", & ", & 2 & 24 \\
\hline Oats $\ldots \ldots \ldots \ldots \ldots \ldots 2$ & ," & " & 3 & \\
\hline Osage Orange $\ldots$. & $"$ & $\because$ & 3 & 1 \\
\hline Orchard Grass ... & ", & ", & 7 & 2 \\
\hline Onions $\because \ldots \ldots \ldots \ldots \ldots 54$ & ", & ", & 1 & $4 \overline{6}$ \\
\hline Peas, wrinkled .......56 & $" 0$ & " & 1 & 44 \\
\hline 1'eas, smooth ........ fio & $"$ " & " & 1 & 40 \\
\hline jeas, cow ......... 50 & 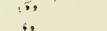 & 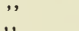 & 2 & \\
\hline Rape $\quad \ldots \ldots \ldots \ldots \ldots 50$. & " & ", & 2 & \\
\hline Rye $\ldots \ldots \ldots \ldots \ldots \ldots 56$ & " & ," & 1 & 44 \\
\hline Red Top .......... 14 & $\ddot{\prime \prime}$ & ", & 7 & 2 \\
\hline Sweet Potatoes ....... 56 & " & " & 1 & 44 \\
\hline Timothy Seed .... & 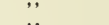 & $"$ & 2 & 10 \\
\hline Turnips .......... 58 & " & ", & 1 & 12 \\
\hline Wheat $\ldots \ldots \ldots \ldots \ldots \ldots 60$ & , & " & 1 & 10 \\
\hline Tall Meadow Oat Grass 12 & " & " & & \\
\hline Lawn Grass ........14 & , & " & & \\
\hline Pasture Grass Mixture 14 & " & ", & & 2 \\
\hline
\end{tabular}

QUALITY OF SEED USUALLY SOWN PER ACRE.

Quantity per acre. Artichoke, 1 oz. to 500 plants........ 6 oz. Asparagus, 1 oz. to 800 plants........

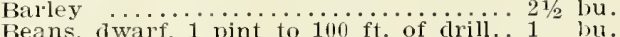
Beans, dwarf, 1 pint to $100 \mathrm{ft}$. of drill.. 1 bu

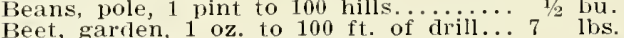

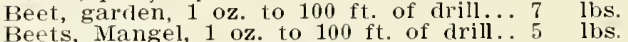
Brocoli, 1 oz to 5,000 plants.......... Brussels sprouts, $1 \mathrm{oz}$. to 5,000 plants...2 2 oz Buckwheat $\ldots \ldots \ldots \ldots \ldots \ldots \ldots$
Cabbage, 1 oz. to 5,000 plants... bu. Carrots, $1 / 1$ oz. to $100 \mathrm{ft}$. of drill....... $21 / 2 \mathrm{lbs}$. Cauliflower, $1 \mathrm{oz}$ to 5,000 plants........ $2 \frac{2}{1 / 2} \mathrm{oz}$. Celery, $1 \mathrm{oz}$. to 15,400 plants.......... Chicory $\ldots \ldots \ldots \ldots \ldots \ldots \ldots \ldots \ldots \ldots$ lbs Clover, Alsike and White....... 8 to 10 los. Clover, Lucerne ............... 15 to 25 lbs. Clover, Crimson Trefoil..............10 to 15 ths Clover, large red and medium....10 to 14 lbs. Collards, 1 oz. to 5,000 plants........ 2 oz. Corn, rice (shelled).................... Corn, sweet, $1 / 4$ pint to 100 hills........6 qts. Cress, $3 / 4$ oz. to $100 \mathrm{ft}$. of drill........ Cucumber, 1 oz. to 100 hills....... to 3 lbs.

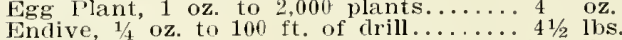
Flax, broadeast ..........40 to 50 lbs. Garlic, bulbs, 1 1b. to $10 \mathrm{ft}$ of drill... Gourd Grass, Blue Kentucky ............

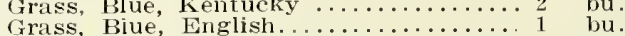
Grass, Bue, English. $\ddot{1}$ Mungarian and $\ldots \ldots$ i/2 to 1 bu. Grass, mixed, lawn........... 3 to 5 bu Grass, Red Top, fancy clean.... 8 8 to 10 lbs Grass, Timothy ..................

Quantity per acre.

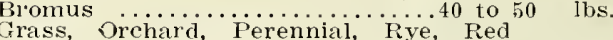

Top, Fowl Meadow and Wood Meadow 2 bu.

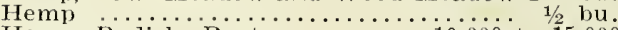
Horse Radish Roots........... Kale, $1 \mathrm{oz}$. to 5,000 plants.......... Kohlrabi, $1 / 3$ oz. to $100 \mathrm{ft}$. of drili........ Teels, $1 / 3 \mathrm{oz}$. to $100 \mathrm{ft}$. of drill.......... Lettuce, $1 / 4 \mathrm{oz}$. to $100 \mathrm{ft}$. of drill......... Martynia, $1 \mathrm{oz}$. to $100 \mathrm{ft}$. of drill....... 5 lbs. Melon, Musk, $1 \mathrm{oz}$. to 100 hills...... Melon, Water, $4 \mathrm{oz}$. to $100 \mathrm{hills...11/2}$ to 4 lbs. Nasturtiums, $2 \mathrm{oz}$. to $100 \mathrm{ft}$. of drill....15 lbs. Okra, 1 oz to $100 \mathrm{ft}$ of drill of drill... Onion seed, 1 to $3 \mathrm{oz}$. to $100 \mathrm{ft}$. drili. 4 to 5 lbs. Onion seed, for sets...........40 to 80 lbs Onion sets, 1 qt. to $40 \mathrm{ft}$. of drili.......8 lbs. Parsnips, $1 / 4$ oz. to $100 \mathrm{ft}$. of drill....... Parsley, $1 / 4$ oz. to $100 \mathrm{ft}$. of drill....... 3 lbs. Peass, garden, $1 \mathrm{pt}$. to $100 \mathrm{ft}$. of drill.1 to $3 \mathrm{hu}$. Peas, field .................... Pepper, 1 oz. to 1,500 plants......... Radish, $2 / 3 \mathrm{oz}$. for $100 \mathrm{ft}$. of drill...10 to 12 lbs.

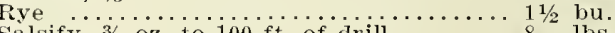
Salsify. $3 / 4$ oz. to $100 \mathrm{ft}$ of drill........ 8 lbs. Spinach, $1 / 2$ oz. to $100 \mathrm{ft}$ of drill........ 8 lbs.

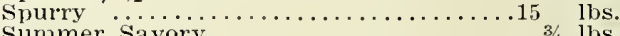
Summer Savory $\ldots \ldots \ldots \ldots \ldots \ldots \ldots \ldots \ldots{ }^{3 / 4}$ lbs. Sunflower $\ldots \ldots \ldots \ldots \ldots \ldots \ldots \ldots \ldots$ s lbs. $_{4}$ Squash, Summer, 4 oz. to 100 hilis..... 2 lbs. Squash, Winter, 8 oz. to 100 hills....... Tohacco, $1 \mathrm{oz}$. to 5,000 plants...........

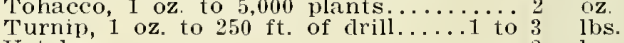
Vetches .....................

\section{GUANTITY OF SEED REQUIRED FOR A GIVEN NUMBER OF PLANTS, NUMBER OF HILLS,} OR LENGTH OF DRILLS.

Asparagus ........... oz. to $60 \mathrm{ft}$. of drill Beet ............... oz. to $50 \mathrm{ft}$ of drill Beans, dwarf ........... q to $100 \mathrm{ft}$. of drill Beans, pole ................ qt. to 150 hills Carrot pole .................................. $150 \mathrm{ft}$ Cabbage ................ oz. to 2,000 plants Cauliflower $\ldots \ldots \ldots \ldots \ldots \ldots \ldots 1$ oz to 2,000 plant Celery ................ oz. to 3,000 plants Cucumber .............. oz. to 50 hills Corn $\ldots \ldots \ldots \ldots \ldots \ldots \ldots$ qt. to $200 \mathrm{ft}$. of drill .

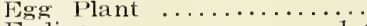
Endive ........... oz. to $150 \mathrm{ft}$ of drill Teek $\ldots \ldots \ldots \ldots \ldots \ldots \ldots \ldots 1$ oz. to $100 \mathrm{ft}$ of drill

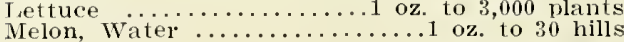

Melon, Musk .............. oz. to 60 hills Okra ............... oz. to $100 \mathrm{ft}$. of dill Onion ............. oz. to $100 \mathrm{ft}$. of drill onion sets, small.......... qu to $40 \mathrm{ft}$ of drill Radish ............................. to $160 \mathrm{ft}$ of dril Parsnips .............. oz. to $200 \mathrm{ft}$. of drill

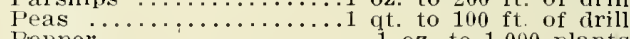
Pepper $\ldots \ldots \ldots \ldots \ldots \ldots \ldots \ldots .1$ oz to 1,000 plants Pumpkin $\ldots \ldots \ldots \ldots \ldots \ldots \ldots \ldots \ldots$ oz. to 40 hills Radish ............. oz. to $100 \mathrm{ft}$ of drill Salsify $\ldots \ldots \ldots \ldots \ldots \ldots \ldots$ oz. to $70 \mathrm{ft}$ of drill Sptnach ................ oz. to $100 \mathrm{ft}$ of drill Squash, early ............. oz. to 50 hills Sqiash, Malrow $\ldots \ldots \ldots \ldots \ldots \ldots \ldots 1$ oz. to 16 hills
Tomato $\ldots \ldots \ldots \ldots \ldots \ldots \ldots$ oz to 1.500 plants

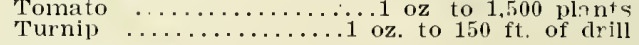

DISCLAIMER.

Complaints are frequently made that seeds do not grow and are not good. This very often may bo attributed to other causes than the quality and vitality of the seed. There are contingencies a ising to prevent even the best of seeds always giving satisfaction, such as sowing too deep, too shallow, or in too wet or too dry soil: insects and worms of all descriptions destroying the plant 3 as soon as or hefore they appear; wet weather; cold weather, frosts, chemical changes in the seeds inducer by temperature, etc. For the above reasons we cannot guarantee seeds under any circumstances.

We give no warranty, express or implied, as to description, purity, productiveness, or any other matter of any seeds we send out, and we will not be in any way responsible for the crop. If the purchaser does not accept the goods on these terms they are at once to be returned. 


\section{SOME REASONS WHY SEEDS DON'T GROW}

READ CARTEULLY-From time immemorlal there has been more or less complaint of garden and flower seeds not growing. We are aware of the fact that there are some poor seeds sold, but we are absolutely certain that very mueh of the complaint about seeds not growing is not due to poor seeds nearly so much as it is to the seasons and more particularly. the very careless manner in which seeds are planted. The writer of this has been planting seeds from seed boxes for the last forty years, and he wants to testify here that he ha had very few fallures from the seed not growing and he attributes it very largely to the very great care taken in planting. We cannot make it too emphatic here, that if seeds are planted in season, soil well prepared and tenderly cared for when they are small and tender, that three-fourths of all the complaints of seed failures would be done away with.

\section{PREPARATION OF SOIL}

Of course the first thing to do is to get good secis. Our Seeds may be depended on; as every variety and kind that we put on the market are tested very carefully. The second thing to do and which is of very great importance, is to put the soil in proper condition. If the soil be wet and heavy it should be thoroughly drained. There is more danger of too much water than too little. Every man who wants a good garden should prepare the soil in the fall, any time before it is frozen up. Clean off all the rubbish and burn, thoroughly manure the surface and spade under. The freezing of the winter will put the soil in prime condition.

COMMON SENSE-We are certain that if gardeners and farmers will exerclse just good, ordinary common horse sense, put their ground in thorough condition, drain well, be careful not to plant too early or too late, putting in those seeds that should go in early, first, end waiting until the season warms up for the other varieties; keep the crust broken after hard beating rains, then two-thirds of the failure in seed planting will be overcome.

TOO DEFP-As a rule nearly all garden seeds, sweet corn, and especially flower seeds, are planted too deep. As a rule, seeds should not be covered more than three or four times their thickness with soil.

FLOwER SEEDS-Flower seeds, as a rule, should not be planted (except Sweet Peas, which should be planted as soon as possible), until the ground is thoroughly warmed and the heavy beating rains of spring are over. Take the utmost pains and thoroughly pulverize and make exceedingly fine the soil. As a rule, sow the smaller seeds on top of the ground and not in little furrows. Take a box of very fine soil and sift the soil over them with the hand. It will require but very little soil to do this.

FARLY PLANTING-This is another fruitful source of seeds not coming up. There are some seed that can be planted as early as you can get them in the ground, in the sprino. with perfect safety, while others must be planted much later. Smooth Peas, Radish, Lettuce, Beet and Onion Seed, may be planted quite early, while Wrinkled Peas, Beans, all kinds of Vine seed and Sweet Corn should not be planted until the danger of freezing is past, and when the ground has become well warmed up. Vine seeds should not be planted until almost the 1st of May in this Northern latitude. Beans not much before the 20 th of April.

\section{Don't Plant Sweet Corn Over 1/2 Inches Deep}

SWEET CORN-Possibly there are more failures with Sweet Corn than any other one kind of seed and for two very important reasoms. First, the Corn is planted too early, when the ground is cold and wet. Sweet Corn will not stand the rough treatment and the dampness that Field Corn will stand, because they are soft and spongy, absorb the moisture and rot. Second, Sweet Corn is almost universally planted too deep. It should not be planted, in such seasons as we have been having for two or three years, over an inch, or $11 \frac{2}{2}$ inches deep. Three or four inches, as is often planted, is entirely too deep. Of course if the ground be dry, thoroughly drained and warm, it may be planted some deeper. The early varieties, such as Corys, White Mexican and Minnesota, may be planted earlier than, the later varieties, such as Stowell's Evergreen and Country Gentleman, for they are flintier and hardier and absorb as Stow elo less moisture than the later varieties. Sweef Corn should be planter closer in hilis than have increased our yield over former years fuly ó per cent by so doing. 


\section{VEGETABLE SEEDS}

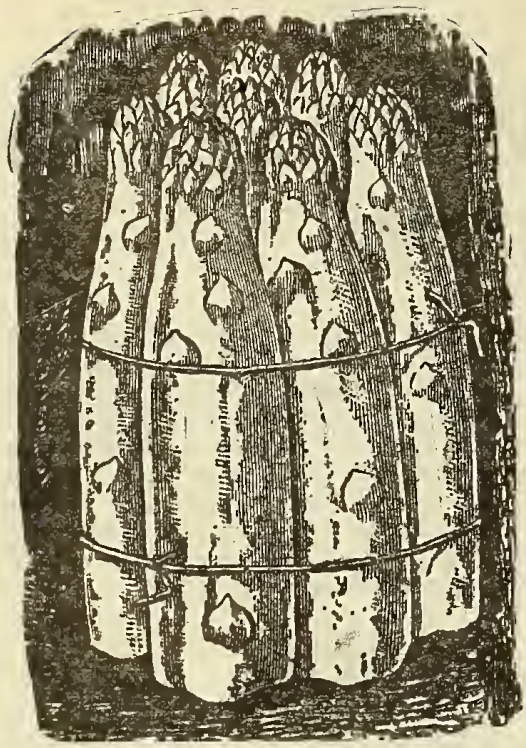

\section{ASPARAGUS}

pkt. oz. $1 / 4$ lb. $1 \mathrm{lb}$.

Barr Mammoth-Has very large tender stalks of very light color $\$ 05 \$ 10 \$ 20 \$ 60$ Conover Colossal-The most ap-

$\begin{array}{lllll}\text { proved and standard sort; large } & 05 & 10 & 15 & 50\end{array}$

Columbian Mammoth White - A

choice variety; stalles white; 55 good quality ..........................

\section{ARTICHOKE}

CULTURE-Deep rich sandy loam with plenty of well-rotted manure. Sow seeds in April and May, and when large enough, transplant into rows three to four feet apart and two feet in the rows. They reach maturity the second year. Cover with litter when cold weather commences, first tying up the leaves so that we in a dressing of manure. It is an excellent vegetable and easily grown, thriving in any situation, providing the heads are cut off and used as they get ready.

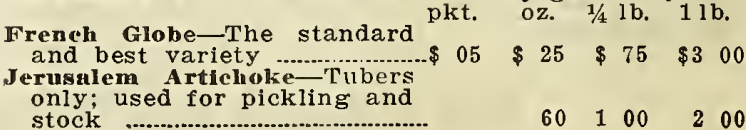

\section{BEET}

Rendy for Table Use in 40 to 60 Days.

\section{GARDEN BEETS FOR TABLE USE}

CULTURE-Sow as early in the spring as the ground can be worlied, and every two weeks fter for a succession up to the first weeks of July. For general crop sow about the middle of May. The soil should be light sandy loam, well enriched with stable manure and plowed and harrowed until very fine. Sow in drills one foot to fifteen inches apart, and when well up, thin to from four to six inches. The young beets pulled out of the rows are excellent used as Spinach.
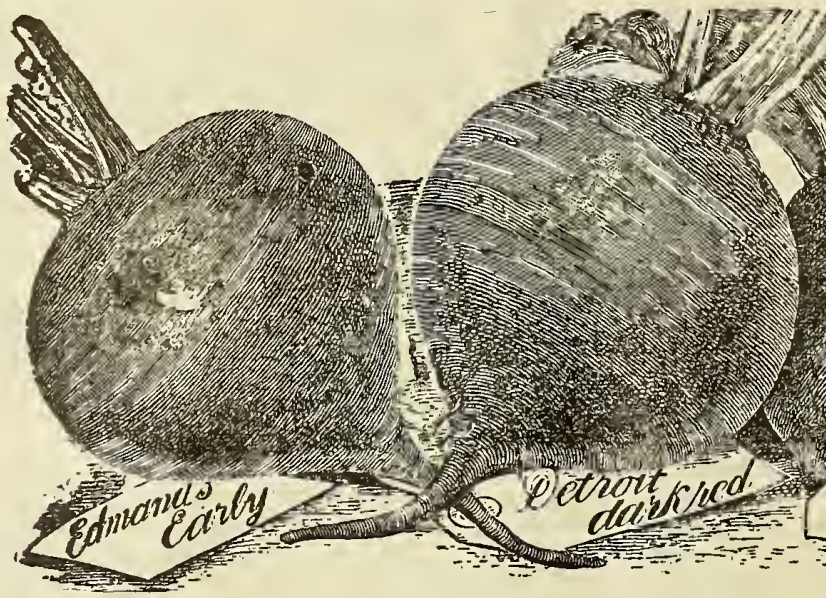

Early Model- $x$ tremely early; perfect globe, deepest blood red

Bustian-A vory early light colored turnip beet; fine marlet variety

An extra early dark blood, round, not flesh

Detredt Darix Red-Very choice deep red; fine shaped beet; see cut ..........

Dewing Early-Of fine form, flavor and good for market .......................... 05

Darly Tarnip Bagano-Grows to a large size, tops large, flesh pink, zoned

with white; very sweet

Easly Blowd Tarnip-Dark red and of fine plavor; productive, standard sort 05

Edmand Blod Turmip-A market gardener's strain of great regularity in

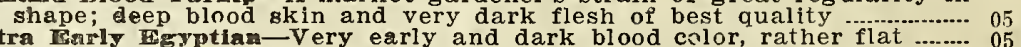

Extra Tarly Egyptian-Very early and dark blood color, rather flat ...... very best

Falf Long Hlood-Fine dark strain; distinct variety; smooth and handsome 05

Leat matra Warly Turalp-A large small top, round beet, fine strain ......... 05

Long smoeth Blood-A good late variety; dark red; tender and sweet .... 05

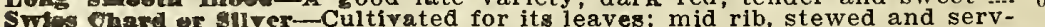

ed as asparagus, the rest served as spinach

t. $\quad 0 z .1 / 4 \mathrm{lb}$. 


\section{BEET-Mangel, Wurzel, Sugar, Etc.}

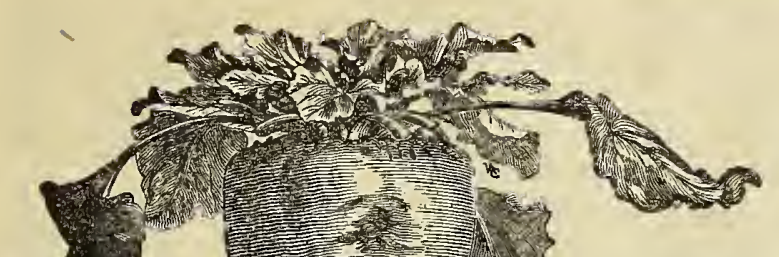

CULTURE-As all Mangels require a deep soil in order to grow well, plow and sub-soil at least a foot to eighteen inches, and apply plenty of rich stable manure) Sow in May or June, in rows eiohteen inches to two feet apart, and thin to elghteen inches in rows. Young plants may be transplanted to fill up vacancies. Sow in addition, when the plants are three to four inches high, at the rate of 200 pounds. Complete manure, 200 pounds bone flour and 400 pounds salt per acre As soon as frost occurs, dig the pounds in order to be well preserved for gradual crop. But in consumption during the of a dry, sloping situation; cover at first with a piece of canvas, and as the cold increases should be replaced by about

MA MMOTH MNG $\mathrm{RT}$ MA NGFL six inches of either salt, hay, straw, sea weed, or even corn stalks. Lest this covering be displaced by the wind, a light layer of earth is necessary So layer of earth is necessary. So

soon an this surface soil becomes frozen about six or eight inches more of earth should be placed over the entire heap. By following up this gradual process of covering, all danger of heating will be obviated, and the roots will keep in perfect order. Sow from four to five pounds per acre.

Prices for large quantities on application.

Mammoth Long Red Mungel-Wurzel-Very plat. oz. 1/4 lb. I lb large, selected straın, the largest and finest roots. The standard .....................

Long Yellow Mangel-Wurzel - Good main crop sort

Orange Globe Mangel-Wurzel-of distinct shape; one of the most productive; hardy, vigorous

Golden Tankard Mangel-Wurzel-A bright yellow; handsome and sweet, and very productive; tops small, -roots large.......

Red Globe Mangel-Wurzel-Similar to the Yellow Globe; productive

Lane's Sugar-For sugar making or stock feed

White Sugar Beet-Grows to a large size and is useful for making sugar, as well as for stock feeding

Vimorin Improved Sugar-a much inproved strain of the preceding; very valuable as a sugar-producing beet ......................

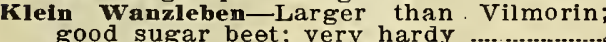

$\begin{array}{llll}05 & 05 & 10 & 35 \\ 05 & 05 & 10 & 35 \\ 05 & 05 & 10 & 35 \\ 05 & 05 & 10 & 35 \\ 05 & 05 & 10 & 35 \\ 05 & 05 & 10 & 35 \\ 05 & 05 & 10 & 35\end{array}$

$05 \quad 05 \quad 10 \quad 35$

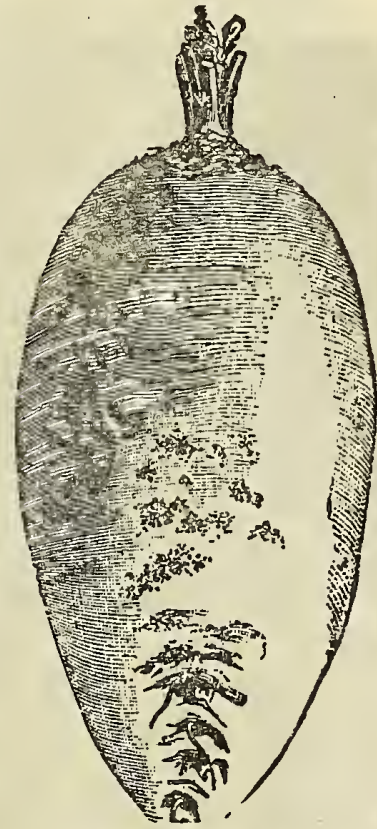

Giant feeding supar

Giant Feeding Sugr-This unites the large the 05 the greater feeding value of the Sugar Beet. The roots are always regular and uniform, broad at the top with a full and slightly tapering shoulder

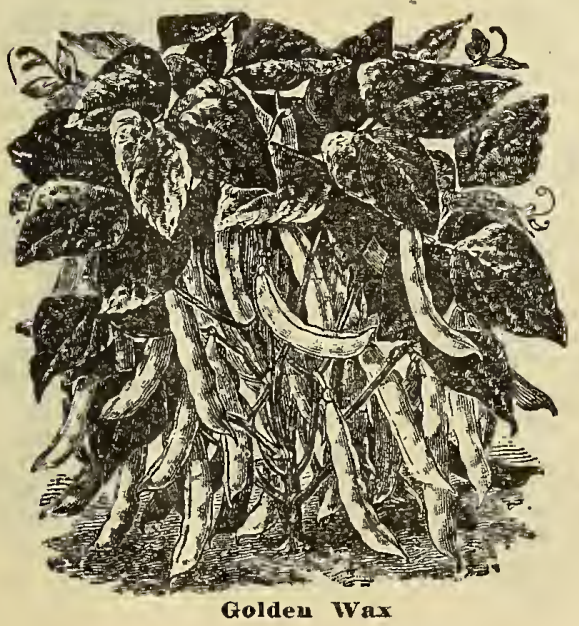

\section{BEANS}

\section{DWARF WAX BEANS}

Davis White Wax - Very hardy, productive, long pods, very handsome rustless, fine shipper, Pkt. Per lb. 15 lbs. 60 lbs, best canner; in all points the best Wax .................

Golden Wax-Best known Wax bean; very early, fine podded ..................

rerman mork and best quality .......... Black-Eyed Wax-A cross

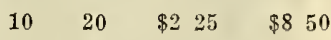
$10 \quad 20 \quad 2 \quad 25 \quad 850$ between Golden and between Golden and and very productive; yellow pods .................. $10 \quad 20 \quad 225 \quad 850$ 


\section{BEANS-Continued}

Improved Prollple Black Wax-Very early and prolific. The pods ar round, full, stringless, and of fine quality

Challenge Black Wax-An extra early strain of the Dwarf Black Wax $10 \quad 20 \quad \$ 225 \quad \$ 850$ Detrolt Wax--Very much like Golden Wax, but less liable to rust....... $10 \quad 20 \quad 2250880$ Flageolet Wax-Flat, yellow, stringless pods of great length anr breadth; exceedingly productive

Grinnell's Improved Golden JVax-Very early; round, golden pods........ Golden-Eyer Wax-Very hardy and prolific, w ith flat, yellow pods; very early and exceptionally free from rust; a very desirable and popular sort

PInk-Eyed wax - Verv fine variety, resembles Golden Wax ................. Currie's Rust-Proof Wnx-Vigorous and hardy; productive ............... Refugee wax-A perfect Refugee with long, round yellow wax pods; suitable for early or late sowing, and an immense yielder ....... remarkably free from rust

White Wax-Flat, yellow pods; very handsome, vines small .............. Yosemite Mammoth Wax-The largest pods of all the wax sorts; productive and of good quality ............................... fleshy, absolutely

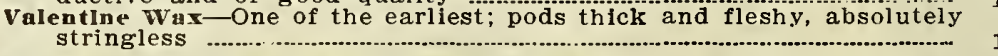

Pkt. Per lb. $15 \mathrm{lbs}, 60 \mathrm{lbs}$.

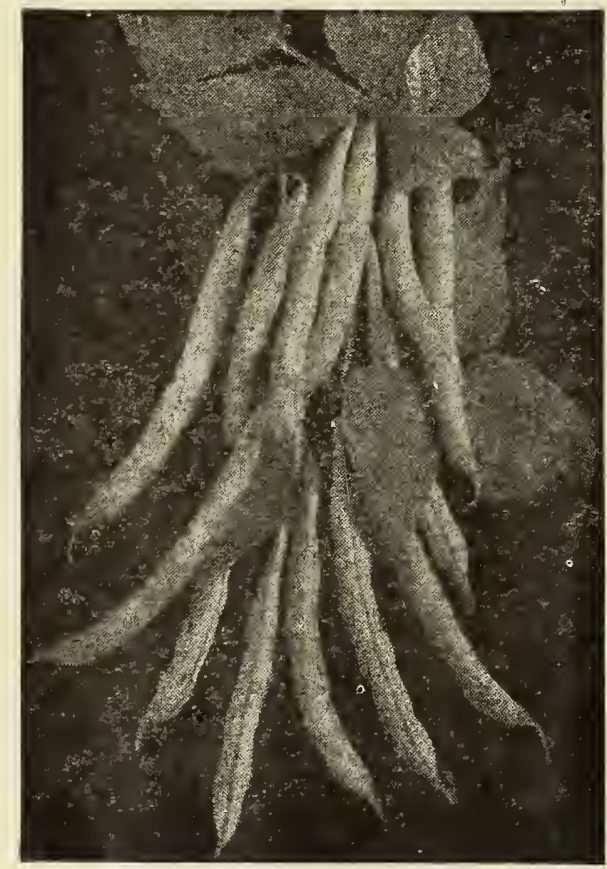

Royal Round Pod Purple Wax

\section{ROYAL RUUND POD}

This new bean, introduced by us for the first time in 1908 , promises to be a great accession to the market gardeners.

DeserIptIon-Plant large, without runners; generally drooping with fruit-laden branches, and spreading when fully grown. The season is early: the leaf is large, medium green; wide across leaflets; pods are vely round and yellow in color; very brittle; stringless; without fibre and unsurpassed in quality. Owing to its being a prolific Bean and as tender as the Crystal White Wax, it will be much in demand by the market gardeners, or those wanting a first-class, round pod, wax bean. In twenty-five years of experience as growers, we twenty-five years of experience as growers,
have never found anything to cnmparo with it.

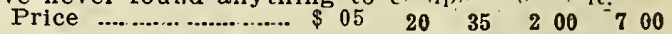
Sioux City, Iowa.

Gents: I planted this spring a row of your new Royal Purple Wax Beans. I consider it the best bean I ever ate; quality is unsurpassed; perfectly stringless; round pod, very eally
Respectfullv,

$$
\text { MRS. EVA R. CUMMINGS. }
$$

Oct. 1,1908 .

Sioux City Seed Co., Sioux City, Iowa.

Dear Sirs: I have had your new wax bean, The Royal Purple Round Pod Wax, growing on my trial ground this season and I have been very much pleased with it. It is of very high quality and has the much desired round straight fleshy pod. I believe that it will fill the same place among Wax Beans that Burpee's Stringless does among the Green Pods. You certainly have a guod thing in your bean and $I$ hope you will push it extersively Yours trulv

HENRT F'TELD SEEN CO.

By Henry Field, Pres.

\section{DWARF, OR SNAP BEAN}

Green Podded-Ready for Use In 30 to 40 Day Pkt. Lb. $15 \mathrm{lbs} 60 \mathrm{lbs}$.

$\begin{array}{rrrrrr}10 & 20 & \$ 2 & 00 & \$ 7 & 50 \\ 10 & 20 & 2 & 00 & 7 & 50 \\ 10 & 20 & 2 & 00 & 7 & 50 \\ & & & & & \\ & & & & & \\ & & & & & \\ & & & & & \\ & & & & & \\ & & & & & \\ & & & & & \\ 10 & 25 & 2 & 25 & & 850 \\ & & & & & \\ 10 & 20 & 2 & 00 & 7 & 50 \\ 10 & 20 & 2 & 00 & 7 & 50 \\ 10 & 20 & 2 & 00 & 7 & 50 \\ 10 & 20 & 2 & 00 & 7 & 50\end{array}$

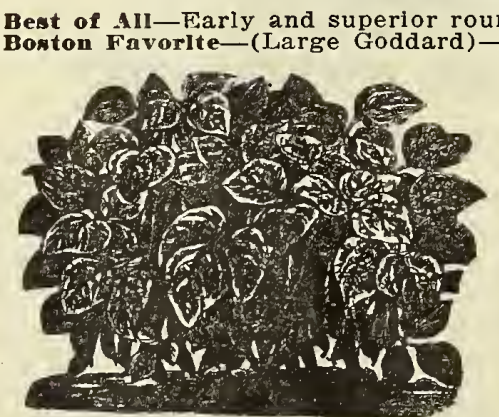

Burpee's Stringless Green Pod

und, green, fleshy pods ton Small Pea-Small, round and handsome

Burpee's Stringless Green Por This new bean produces Porsimilar to Red Valentine, but similar to Red Valentine, but develops pods to edible condition two to three days earlier than Valentine. This advances the Stringless Green Pod to the Pods are stringless-absolutely so-the pods breaking as shor and free as pipe stems; enormously productive ............................

Dwarf Hortlcultural - Late and productive; fine either shelled or green ............................... straight pods; very hardy tra Faris Red Valentine-Early strain of this popular round pod
bean, nothing superior to this in Snaps among the green podded sorts; many prefer to Wax varieties

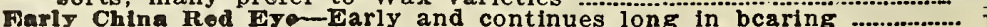




\title{
BEANS Continued
}

Round, Early Yellow Six Weeks-Resembles the Mohawk, save in color; flat pods; a popular one .......................................

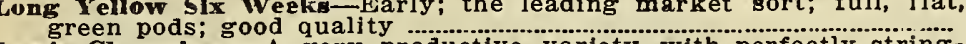
green pods; good quali productive variety, with perfectly stringless, large, green. flat pods...................................................... cefugee, or 1,000-to-1--Medium to late; very productive and tender, and largely grown for main crop; round pod ....................... but fine shape; cooks easy

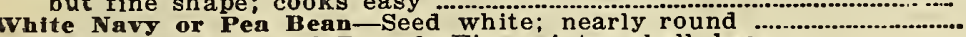

White Kidney or Royal Dwarf-Fine winter shell bean

White Valentine-Very early; tender, entirely stringless

$\begin{array}{rrrr}\text { Pkt. } & \text { Lb. } & 15 \text { lbs. } & 60 \text { lbs. } \\ 10 & 20 & \$ 200 & \$ 750 \\ 10 & 20 & 200 & 750 \\ 10 & 20 & 200 & 750 \\ 10 & 20 & 200 & 750 \\ 10 & 15 & 150 & 550 \\ 10 & 15 & 150 & 550 \\ 10 & 15 & 150 & 550 \\ 10 & 20 & 200 & 750\end{array}$

\section{DWARF LIMAS}

\author{
Ready for Use In 30 to 75 Days.
}

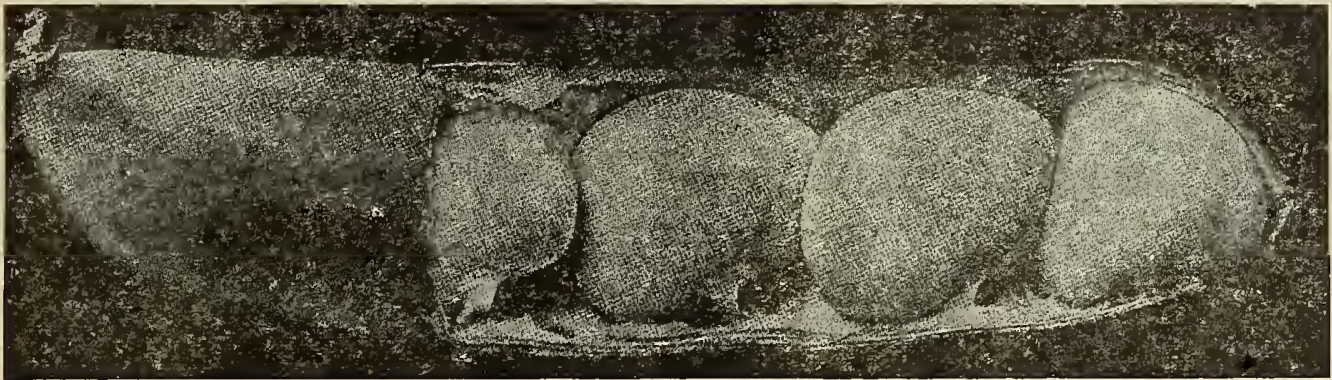

Burpee's Bush Lima.

Burpee Bush Lima-A bush form of the large Pole Lima, the beans being large and flat, like those of that variety. It is very productive and its dwarf character is well established

Henderson's Bngh

Dreer' Iush-Immensuly productive: may be used as a shell bean or snap bean; broad, flat pods

Pkt. Lb. $15 \mathrm{lbs} .60 \mathrm{lbs}$ $10 \quad 20 \quad \$ 225 \quad \$ 850$

$10 \quad 20 \quad 225 \quad 850$

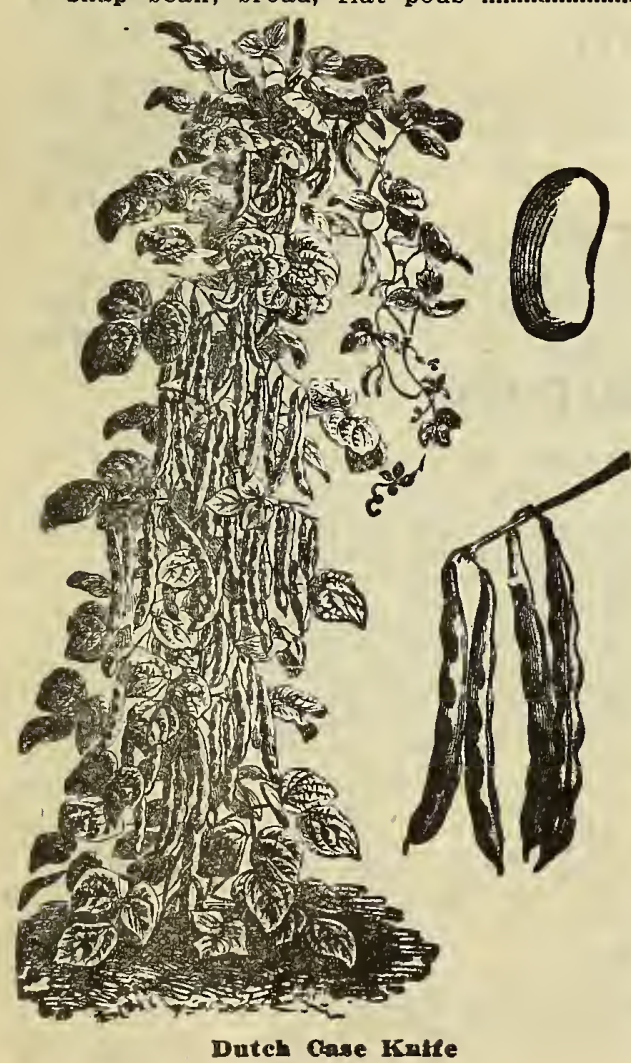

\section{POLE, OR RUNNING}

\section{Ready for Use in 70 to 20 Days.}

Golden Carmine Podded Horticultural-In this new strain we have a wonderful, robust grower. The pods are large, stringless, bright golden color when very young. As they approach full size, they are mottled and streaked with an unusually bright carmine color on the golden. which gives the pods (when ready for market) Pkt. Lb. 15 lbs. Bu. a beautiful and attractive appearance ......................

Large White Iima-Largely grown and highly esteemed ......................... Large in pod and bean; productive

Dreer Lima-Thick and of fine quality; early variet cariy Jersey Lima-A few days earlier than the

large Lima ...................... between the Horticultural and Dreer Lima it matures the Lima .........................

Hortlenitural or Speckied Cranberry - Showy, excellent either as a snap or shell bean

Speckled Cut-short or Corn Hill - Used for planting among corn, one of the

Dutch Case Knife-Pods Iong, green and flat; can be either snapped or

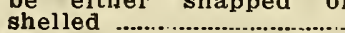

Scarlet Runner-A popular English Pole Rean; very ornamental

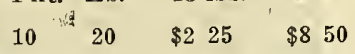

$\begin{array}{llllll}10 & 20 & 2 & 25 & 8 & 50\end{array}$

$\begin{array}{lllll}10 & 20 & 2 & 25 & 8\end{array}$

$\begin{array}{llllll}10 & 20 & 2 & 25 & 8 & 50\end{array}$

$\begin{array}{lllll}10 & 20 & 2 & 25 & 8\end{array}$

White Orease Back - Long round, stringless pod; fleshy and tender ......... 


\section{BEANS - Continued}

White Dutch Rumner-Same habit as the Scarlet Runner; flowers

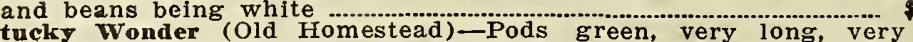
Kentucky Wonder (Old Homestead)-Pods green, very long, very Golden Andalusia (New)-Most productive of all the pole varieties; beans pure white, round .......................................................... Mont d'Or or Golden Cluster-Early, productive; golden wax pods six to eight inches long

Lazy. White-Great favorite; pod from four to six inches long, stringless, rich, buttery flavor; beans are white and make a fine shell bean; pods remain green and tender long

\section{Borage}

Pkt. Lb. 15 lbs. $60 \mathrm{lbs}$

$10 \quad 20 \quad \$ 2 \quad 25 \quad \$ 850$

The young leaves of this annual, which smell somewhat like a cucumber, are used as a salad or boiled like spinach. Should be sown at intervals, as the leaves are palatable only when young. Sow in the spring in light soil and transplant in shallow drills, a foot apart, when of about six weeks' growth.

Horase

\section{Broccoli}

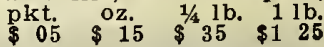

CW-Sow early sorts as soon as the ground can be worked in the spring, in shallow drills, drawn three or four inches apart. Plant out two feet apart each way when the plants are about four inches high. Cultivate the same as cabbage, in rich soil. Use the same remedy for insect attacks as are recommended for cabbage. The following are sorts best adapted to this climate, and the only ones which succeed generally; they are excellent and deserve much wider culture than is usual in this country.

Early Whlte Cape-Best flavor; very hardy; small pkt. oz. 1/4 Ib. $1 \mathrm{lb}$

Eariy White Cape-Best flavor:

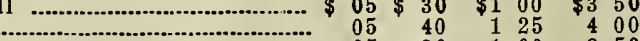

Carly Purple Cape-The very best; Iarge................................................................

\section{Brussels Sprouts}

CULTURE-Sow in May in the same manner as Cauliflower and transplant in July, one foot apart, in the rows, which should be one and one-half feet apart. In gardens, both large and small, Brussels Sprouts are, without exception, the very best winter vegetable that can be grown. The real sprout is not much larger than a marble, and as firm and hard almost as the stalk i.tself. These are the sort which cooks prefer. They strip off the outer covering, cook them whole, and serve them up artistically in that fashion. When cooked through and no more, such Sprouts melt in the mouth like the tenderest Cauliflower, and are equally as good. Improved Hulf Dwarf-The very best and surest strains ........................ $\$ 05 \quad \$ 20 \quad \$ 60 \quad \$ 200$ Improved Dwarf-Compact heads of fine quality............................................. 05

\section{Chervil}

CULTURE-Cultivate and use the curled variety of Chervil, like Parsley. Sow at any time in the spring, in shallow drills, one foot apart, in well prepared orround. The seed of the Tuberous Chervil should be sown in August or September, and treated like the Carrot.

Curled-The leaves of this are used for flavoring soups and stews and for garnishing, same as Parsley. pkt. oz. $1 / 4 \mathrm{lb}$. $1 \mathrm{lb}$

\section{Chicory}

Chicory is cultivated chiefly for its roots, which are dried and used as a substitute or llavoring ingredient for coffee. The leaves, when blanched, are also esteemed as a salad.

Cultivate as recommended for Carrots.
Long Rootel Madgeburg-Roots are the Chicory

$\begin{array}{lllll}\text { pkt. } & \text { oz. } & 1 / 4 & 1 \mathrm{~b} . & 11 \mathrm{~b} . \\ \$ 05 & \$ 10 & \$ 25 & \$ 75\end{array}$

\section{Garden Carrots}

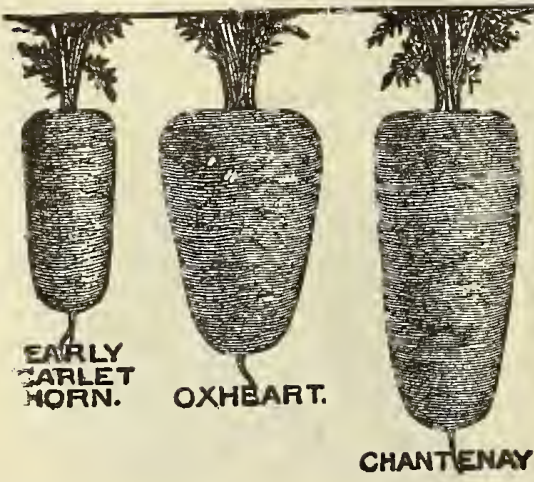

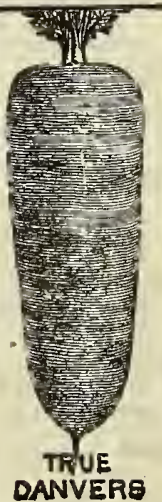

Regdy for Table in 60 to 80 Days Early Horn-Very early
variety, excellent flavor r.......

French Early Foreing-

Tender and fine; best for early and late crops and frames

Half-Long Stump Rooted, Chantenay StrainStyle of Nantes; has broader shoulder

Half-Long Stump Hooted Carentan-Corteless; flesh $r e d$, of fine quality

Half - Lone Danvers-

Thick, of good quality and exceedingly proand exceedingly pro-

Large Whlte Belgian-Very large; excellent stock Carrot

Larse Yellow Belgian-Very large; excellent stock Carrot ................................. introduction either for family or market; most beaultul snape and ricu orange color

salnt Vallery-Very choice, good flavored

$\begin{array}{llll}05 & 10 & 25 & 80 \\ 05 & 10 & 25 & 80 \\ & \cdot & & \\ 05 & 10 & 25 & 80 \\ & & & \\ 05 & 10 & 25 & 80 \\ & & & \\ 05 & 10 & 25 & 80 \\ 05 & 10 & 25 & 80 \\ & & & - \\ 05 & 10 & 25 & 80 \\ 05 & 10 & 25 & 80\end{array}$




\section{CABBAGE}

Ready for Use iu 75 to 210 Days.

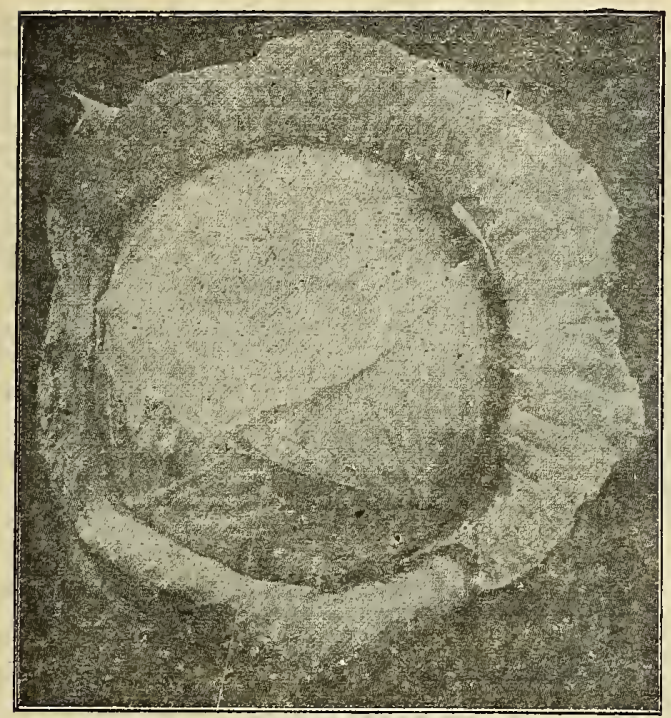

Hollander

Expres -The earliest of all; small, solid heads; fine forcing

Etampes solid

All Head-The very best second early, fine flat heads, very hard, solid. Early Jersey Wukeficld-Well-known and most valuable for early.... Early Winuingstadt-A standard second-early variety; pointed heads .... Early Dwarf Savoy-The earliest Savoy variety; distinct and good ........ Early Flat Dutch-A remarkably fine strain; a sure header; the head weighing from ten to twelve pounds, most valuable for market

Henderson's Early Summer-A superior second-early sort, produces large and solid heads of fine quality

Selected All Seasuns-One of the finest for second-early or late, growing

to a large size, quickly and surely; the true sure header...................

Henderson Succession-An excellent second early or late sort on the style of All Seasons

Fottlep Brunswick-Good, solid heads, either for second-early or late.....

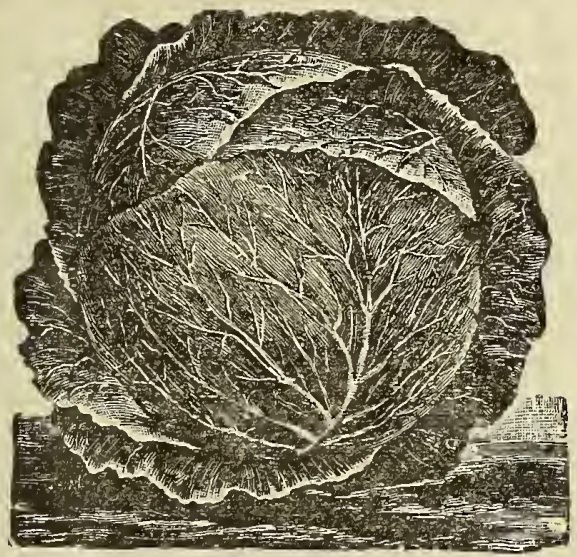

head, fine for kraut.

head, fine for kraut..... - Also a valuable main

crop Ram. Rock Red-Very

large, solid, red heads,

the finest strain of red

NEST STIRAINS OF AMERICAN T.ONG ISLAND GLOWN CABBAGE SEWD. MAIRET GARDENSA. DEPTID ON PLANTS FROM - Soil for Cabbage should ald with good in conditiou to transplant to cold frames, whered, taking care, in the first leaves. Transplant in spring as soon as the ground can be worked, setting 作 grower says: "Take one ounce of saltdissolve it in twelve quarts of plants well. Cne application is suiffithe stuff is washed off by To prevent the turnip flea from attacking the young plants, sift fine air-slacked lime or tobacco dust over then pear above the ground.
pkt. oz. $1 / 41 \mathrm{~b}$. $11 \mathrm{~b}$.

$05 \$ 15 \$ 50 \approx \$ 1 \overline{90}$ $\begin{array}{llll}05 & 15 & 50 & 190\end{array}$ $\begin{array}{llll}05 & 15 & 50 & 1 \\ 05 & 150\end{array}$ $05-15$ $\begin{array}{llll}05 & 15 & 50 & 190 \\ & & & 150\end{array}$ $\begin{array}{llll}05 & 15 & 50 & 190\end{array}$ $\begin{array}{llll}05 & 15 & 50 & 190\end{array}$ $\begin{array}{llll}05 & 15 & 50 & 190\end{array}$ $\begin{array}{lllll}05 & 15 & 50 & 1 & 90\end{array}$ $\begin{array}{llll}05 & 15 & 50 & 190\end{array}$ $\begin{array}{llll}05 & 15 & 50 & 190\end{array}$ $\begin{array}{lllll}05 & 15 & 50 & 1 & 90\end{array}$ \begin{tabular}{l}
$15 \quad 50 \quad 190$ \\
\hline
\end{tabular}

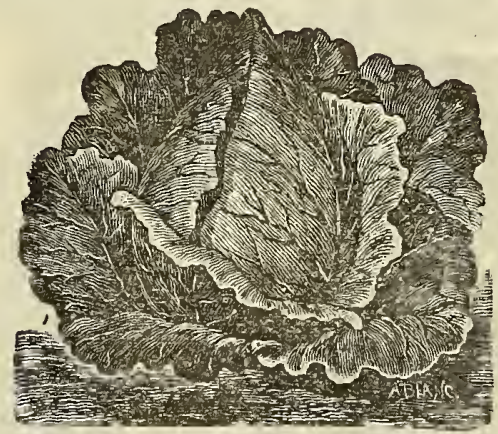

Eaxly Jersey Wakefield

Premium Late Flat Dutch

Stonemason Drumhead-A standard winter cabbage for main

$05 \quad 15$

Hollander-One of the hardiest in cultivation; quite a distinct variety; medium size, round, very solid, extra keeper, best of quality-our seed is from a very rcliable Danish grower.

Marblehead Mammoth Drumbend-The largest Cabbage known, weighing in some instances over fifty pounds; under good cultivation acres have been grown where the heads would average thirty pounds each Genuine Sure-Head-Never fails to make a large, fine head, with few outer leaves; fine grower; flat Irumhead.

St. Lowis Late Market Garden-A very fine late first cabbage; a very sure header, especially fine for Southern trade
05

05 


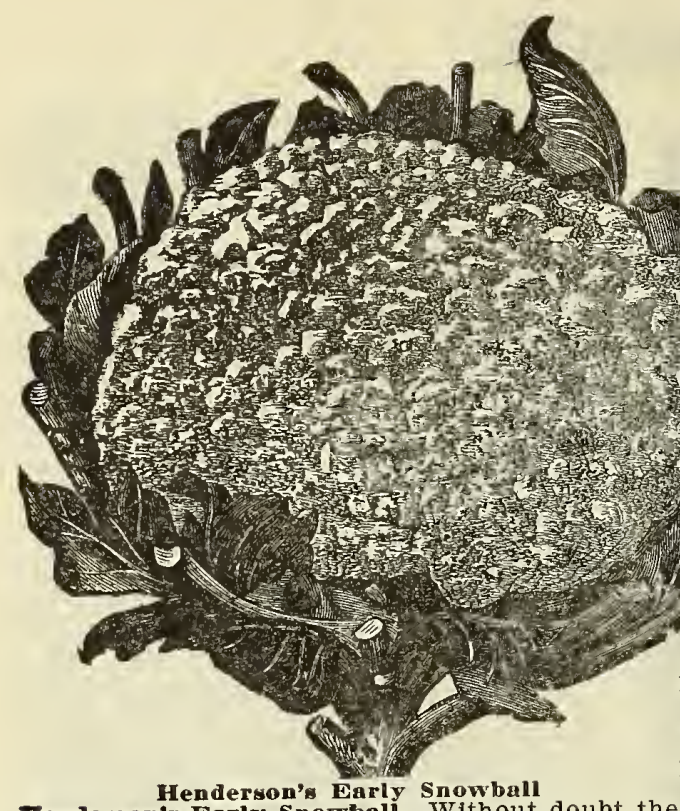

Henderson' Early Snowball

\section{GAULIFLOWER,}

\section{Ready for Use in Do to 120 Days.}

CULTURE-This is the same as for Cabbage, except that extra manure and plenty of water will pay upon this. If the soil be dry, water frequently, and if the plants could have a heavy mulch of hay or straw, it would keep the soll moist, and the plants would not suffer from drouth. The early kinds should be strong enough to plant out not later than the midale or April; the late kinds may be planted out same time as for Cabbage. To destroy the Cauliflower maggot, it is recommended to take one ounce of sulphuret of potassium and dissolve it in one gallon of water. Heat the large spoon, or something that will hold the 100 th part of a gallon, and pour the liquid against the stalk of the plant just above the ground.

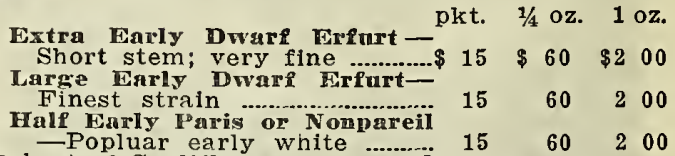
is of the very finest strain; grown specially for us in Denmarle, and sure to make a fine solid head; don't buy cheap Cauliflower seed; there is no soed in which quality counts so much

$\begin{array}{lll}70 & 2 & 60\end{array}$

\section{CELERY}

CULTURE-Sow the seed in a light, rich dry border as early as the ground can be worked, in drills eight or ten inches apart, and cover the seeds about a quarter of an inch deep, rolling or treading them in if the ground be dry. When fairly out of the seed leaf they may be trans-

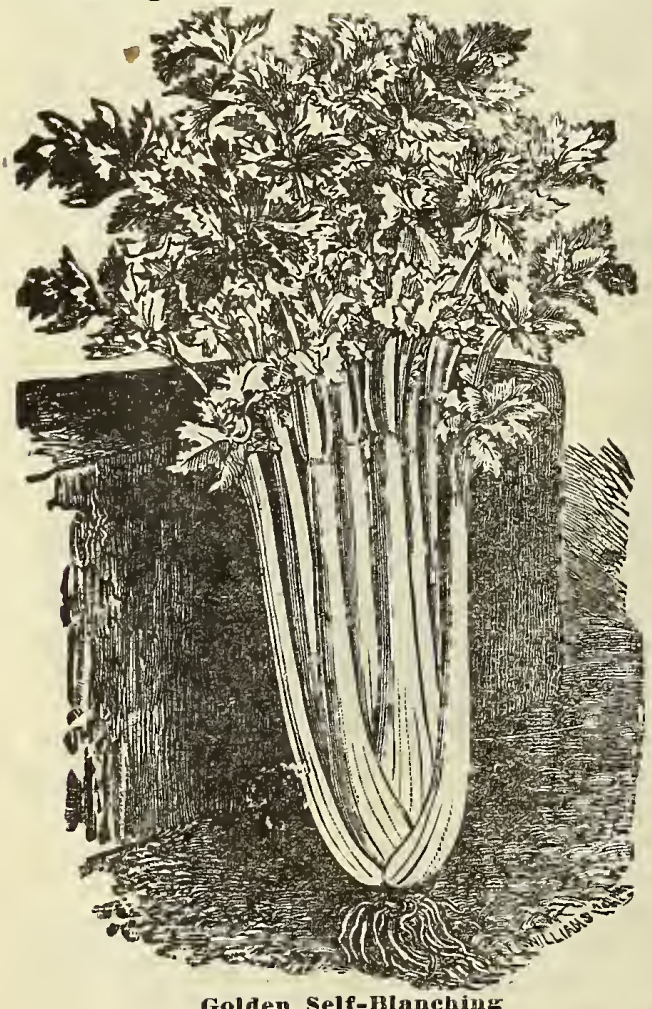

Golden Self-Blanching planted to another bed, or they may be thinned out in beds or trenches. The bed should be kept well weeded, and an occasional soaking with water in dry weather will do the plants good. Early in July at the north, a month or six weeks later in the southern states, is the proper time to set the plants out in beds or trenches. Press the soil firmly against the roots. In the garden the better way is to set the plants in shallow trenches-we say shallow, for it is obviously a bad plan to remove all the good soll (as must be done in a deep trench) and put the plants in that which is poor. The plants may be set in a single row in a narrow trench, or the trench may be made into a bed wide enough to hold two, three or four rows, and in case the plants are in a compact form, to be covered for the winter where they grow When grown in beds this way, the rows should be one foot apart, and the plants about eiglit inclies apart in the rows. The bed should be made very rich with thoroughly decomposed manure. The plants will need to be earthed up two or three times, and in doing this care should be taken not to let the earth get into should be taken not to let the earth get into plants are set on the surface in rows four feet apart when the celery is to be earthed up in the field for early use, and two feet apart when the plants are to be taken up and blanched in the cellar for wiliter use. The plants are set six inches apart in rows. If not grown in beds the best way to store is to dig trenches in a wel]-drained spot in the open ground, one foot wide drine so wide and of a depth a few inches less than lifted helght of the celery. The plants are then and set rlose together until the whole quantity is stored. The edges of the trench should be made sloping from the tops of the plants. When severe cold weather comes on, cover gradually with leaves, hay or straw and place boards on top. In sich a trench the stalks will blanch ing the winter for use or sale as required. 


\section{CELERY - Continued}

Imprered White Plume-Naturally white or light follage; requires but ilttie banking up to blanch; very early and extensively grown for market Plume, except that it is golden yellow where the Plume is white....

Giant Paseal-An easily blanched and fine keeping large sort, of excellent flavor; superior for late use

Pink Plume-A strong, healthy, compact grower, with no tendency to rust: very solid, crisp, extra eariy and a long keeper ..........................

Giant white Solld-Large, round, crisp and solid; the ol a well-known variety

Celeriac or Iarge Smooth Pragae-An improved form of the rooted celery, roots smooth and round

Goiden Heart Dwarf-A very popular and distinct variety; in habit of growth it resembies the Half Dwarf white sorts, except that when blanched, the heart, which is large and full, is of a waxy golden yellow

Celerg for Flavor-Per pound, $20 \mathrm{c}$; per five pounds, $75 \mathrm{c}$.

kt. oz. 1/4 1b. $1 \mathrm{tb}$

$05 \$ 20 \$ 50 \quad \$ 175$

$\begin{array}{llll}05 & 30 & 75 & 2.75\end{array}$

$05 \quad 20 \quad 50 \quad 150$

$\begin{array}{lllll}05 & 20 & 50 & 175\end{array}$

$\begin{array}{lllll}05 & 20 & 50 & 150\end{array}$

$05 \quad 11 \quad 35 \quad 125$

$\begin{array}{lllll}03 & 20 & 50 & 1 & 75\end{array}$

\section{Corn Salad, or Fetticus}

CULTURE-Sow during August or early in September, in drilis a quarter of an inch deep and six inches apart. If the weather is dry when the seed is sown, tread it in slightiy to insure germination. Keep down weeds with hoe. Just before winter cover thinly with straw or leaves.

Large Seeded-The best variety for family use; makes delisious salad; pkt. oz. $1 / 61 \mathrm{~b}$. $1 \mathrm{lb}$.

used during the winter as substitute for Lettuce ................................. \$05 $\$ 10 \$ 20 \$ 60$

\section{Collards}

CULTURE--Sow seed as for Cabbage in June, Juiy and August for succession; transpiant when one month old in rows a foot apart each way and hoe often.

Georgia Grown or Southern

$\$ 05 \$ 10 \$ 30 \$ \$ 5$

\section{Cress}

CULTURE-Sow thickly in shallow drilis every two or three weeks. It is useful not only for salad, but for the breakfast table and for garnishing. Water Cress should be sown in damp soil, or if a stream of water can be utilized, it would be much finer. It will aiso thrive in damp hot-beds. Rishtiy managed its culture is very profitable. To obtain early saiad, it is a good plan to sow with the Water Cress seed a strip four inches wide on the outer margili of a hot-bed, inside the frame (where it is always cool). This will be found a satisfactory method of obtaining it eariy.

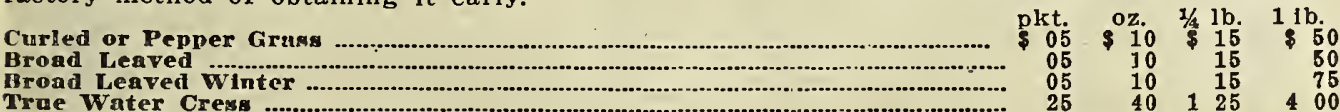

\section{CORN, SWEET AND FIELD \\ Pedigreed Seed Corn vs. Elevator Seed Corn}

In Seed Corn, as in everything good, there is much hypocrisy and deceit-in other worde, plain lying, so that the farmer hardiy knows whom to trust or where to get good seed. Many seedsmen, mushroom lellows, making high olaims, hoping to get rich in a year or two, are sending out only scoop shovel or elevator corn. This has a tendency to bring the whole seed corn business into disrepute. We don't ask you to take our word for what we say of our method of growing, handilng and caring for seed corn, but we do ask you in good ralth to come and see sa, go through our corn drying cribs, look our corn over, watch us closely butt and tip the ears, see that in many cases we reject one-third to one-haif the corn, examine the whole precess from the fleld to the bag or crate, and if you are not satisfled that our geed corn is all, even more, than we claim for it, we will pay all your expenses coming and going and at the city. Possibly you cannot come yourself. Have you not a friend whom you cen send-someone living in or near our city? Send him; we will stand or fall by his report.

\section{Ear Seed Corn}

For the past two or three seasons there has been quite a large demsnd made upon us for seed corn in the ear. We have selected from our 6,000-acre plant some very cholce stocks of sil the varieties we catalogue, and we shall be prepared to fill orders in 70-pound crates. We all the varieties we catalogue, and we shali be prepared to fillorders in 70-pound crates. We have selected these ears from our stock that show high vitality and pure breeding, and any farmer desiring to buy corn on the ear can get no better stocks from any part of the United the butt and tip of the corn should be shelled off and rejected. These ears will be found so perfect that there will be but little loss on that account, and while we recognize the impossibility to furnish to our trade every ear an ideal ear, we have undertaken to put up a stock that, used by the farmer, will bring to us additional trade in the years that are to come. In the oiden times it was the custom of the family to card the wool, to spin the yarn, to weave the fabric to make the garment all in the same family, and all done by one and the same person. That time is That time is nast, and today is a day of specialists. One man can breed hich types of corn to better advantage and at a very great saving of expense for the coinmunity than each member of the communtty can do for himself. It shall be our honest endeavor, as long as we are permitted to continue the seed busin $3 s s$ here, to make this department of our work a benefit to the cultural district surrounding us. We realize what it will mean if by honest endeavor we can help to add ten or twenty per cent to the average yield of the corn cron of the Northwest. We urge upon our farmers not to plant too late varieties of corn. The market reports for the last four years indicate that the corn in our latitude has falled to make grade, and this is due largely to importing seed stocks from the South. 


\section{SWEET OR SUGAR CORN}

Market gardeners and private owners will do well to consider that our Northern grown seed will give them earller corn than will seed of the same varieties grown farther south. Our seed Is thoroughly tested before it leaves our hands.

DON'T PLANT SWEET CORN DEEP.

Sweet Corn should not be planted over one inch deep; most people plant two or three inches deep-most sure to rot. Also do not plant too early. Not as early aş field corn.

White Mexican Do you know the marvelous sweetness of the old Black Mexisomething finer in every way, superior like its taste, but dislike its color. Well, we have Minnesota, earller than the cory. It was ready for table use this year in 55 days. Originated in Ft. Dodge, Ia. Was placed in our hands for trial and development. We know of nothing its equal for the market gardener. If you want the finest market gardener's corn known, plant White Mexican.

"I planted the White Mexican Sweet Corn you sent me. I have been planting sweet corn for 25 to 30 years. This White Mexican is superior to any extra early sweet corn I ever saw. Was ready to eat 58 days from planting." $H$. B. Smith, Odebolt, Iowa. corn planted your White Mexican this season, at the same time I planted extra early sweet corn from an eastern seed house. I found the White Mexican earlier and superior in every

way. It's the finest early corn I ever had." ago in a small way for a trial. Now our market gardeners want nothing else for their early and extra early crop. It's the earliest of all; fine looking ear and as sweet as Evergreen. Book us for 14 bushels."

\section{EXTRA EARLY VARIETIES \\ From 55 to 65 Days}

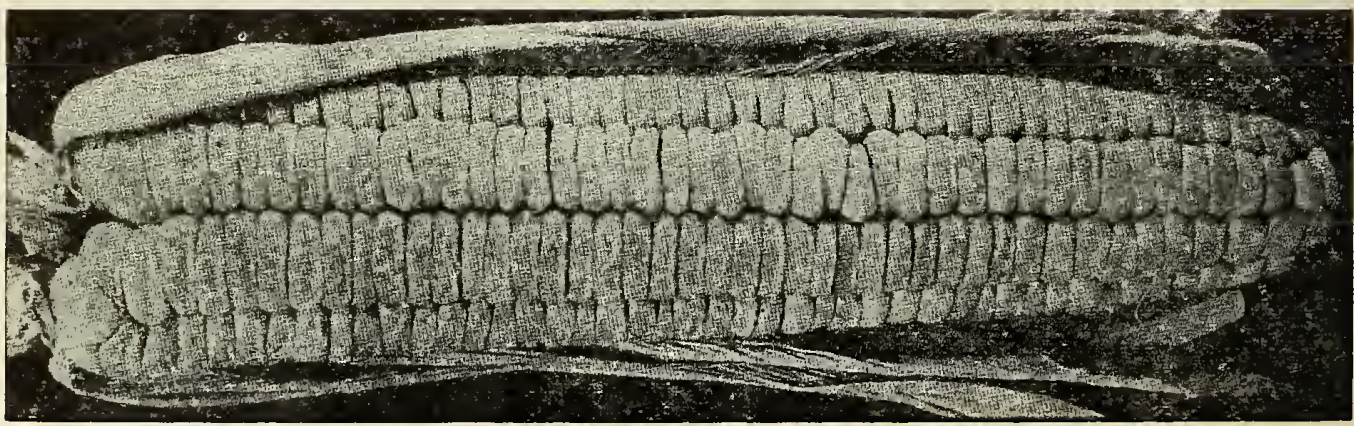

GOLDEN BANTAM Golden Bantam-Of extreme hardiness; can be planted earlier than any
other true sweet corn, and will produce the earliest supply of ears for the table. Extra fine in quality........................ $10 \quad \$ 0 \quad 15 \quad \$ 160 \quad \$ 600$

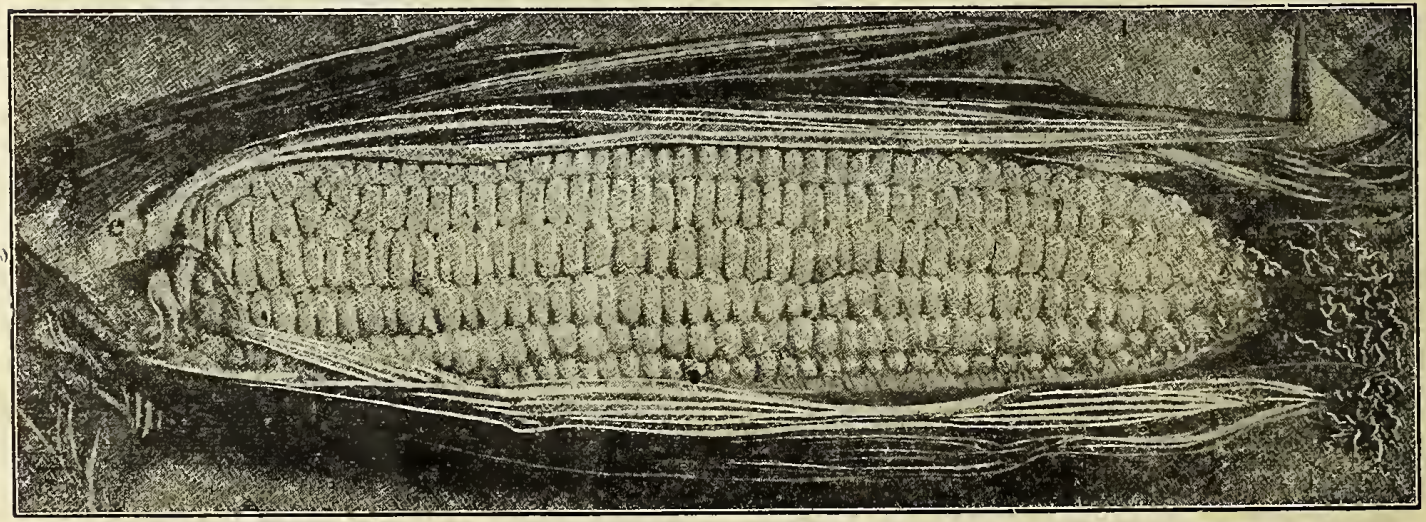

WHITE MEXICAN

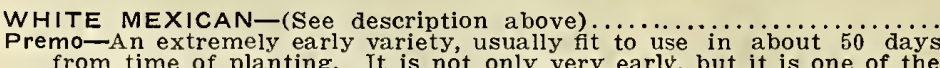

Pkt. Lb. $\quad 15$ lbs. 50 lbs.

from time of planting. It is not only very early, but it is one of the

sweetest and best. This variety combines all the good qualities of

the later sorts, is much hardier, and may be planted some days ear-
lier without danger of rotting. It is a vigorous grower, stalks about

lier without danger of rotting. It is a vigorous grower, stalks about

$10 \quad 15 \quad 140 \quad 450$




\section{CORN-- Continued}

Peep of Day-This most valuable sort is of Minnescta origin, and is not only early, but one of the best. The stalks grow from 3 to 4 feet high. Ears Pkt. Lb. 15 lbs. 50 lbs.

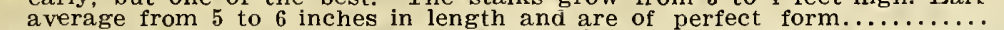
Early Cory, Red Cob-A new early variety, with good sized ears and large

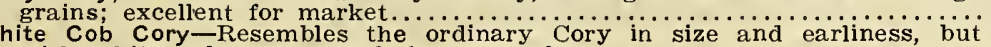
hite Cob Cory-Resembles the ordinary Cory in size and earliness, but Mammoth White Cory-Largest extra early corn known, fine quality, ${ }_{12}-$

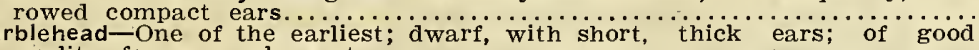

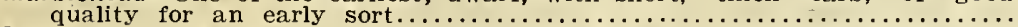

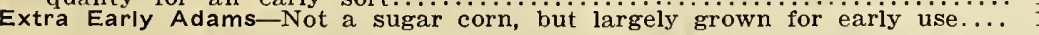

\begin{tabular}{|c|c|c|c|}
\hline $\begin{array}{c}\text { Pkt. } \\
10\end{array}$ & $\begin{array}{l}\text { Lb. } \\
15\end{array}$ & $\begin{array}{c}15 \text { lbs. } \\
135\end{array}$ & $\begin{array}{l}50 \text { lbs. } \\
550\end{array}$ \\
\hline 10 & 15 & 130 & 500 \\
\hline 10 & 15 & 130 & 500 \\
\hline 10 & 15 & 130 & 500 \\
\hline $\begin{array}{l}10 \\
10\end{array}$ & $\begin{array}{l}15 \\
15\end{array}$ & $\begin{array}{ll}1 & 30 \\
1 & 30\end{array}$ & $\begin{array}{ll}\mathbf{5} & 00 \\
\mathbf{5} & 00\end{array}$ \\
\hline
\end{tabular}

\section{SECOND EARLY OR INTERMEDIATE}

\section{From 65 to 80 Days}

Minnesota-Nearly as early as Marblehead; dwarf growth; standard ....... 10

Perry Hybrid-Very early and of large size; most valuable for market.........

Shaker Early-Very large, white grain and quite evrly $\ldots \ldots \ldots \ldots \ldots \ldots \ldots \ldots 10$

Early Crosby-Matures after the Minnesota; fair sized ears of good quality.. 10

Early Adams-Not a sugar corn, but grown exten sively all over the coun-

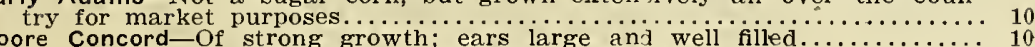

Early champion-A new and very desirable sort; e irs nearly as large a. Evergreen; pure white; only a few days later than Minnesota; very fine

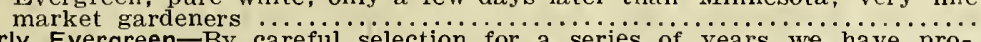
Early Evergreen-By careful selection for a series of years we have produced an early strain of this corn, earlier by 6 to 8 days ............

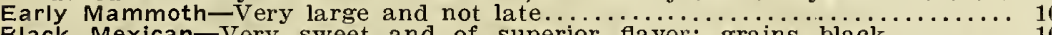

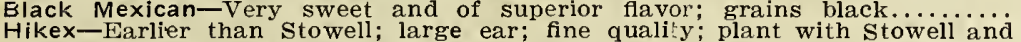

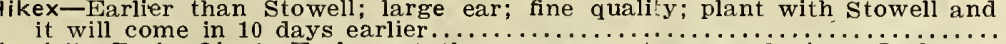

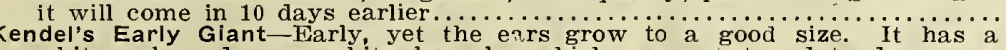
white cob and pure white kernels, which are sweet and tender....... 10

\begin{tabular}{|c|c|c|}
\hline $\begin{array}{l}\text { Lb. } \\
15 \\
15 \\
15 \\
15\end{array}$ & $\begin{array}{rc}15 & 1 b s . \\
1 & 30 \\
1 & 30 \\
1 & 30 \\
1 & 30\end{array}$ & $\begin{array}{rrr}50 & \text { lbs. } \\
5 & 00 \\
5 & 00 \\
5 & 00 \\
5 & 00\end{array}$ \\
\hline $\begin{array}{l}15 \\
15\end{array}$ & $\begin{array}{ll}1 & 30 \\
1 & 30\end{array}$ & $\begin{array}{ll}5 & 00 \\
5 & 00\end{array}$ \\
\hline 15 & 130 & 500 \\
\hline $\begin{array}{l}15 \\
15 \\
15\end{array}$ & $\begin{array}{ll}1 & 30 \\
1 & 30 \\
1 & 30\end{array}$ & $\begin{array}{ll}5 & 00 \\
5 & 00 \\
5 & 00\end{array}$ \\
\hline 15 & 130 & 500 \\
\hline 15 & 130 & 500 \\
\hline
\end{tabular}

\section{GENERAL CROP OR LATE VARIETIES}

From 85 to 90 Days

Old Colony-A very good late variety of very rich, sweet flavor; ears bear 16 to 20 rows of kernels, and are very heavy and solid ............. 10 Stowell Evergreen-Remains a long time, and is highly prized; one of the

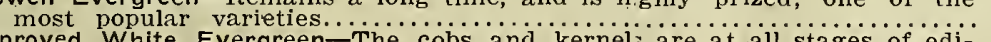

Improved White Evergreen-The cobs and kernel are a al stages of ed bility beautifully white. The getting rid of the amber tint so promigreen is a great gain, as it fits this variety for extensive use in canneries

Zigzag Evergreen-A cross between Country Gent and Evergreen. It has the very high quality of the Country Gent with almost the size of the the very high quality of the country Gent with almost the size of the

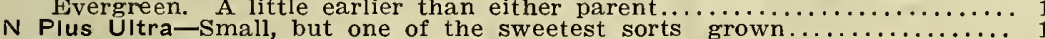

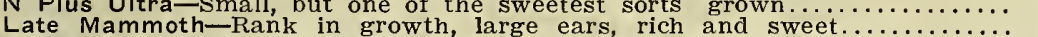
Late Mammoth-Rank in growth, large ears, rich and sweet............. Country Gentleman-Same as Ne Plus Uitra, but with large ears of delicious

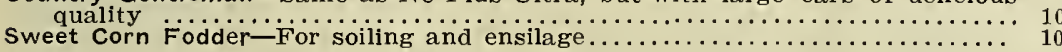

\section{FIELD CORN, EARLY VARIETIES}

Minnesota King-Ears 7 to 8 inches, 85 days. A famous half dent, 8-rowed

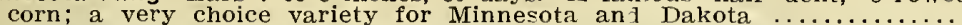
Squaw Corn-Ears 10 to 12 inches; 75 days Has a many colors of kernels as Jacob's coat-white, yellow, red and black; a very fine variety.............

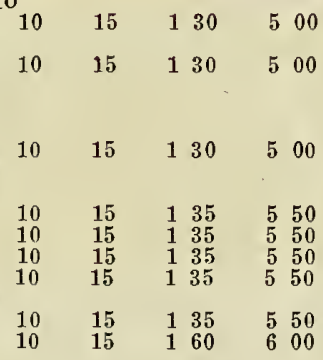

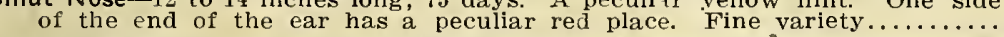

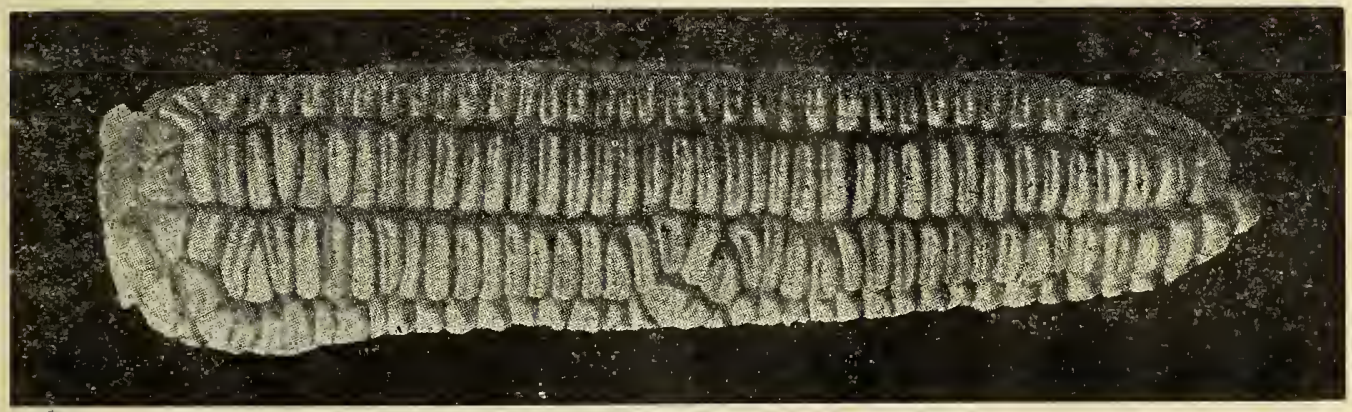

MINNESOTA KING

Triple Income-Ears 6 to 8 inches; 80 to 85 days. A white capped yellow to very best corn in existence. Will shell 64 to

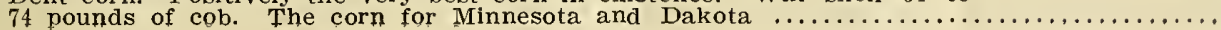




\section{CORN -- Coutinued}

Improved Yellow Fllnt-Eighty-five day corn; a very good corn for the far

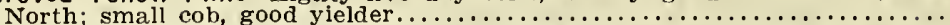

WIsconsin White Dent-Ears 8 to 9 inches; 90 days. Resembles the Silver Mine; beautiful clear dented corn, long kernel, small cob; finest white

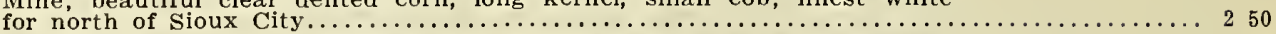

White Flint (Old Hominy)-Has large silver white kernels, a very large ear,

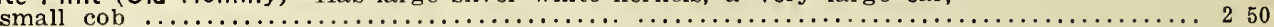

White Fllnt-Ears 12 to 15 inches; 75 days. A very long eared flint corn,

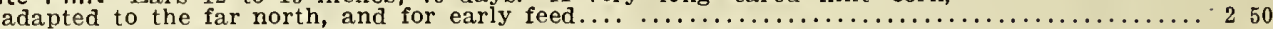

Mercer (Extra early yellow fiint)-prolific, good sized ear and small cob. Has been grown in Northern Minnesota and North Dakota for the past

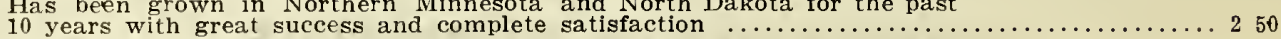

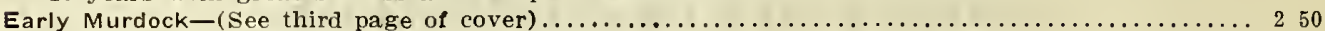

Pride of the North-Ripens in about 85 days; yellow Dent; one of the best

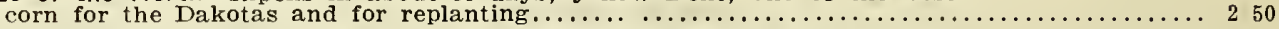

Duly's Hybrid-Ripens in 90 days; (see fuller description on next page) ................. 50

Improved Calico-The old-fashioned striped calico corn has always been popular as a feeding corn and we have had so much inquiry for a good
strain of it that we grew a field of it this year and will offer it for sale. Strain of it that we grew a field of it this year and will offer it for sale.
The ears run 10 to 11 inches long, that is the best ones, very deep grains and heavy. Color a combination of red and yellow in stripes. The grain

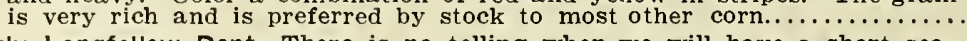

Early Longfellow Dent-There is no telling when we will have a short season and early killing frost in the fall, and in such a case farmers who have their fields planted with an early maturing variety are truly forhave their fhelds planted with an early maturing variety are truly forthey are too small and "nubby," but this new variety is of unusual they are too small and "nubby, but this new variety is of unusual length, 12 to 15 inches. Its peculiar shape, which is different from any
other sort, suggests the name. It matures fully as early as Pride of other sort, suggests the name. It matures fully as early as Pride of
the North, is double the size and yields a far greater crop, which is ripe and hard before there is a thought of frost, thus making a variety that it will pay to "tie to." Grain is not as deep as some of our other varieties, but it is the corn of corns for selling on the market, as a wagon load of it is as pretty as a picture. We recommend it highly to customers in Northern Iowa, Minnesota, the Dakotas and our northern states

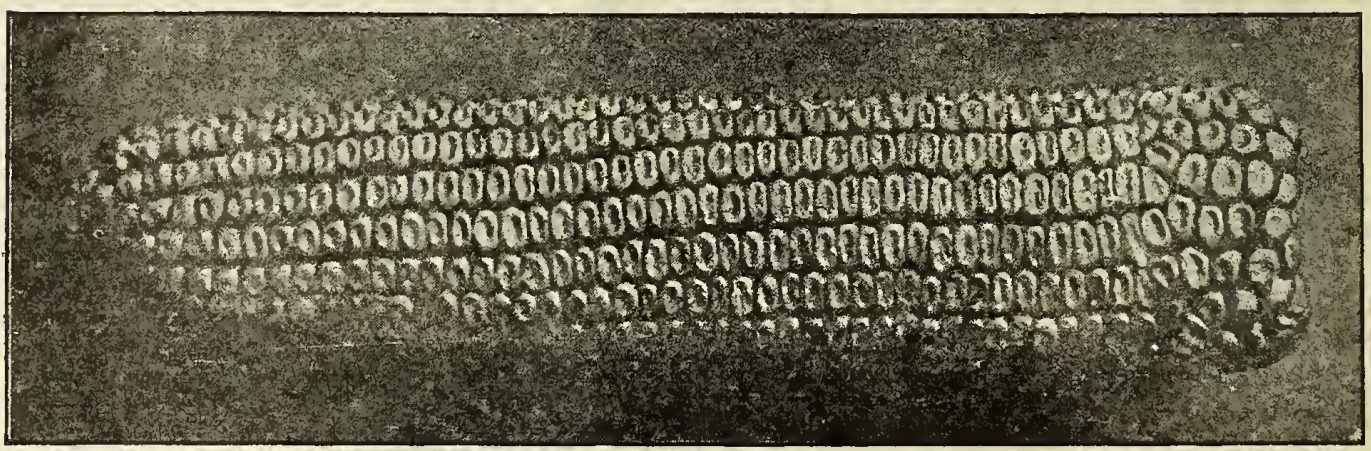

EARLY MURDOCK

\section{LATE VARIETIES}

Reld's Yellow Dent-Corn light golden in color; ears 9 to 11 inches long; 18

to 20 rows of kernels, each row contalning 50 to 60 kernels.......................

lowa Gold Mine-Now a well known standard corn and still one of the very best; ripens in about 100 days; grain deep rich yellow dent; very small

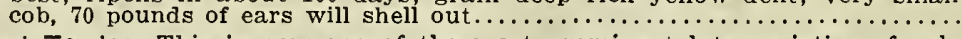

Legal Tender-This is now one of the most prominent late varieties of yellow dent corn in the country. It is the result of about 10 year's selection by a seed corn specialist in Iowa, and has taken first premiums at many state and county fairs. The corn is productive of uniform pure many state and county fairs. The corn is productive of uniform pure yellow color; ear very large and long; a deep grain on a small cob. while the stalk does not grow too large. The introducer says: "Our to 20 rows, and small shank. The kernels are deep. the cob is small at butt and ear holds its bigness toward the polst, until near taperlng or. It matures in about 115 days, but we do not recommend it for the northern portion of this state. Our stock of this ls extra select, grown from the originator's stock seed, but improved in earliness by being grown in

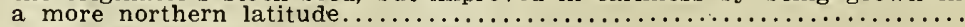

lowa Sllver MIne-One of the very best choicest white corns for the north-

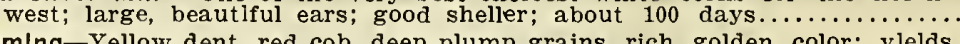

Leamlng-Yellow dent, red cob, deep plump grains, rich golden color; ylelds

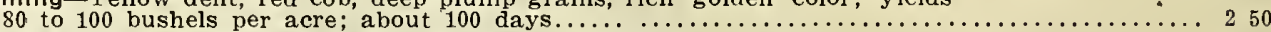

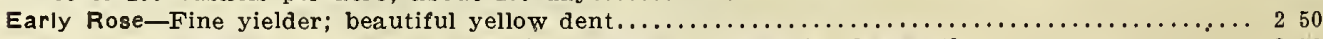

Champlon White Pearl-A very large white corn, well known in the south..................2 50 


\section{THE BEST VARIETY OF POP CORN}

Rose-A very productive variety. Ears short, kernels long and pointed. A Qt. Pk. 1/2 Bu. Bu. splendid popping sort; the most salable among the retail dealers.....\$ $\$ 0.10 \quad \$ 0.70 \quad \$ 1.25 \quad \$ 2.25$ White Peari-Smooth, small grain; ears 4 or 5 inches long, seven-eighths to

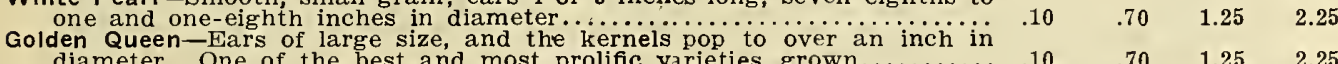

diameter. One of the best and most prolific varieties grown........... $.10 \quad 70 \quad 1.25 \quad 2.25$

\section{DULY'S HYBRID}

We wish we could thoroughly impress upon the farmers of Iowa, Nebraska, Southern South Dakota and Minnesota the great value and safety in placing our Duly's Hybrid. We will place it along side of any corn of any name by any seedman and show conclusively that there is no corn for this latitude equal to it in merits. Let us give you a little of its history: Some ten years ago we found this corn in the hands of a Mr. Duly, of Dakota City, Nebraska, a thorough, practical, hard-headed farmer, who made great claims for it. We purchased some of the corn for seed and have given it a thorough test in these years and have had reports from thousands of farmers as to its value. It has even proven a greater corn than we had anticipated. When we first found the corn it was rather too light a yellow and the ears too slender and long and kernels too short but cor the The are deeper. In all of our experience we have never had a corn with such potency. In all kinds of

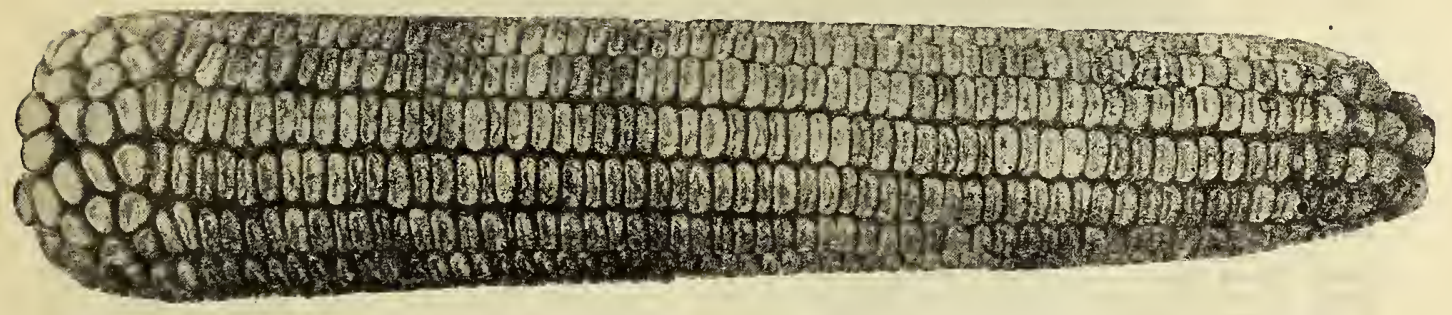

Corn 9 to 11 inches

DULY'S HYBRID

100 Day Corn

weather, soil, and under all conditions, it comes up smiling with strong, vigorous stalks, large, beautiful ears and plenty of them. At first it is apt to be condemned, but we have yet to find the first planter who, after having planted and grown it, codemn it, but all of one accord sing its praises. Duly's Hybrid will stand more rough treatment than any corn we ever saw-cold, wet, drought, light frosts, etc. It will give a good stand in cold, wet weather when other corns will not. It belongs to the 90-day class of corn and is as heavy a yielder as the best, running 70 to 80 bushels to the acre.

\section{Farmers, Dairymen, Stockraisers}

\section{TRY THE EVERGREEN SWEET FODDER CORN}

The necessity for green fodder is becoming more apparent each year to all dairymen and stock raisers, and the demand for it is increasing in pooportion as the ability of our overtaxed lands to supply sufficient pasturage grows less. The best thing for the purpose is our

\section{EVERGREEN SWEET FODDER CORN}

This variety is generally acknowledged by our best farmers, dairymen and stock growers as being better and far superior to what is known as either of the brands of ensilage, corn, Red Cob Ensilage, or Southern White Ensilage, from the fact that it grows to an immense size, making a large juicy stalk, that is so very sweet and nutritlous that cattle will eat every part of the stalk and luicy stalk, that is so very sweet and
leaves with a relish, clean to the butt.

Evergreen Sweet Fodder Corn also yields an enormous quantity of leaves, and the stalks are rich in saccharine matter-more so than any other variety we are acquainted with.

For prices, see page 11.

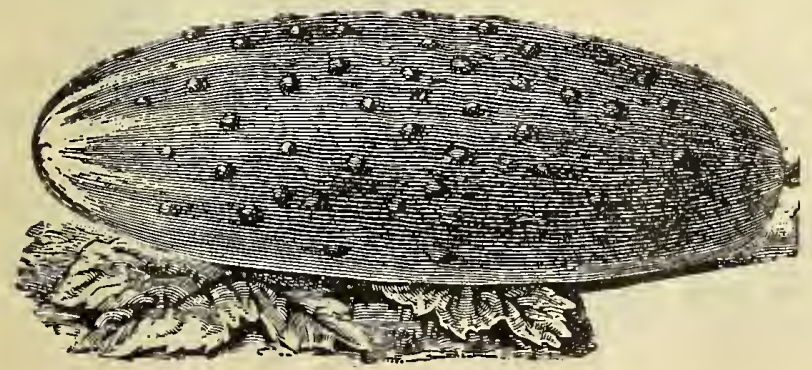

\section{Cucumber}

Arlington White Splne-A selection from the White Spine, being more pointed at each end, the young fruits are usually crisp and tender and are of very dark green color, so that the variety is considered by name to be the best for small pickles.

Pkt. Oz. 1/4 Lb. $1 \mathrm{Lb}$.

$\begin{array}{llll}\text { Price.......... \$0.05 } & \$ 0.10 & \$ 0.25 & \$ 0.80\end{array}$ 


\section{CUCUMBER-Continued}

New Cumberland-A variety of the haray White Spine type. The pickpkt. oz. 1/4 lb. $1 \mathrm{lb}$ les being thickly set with fine spines. During the whole period of growth, from the time they first set untll full grown, the form is exceptionally straight and symmetrical, making them as choice for a slicing variety as for pickles

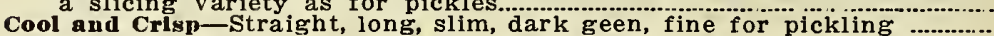
Fordhook Famous-Long, straight, vigorous grower; very productive.......... Dariy Cycloue-A short variety. The earliest by two weeks of any cucumber in cultivation; iolds its color well and is very prolific, growing its fruit in bunches of three and fours and sometimes producing 10 to 12 specimens to the plant

The Davis Perfeet Cucumber-An excellent cucumber for both outdoor use and forcing. It is a carefully selected strain of the extra long Whlte Spine type made by a veteran outdoor and greenhouse grower of cucumbers. Its valuable points are length, slimness and its dark green color. It is a very vigorous sort and resists blight longer than most iong sorts

Boston Pickling-A favorite eastern sort of fine quality

Chleago Pickilng-Very popular in Chicago market. Color deep green, medium size, prominent spines

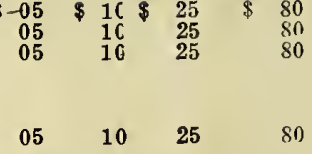

$\begin{array}{llll}05 & 10 & 25 & 8 n \\ 05 & 1 \mathrm{C} & 25 & \text { s0 }\end{array}$

$05 \quad 16 \quad 25 \quad 80$

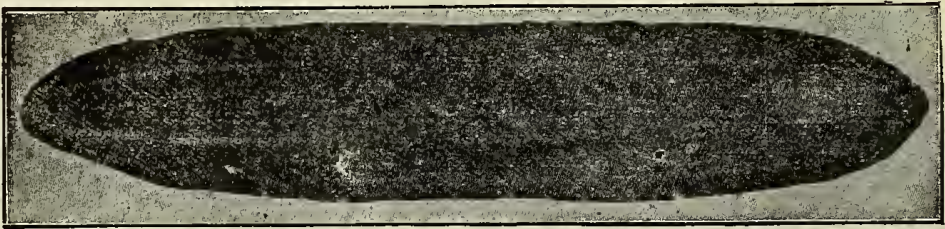

The Davis Perfect Cucumber

Eariy Iussian-Very early, short, is a valuable varicty for small pickles,

or which it is often much in demand

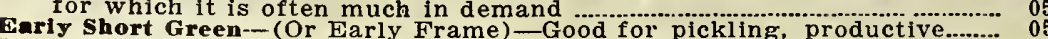

Gariy Green Cluster-Fruit small and in clusters; very prolific

Eariy White Spine-Farly, and good for pickling or table use

Gvergreen-Very early and prolific: retains its fine deep green color in all stages of growth

Giant Pera-Very long and one of the best for table use

Green Prolifie Pickling-One of the best for pickling, dark green, very

productive and of uniform small size for pickling, dark green, very

Japan Cilmbine

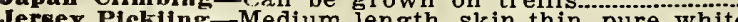

improved White Splne Well flavored and of medium size

con

Long Green-Long and crisp, a popular and reliable variety for pickles....

Long Green Turkey-Fruit very long and rather slim

Nichol's Medium Green-Most symmetrical and a very fine table sort........

Small Gherkin-Very small bur, used for pickles ….................................

long; quality fair

\section{ENDIVE}

CULTURE-Sow in June, July and August, cover lightly, when up thin out to eight inches apart and water well afterward if dry. When the leaves are six to eight inches long, blanch apart anering in the arter and done when guite dry, or they will rg together near the top with take up carefully, witi a ball done when quite dry, or they will rot. At the approach of winter take up carefully, wit. a ball dry and have plenty of air, or they will rot.

Green Curied Winter-Standard sort for fall and winter crop pkt. oz. $1 / 4$ lb. $11 \mathrm{~b}$. Broad Leaved-A sweet variety, fall and winter.

\section{EGG PLANT}

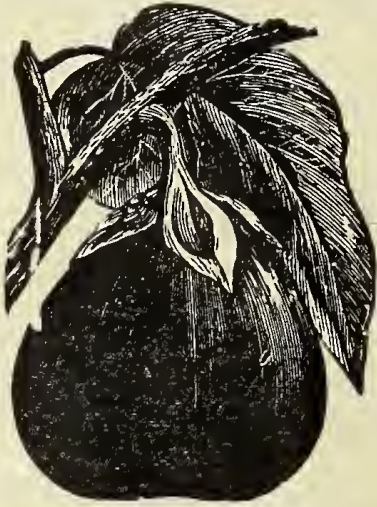

Improved New York Purple
CULTURE-Sow in hot beds, very early in spring, and transplant when two inches high into a second bed or into small pots. If that is not done, thin to four inches apart. Do not plant out until the weather becomes perfectly settled and warm. Cool nights or wet weather will check them.

Early Long Purpie-Of distinct shade and fine quality -..... pear-shaped pale purple, good

Improved New York Purple-The best large oval, deep purple, grown more extensively than any other sort

Black Benuty-Fruit broad and thick, rich deep black, spineless, very eariy dis

wlorida High Bush-Bush grows high and stiff, frujt about like $N$. Y Purple, fine shipper, one of the very best egg plants

$\begin{array}{rrrrrrr}\text { pkt. } & \text { oz. } & 1 / 4 & 1 \mathrm{~b} . & 1 & 1 \mathrm{~b} . \\ & 05 & \$ 20 & \$ & 50 & \$ 1 & 75 \\ 05 & 25 & & 75 & 2 & 25 \\ & & & & & & \\ 05 & 35 & 1 & 00 & 3 & 50 \\ 05 & 35 & 1 & 00 & 3 & 50 \\ & & & & & & \\ 05 & 15 & 1 & 00 & 3 & 50\end{array}$




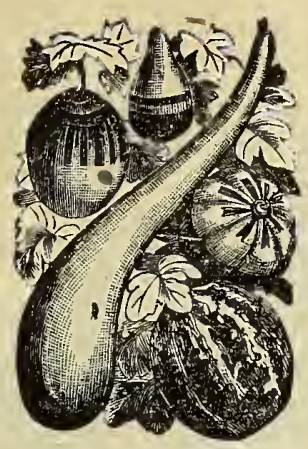

\section{Useful Gourds}

Nest-Hgg-Resemble in color, form and size, the eggs of pkt. 02. $1 / 4 \mathrm{lb}$ hens; do not crack, and are uninjured by cold or wet. They make the very best nest-eggs. Do not plant in very ricli soil, or the fruits will grow too large

Sugar Truugh-By sawing of the upper portion large dishes or buckets may be made, which are useful for many household purposes. The shell when dried is thick and hard, light but very durable.

Dipper-. When grown on the ground the stems will be curved; as a climbing vine the weight of the blossom end will cause the stem to grow straight..........

Disheloth or Luffa-A natural dishcloth, and 2 most
admirable one, is furnished by the peculiar lining of this fruit, which is sponge-like and durable...... $10 \quad 15 \quad 50$

\section{Kale or Borecole}

CULTURE-Cultivated and grown exactly like cabbage. Sow early in the spring in a hot bed and when from one to two inches high, transplant into a bed or border that has been highly manured and deeply dug. The plants should stand two feet apart, in rows three feet apart. The soil should be kept mellow and free from weeds. Cover with litter or leaves during the winter. Plants started grown this way should be fit to blanch the following spring. The seed may also be sown early in the open border, and transplanted in rows (as directed above) as soon as out of the seed leaf; but they will need to be a year older than the hot bed plants before being fit to blanch.

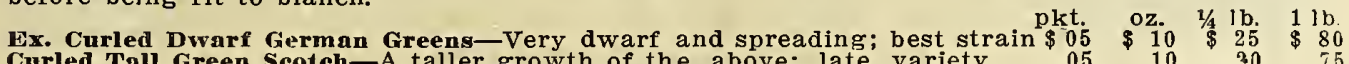

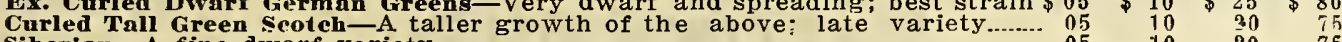
Siberian-A fine dwarf variety

\section{Kohlrabi}

CULTURE-This is an excellent vegetable and should be grown in every garden. Sow in the spring, in rows eighteen inches apart, afterwards thinning the plants to eight or ten inches. If the weather is suitable, the thinnings may be planted, but it is considered difficult to transplant. Keep the weeds down and when the thickened stem above ground is two or three inches through, they are fit to eat, and should be used at once, being tough when old. They are cooked the same as turnips, and when well grown and used at the proper stage, are tender and palatable.

Eearly white Vienua

Handsome and del-

icate, white ball.......\$ $05 \$ 20 \$ 60 \$ 200$

Early Purple Vienna

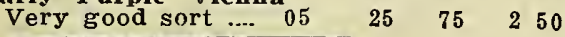

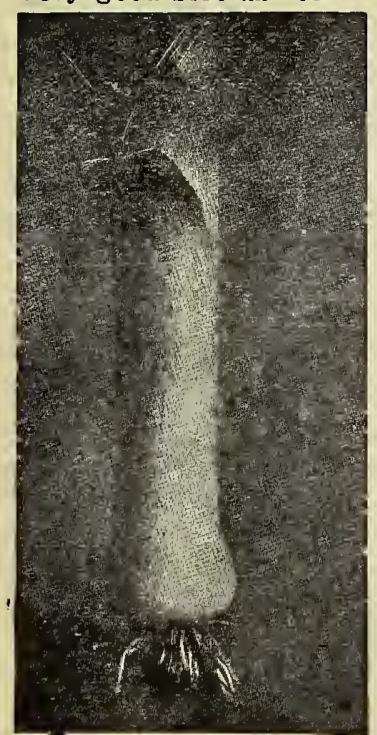

Warge Flag Leek

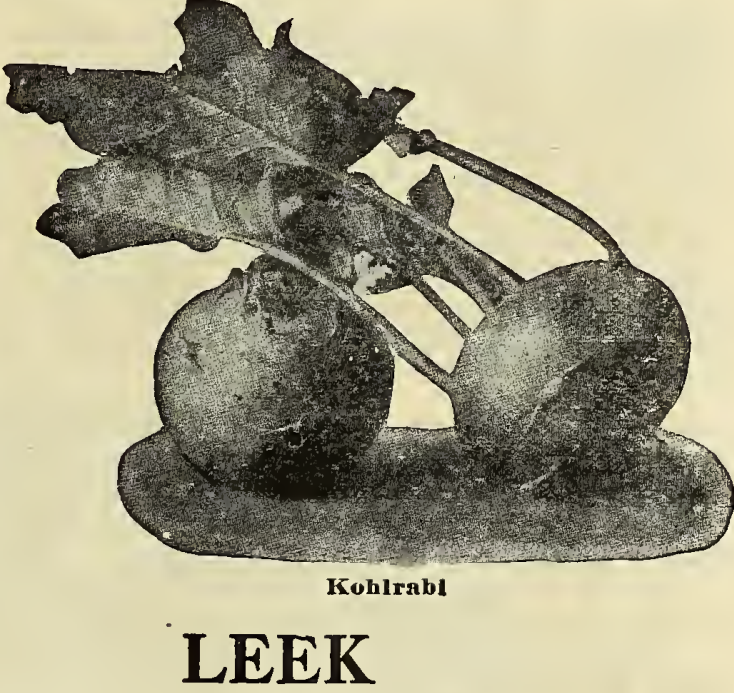

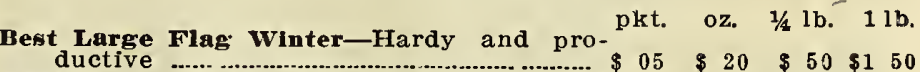

Musselburg-Large standard sort; remains long in good condition ...............................

Large Carentan-A superior variety with distinct and dark colored leaves; stout in habit and hardy

$\begin{array}{rrrrrr}05 & \$ 20 & \$ 50 & \$ 1 & 50 \\ 05 & 20 & 50 & 1 & 50 \\ & & & & & \\ 05 & 20 & 50 & 1 & 00\end{array}$

\section{LETTUCE}

Ready for Use in 40 to 60 Days.

California Cream Butter- Round, solid heads, medium green, good size, compact, rich, buttery taste ... olid cabbage-lettuce for summer

Denver Market-An early variety for forcing on open sround; large solid head: leaves beautif lly marked and blistered very crisp ....................................................

Early Curled simpson-A leading early sort; very tender

$\begin{array}{rrrrr}05 & \$ 10 & \$ 25 & \$ 80 \\ 05 & 10 & 25 & 80 \\ 05 & 10 & 25 & 80 \\ 05 & 10 & 25 & 89\end{array}$




\section{LETTUCE-Continued}

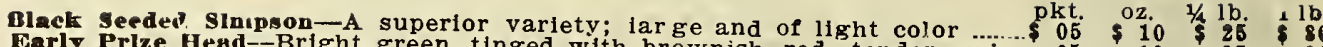
Early Prize Head--Bright green, tinged with brownish red, tender, crisp $05 \quad 10 \quad 25$ for the Southern gardener who ships North. Also vopular variety first early in the North. Plants are large, vigorous very valuable as ilght green, very tender. Our strain is un surpassed leaves bright, ers in the South will plant only Vaughan's

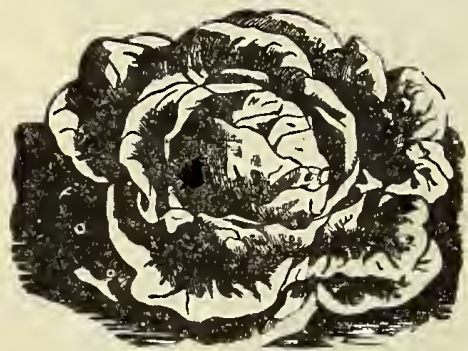

BIg Boston-Head Lettuce

Carly Curled Silesia-An early, erect growing, clustering variety, which may be sown very thick and cut while the plants are very young, ly tender, sweet and well flavorly tender, sweet and well flavor-

Grand Raplds Forcing-Large, tender heads, one of the best for early

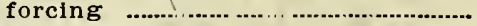

Iceberg-Fine compact heads which resist summer heat admirably, is very popular; leaves curled and light green; crisp, tender .............

Improved Hanson - Very large and solid, sweet, crisp and tender......

Parls White Cos-Fine if sown very early, requires tying up to blanch Tennlsball White Seed-A well-known forcing variety

Tenniwball Black Seed-Forms close hard heads; good for forcing ................ White Summer Cabbage-Close heads of good size; fine for summer.......

\section{MELON-MUSK}

BUIRELL'S GWM-New Salmon-Fleshed Musk Melon-Grown in a comparatively cool location or at a considerable elevation, the Burrell Gem comes close to perfection, having fruits of good size, handsome appearance, and of fine flavor, but when grown in light, warm soils. the melons come with softer flesh and are liable to split or crack open at the blosgom end. The melons are six to seven inches long by four and a half to five inches in diameter rather sharply sloping at the ends They eter, rather sharplo sloping at the are quite weth ribbed a cine grayn, contrasting finely with the deep orangegrean, contrasting finely with the deep orangeflesh is thick and firm, ripening close to the skin, leaving only a thin rind.

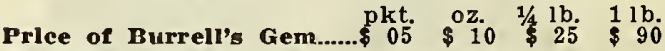

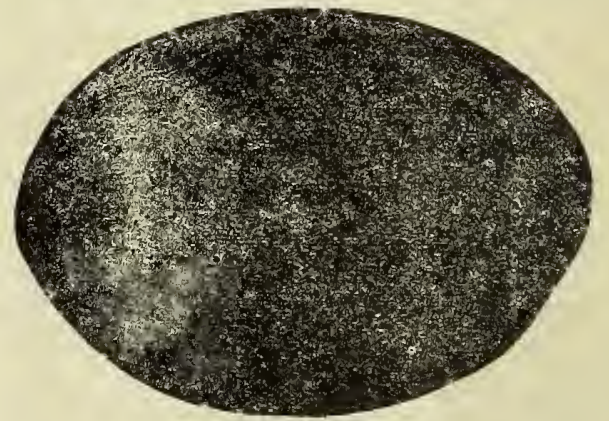

irrell's Gem......\$05 \$ $\$ 10$ \$25 \$90 Bnrrell's GeI Baitlmore Market-Oblong; orange flesh, fine quality

Emerald Gem-Small, extra early; smooth ribbed, dark green skin and orange flesh; quality first rate, very sweet

RoCKY FoRD-This is the most popular of the basket melons; oval, light ribbed, densely covered with coarge green netting, flesh thick, green Top-Melons are round in form, well-ribbed; light green skin; flesh is thick, bright salmon in color, of luscious melting character; firm for shipping purposes

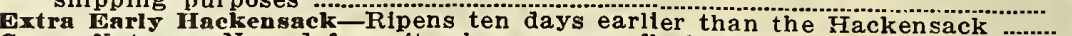

Green Nutmeg-Named from its shape, green flesh, good for main crop .......

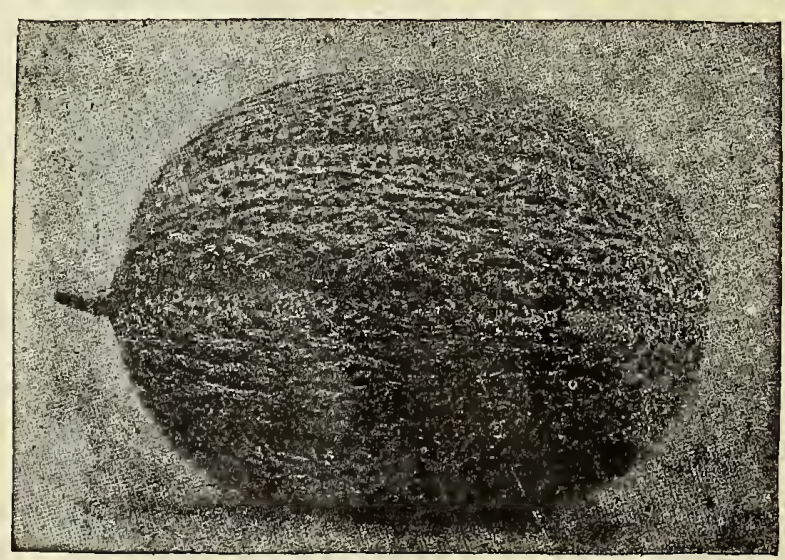

Extra Farly Hackensack

Green Montreal I arge, $r$ o i $n$ d, net ted, fles

$\begin{array}{lllll}\text { thick and light } 05 & 10 & 20 & 75\end{array}$

Golden Netted Gem -Very early: is small and of fine

$\begin{array}{rrrr}5 & \$ 10 & \$ 20 & \$ 75 \\ 5 & 10 & 20 & 75 \\ 5 & 10 & 20 & 75 \\ 5 & 10 & 20 & 75 \\ & & & \\ 5 & 10 & 20 & 75 \\ & & & \\ 5 & 10 & 20 & 75 \\ 5 & 10 & 20 & 75 \\ & 10 & 20 & 75\end{array}$

Jenny Lind-Small, but very early $\begin{array}{lllll}\text { and of good qual- } & & & & \\ \text { ity; green flesh.. } & 05 & 10 & 20 & 75\end{array}$

Lony Yellow Can. telonp - Yellow flesh, well adapt ed for the North; late 05

Late HuckensackLarge, round, and of gond quality; a popular vari- 05

Defender-One o1 the best yellow fleshed; fine 05 


\section{MELON--MUSK-Continued}

Mango Melon or "Vine Orange"-(Also called "Vegetable Peach") 一 Size shape and color of an orange; thick, meaty flesh; besides its use fo

preserving or pickling, it can be fried like Egg Flant when partly ripe $\$ 05 \$ 10 \quad 20 \quad 75$

Netted Beauty-Extra early dersely netted; flesh pale green ... pape.

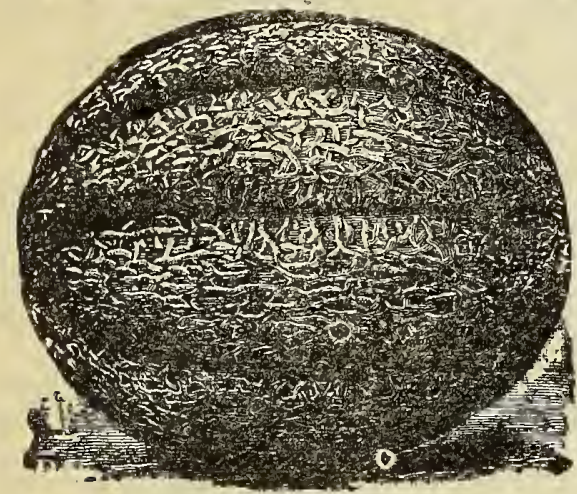

Emeruld Germ osage - Coeoanut shaped, yellow flesh, light green, netted skin Phneapple $\rightarrow$ Medium sized, oval shaped, tapering to stem; flesh green, very thick; delfcate and exceedingly high flavored; intermediate

Paul Rose or Tetof $₫ y-$ T'nsurpassed in quality, unexcelled for shipping, flesh firm, rich orange color, covered with dense net. ting not ribbed

J'rineess--Salmon fleshed, very distinct, nearly round, dark green, netted, sweet and luscious.....

Shumway's Giant-Very large, cream yellow, very distinct salmon colored flesh, sweet and salmon colored flesh, sweet and

The Banquet - Beautifuly netted medium sized, flesh rich salmon The Surprise-Farly, oblong, with rich orange flesh of good quality .........................................

White Japan--Warly, with light green flesh and whit
Texas Cannon Ball-Round, finely netted, green flesh

\section{Mustard}

CUUTUI:-Sow thickly during early spring in shallow drills, and press the earth well down. For fall salad, sow in September or in frames or boxes during the winter.

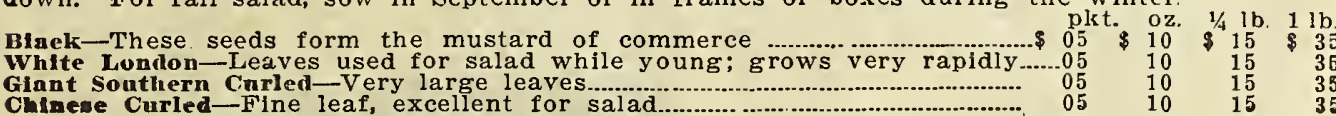

\section{MELON-WATER}

\section{Ready for Use In 60 to 90 Days.}

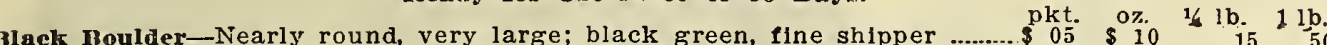

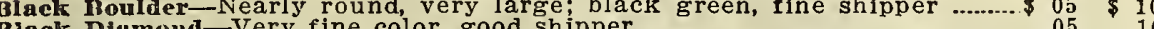

on

.

Citron-Round and handsome, for preserving; late ....................

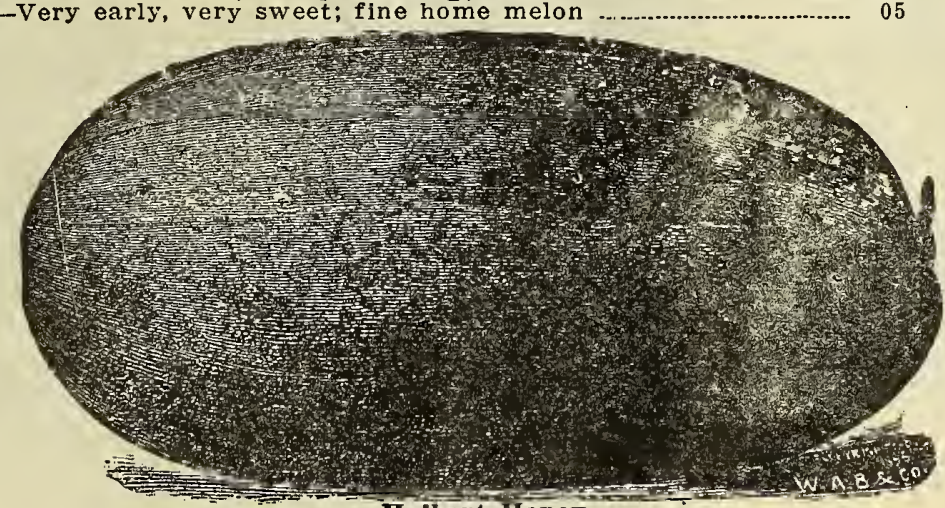

Halbert Honey

Cuban Queen-Solid and heavy, skin marked regularly; excellent quality

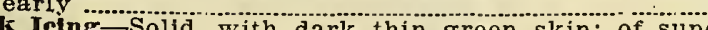

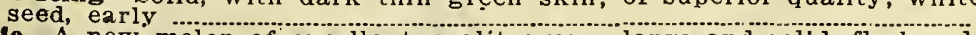
Dixle A new melon of excellent quality; very large and solid, flesh red;

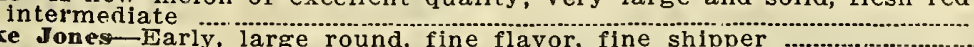

Duke Jones-Early, large round, fine flavor, fine shipper ..................... medite

Fordhook Eariy-An extra early, of extra fine flavor, and large size, color a viniform green; average welght from 30 to 40 pounds

Gray Monarch or Long Light Ieing-Largest melon grown; crimson flesh: ine; late

Ialbert Honey-Brought out by Burpee a couple of years ago as the sweetest of all melons, and I am inclined to belleve that he is right about it. They are much like Kleckley, but longer in shape; dark green, very sweet and very tender. Break easily in handling. I,arge

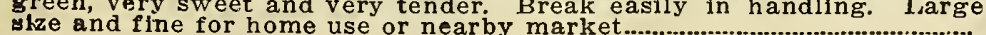




\section{MELON-WATER-Continued}

Iceberg (Blue Gen)-Large, thick oval form, rich dark green, fine shipHumgarian Ioney-A very early sort from Hungary; fine for northern latitudes; perfectly round, flesh brilliant red, seeds very small .......... Kencucky Wonder-Oblong, dark green skin, scarlet flesh ............................ Kleckley's Sveet or Monte Christo-Oblong, rich dark grcen, flesh Kleekley's Sweet or Monte Ch
bright scarlet; very sweet

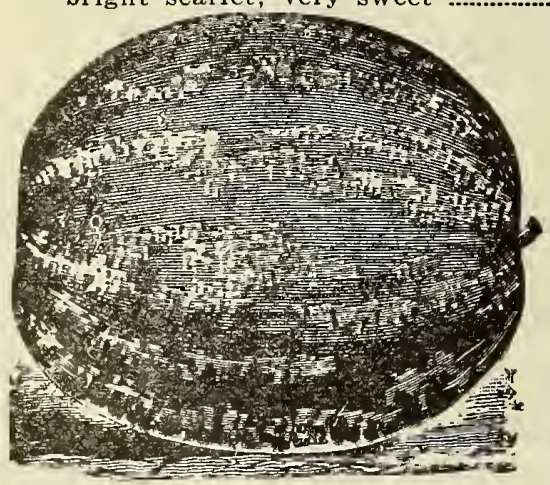

Jones' Jumbo-Very large, fine green color, meat deep red, fine shipper .......................... flesh, of fine quality and good shipper, intermediate.....

Light Ising-Fiound, pink flesh, of fine quality ............................ Mountain Sweet - Large oval variety, green rind, flesh scarlet, sweet and delicious; fine for home garden -.................... Rattlesnake, but is very much superior, fine shipper .............

Mammoth Ironelad-Long, very

late, red flesh, good shipper.

Peerless or Ice Cream-Very early; red flesh, good home melon ,...................................... fine quality; red flesh, fine for the North ........

Cuban Queen

Sweet Mountain-An old and reliable sort; ilesh red, late........ 0

Seminolc-Very large; quality first rate; intermediate ............................ green skinned, delicious sugar flavor, seed small, one of the best for Sweetheart-One of the best early shipping melons; fruit large, oval, mottled, light green, flesh bright red, firm, melting and sweet....... A labaua Sweets- gng, dark green, fine flavor, fine shipper........

pkt. oz. $1 / 4 \mathrm{lb}, 1 \mathrm{lb}$.

$05 \$ 10 \quad 15 \quad 50$

$\begin{array}{llll}05 & 10 & 15 & 50\end{array}$

\section{MARTYNIA}

\section{FOR PICKLES}

CULTURE-Sow in May in the open ground, three feet apart in each direction, where the plants are to remain; or the seed may be sown in a hot bed and seedling afterward transplanted. Both varieties are productive and fine for pickles. Pick when small and tender, and preserve the same as cucumbers.

Proboscidas?

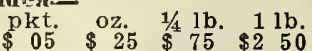

\section{Nasturtiums}

CULTURE-Sow as soon as all danger of frost is past, in drills about an inch deep. The tall kinds require fences or poles on which to seeds are used for flavoring pickles or as a substitute for capers.

Tall Mixed-

\begin{tabular}{lllll} 
pkt. & oz. & $1 / 4$ & $1 \mathrm{~b}$. & $1 \mathrm{lb}$. \\
\hline 05 & $\$$ & 15 & $\$ 30$ & $\$ 1.00$
\end{tabular}

Dwarf Mixed- $1 / \mathrm{b}$

\begin{tabular}{llllll} 
pkt. & oz. & $\frac{1 / 4}{4}$ & $1 \mathrm{~b}$. & $1 \mathrm{lb}$. \\
\hline 05 & $\$$ & 15 & $\$$ & 30 & $\$ 1.00$
\end{tabular}

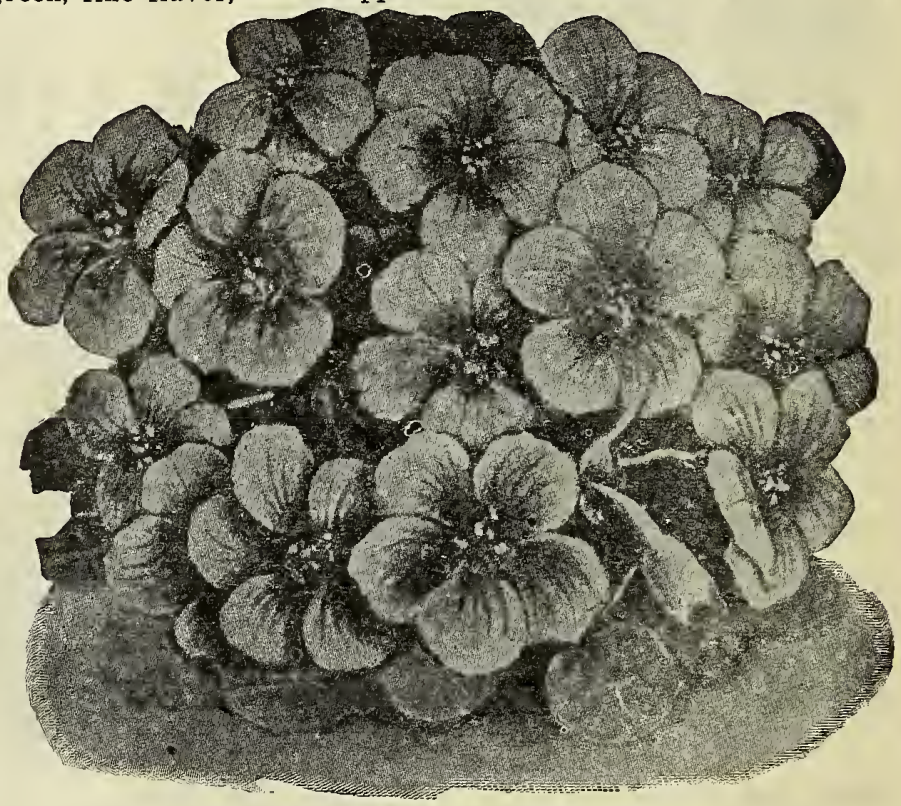

Nasturtium Dwarf

Okra or Gumbo

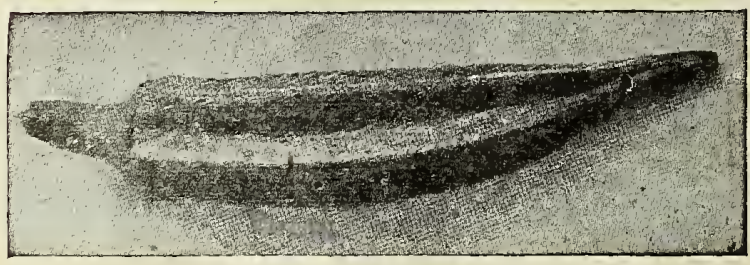

Okra or Gumbo
CULTURE-Sow late in the spring, after the ground has become warm, in drills three feet apart, where the plants are to remain. Thin out from nine to twelve inches. They should be well. manured. They may also be raised in pots or a hot bed and transplanted. pots or a hot bed and transplanted. Dwarf .................. \$ 05 \$ 10 \$ 15 \$ 60 $\begin{array}{lllll}\text { Long Green ......... } & 05 & 10 & 25 & 60 \\ \text { Enrly Dwarf ........ } & 05 & 10 & 25 & 60\end{array}$ White Velvet-Long pods; fine flavor;

very tender ... 


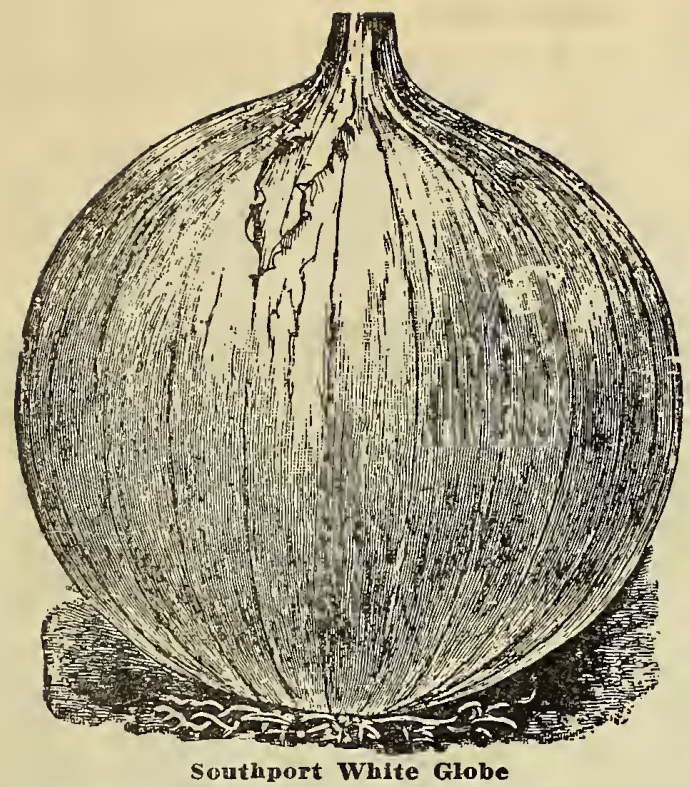

Large White Portugal-Standard sort, flat

Large White Globe--Large Southport strain

Glant White Tripoli-Very large white

Early Red Flat Color of Wethersfield, early

Yellow Danvers (Flat) - A standard sort, rather oval, early, good keeper

Yellow GIobe Drnvers-Of more globular shape; keeps well good keeper

Large Yellow Globe-Southport strain, large, firm, mild, good keeper......

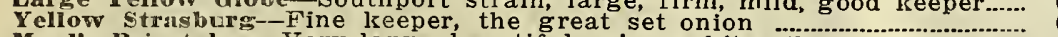

Maul's prizetaker--Very large, beautiful onion, white flesh, skin straw color; sweet, mild, tender; keeps medium, white flesh, slin straw

Early Red Globe--Fine onion, mil handsome globe onion with a brownisli-yellow skin and crisp fine-grained white 2 to $21 / 2$ inches in diameter and ripen a little earlier than the Red Globe

Mammotia Silver King- - Yery large, white skin and flesh, mild flavor, flat shape: frequently weigh three lbs.

New Crystal white (Teneriffe Seed)-Large pure white, finest slicing onion for the home garden. is very scarce

White Bermila (Tenneriffe Seed)-The Bermudas are the earliest onions in the market, and are zrown extensively in the South. Outer skin straw color,

Red Bermuda (Tenneriffe Seed) - Similar to the white, but with red skin

are t ed Giobe-...

Southport strain, one

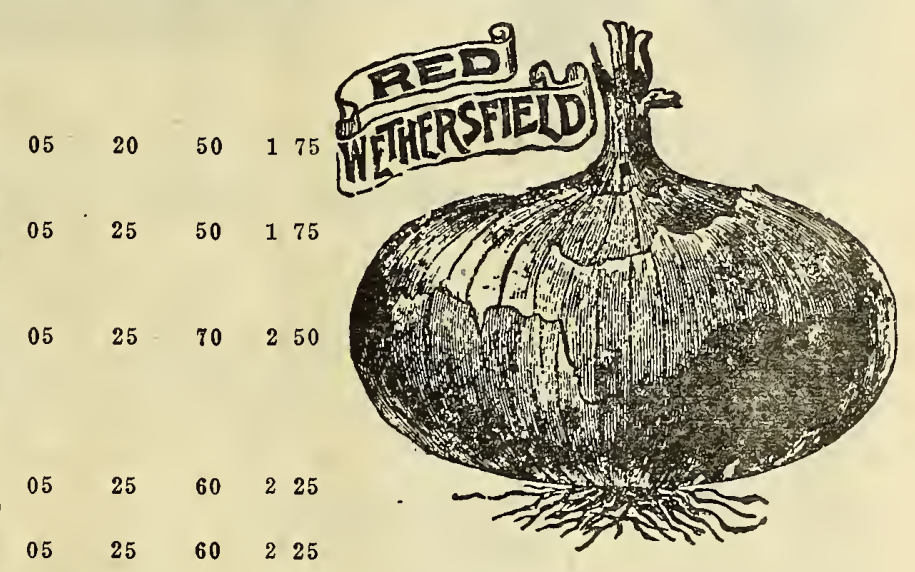

$05 \$ 20 \quad 50 \quad 175$

a good keeper: stand

ard sort ................

Cross between Red

W e th ers field and

beautiful oninn, fine

keeper, fine for tlie

good keeper .............

white sort; earliest

of all, fine for pick-

New Queen-Very early

small white sort, the

best for picleling .... 05

\section{Onion Sets, Top, Etc. \\ PRICES ON APILICATION}

Yellow Onion Sets, Bottom Red Onion Sets, Bottom Vhite Oniou Sets, Bottom

Yellow Potnto Onlone White Potato Ouion Top or Button onion:

\section{PEAS}

Ready for the Table in 50 to 70 Dars.

CULTURE-A week nay be gained in earliness by sowing a quantity in moist sand, placed In a bux in the cellar, planting outside when well sprouted. Light dry soil, not over rich, suits the pea. Sow as early as the ground can be worked, and again every ten days, for succession, up to the first of June, after which there is danger from mildew. Sow in single or double rows. trom four to six feet apart, according to the different heights, about an inch apart in rows (excepc such sorts as we note to sow thin) and four inches deep. Hoe often and keep the ground an and fine. The tall sorts can be made to bear more freely by pinching-in. The duarl varieties may be grown in beds like Bush Beans, with rows about the same distance yuar ine voles which are sometinies found in veas are caused by the Pea Weevil, (Bruchus pisi, inls inste is a native of this country, but as usual with such pests, has spread rapidly pisi. is now funna nearly all over the world. Lithe peetles lay their eggs on the young pods 


\section{PEAS-Continueu}

and the larvae, as soon as hatched, make their way through the pods into the nearest peas They do not, as is sometimes supposed, destroy the germ, for peas will grow if they are Infegted, but the plant is likely to be more feeble, and for this reason will not produce as larse

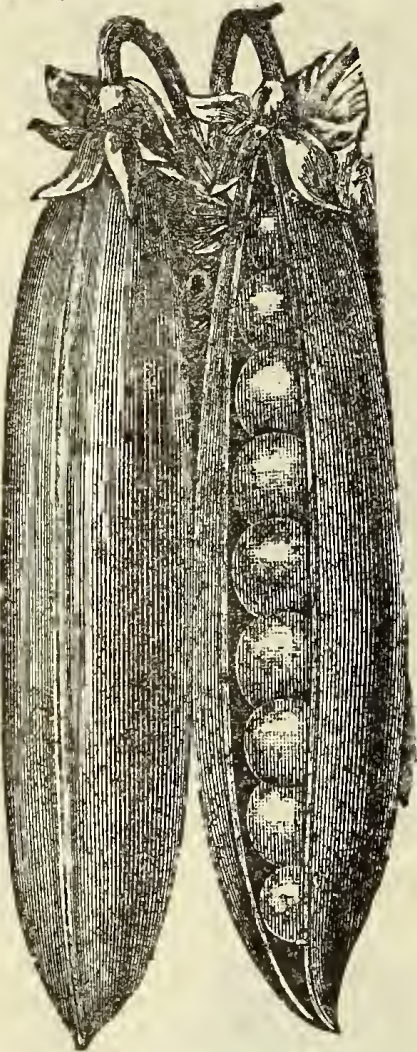

Peas marked thus (*) are wrinkled

GRaDUS-A new English variety of the wrinkled peas; it is very hardy, so much so that, unlike most of its type, it can be planted extremely early; the vine grows about $2 \frac{1 / 2}{2}$ feet $h i g h$, is vigorous and very productive; the pods are large and wellfilled with good sized peas, seven to nine usually in a pod. The Gradus is the earliest wrinkled pea in cultivation and one of the most delicious in quality.

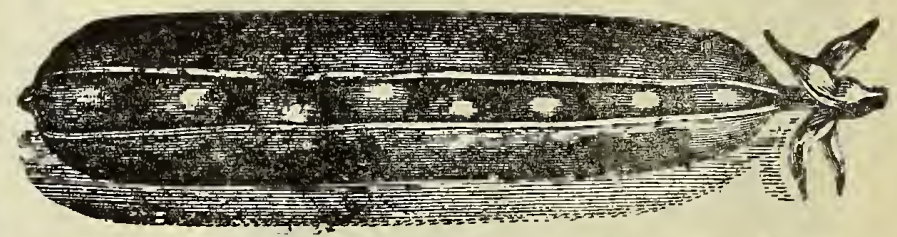

Nott's Excelslor-The Best Early Wrinklcd Pea Sold.

-NOT'S EXCELSIOR-The Finest Dwarf Wrinkied Extra Early Varlety - It is the best of recent introductions; vines are larger and more vigorous than the American Wonder, while the pods are fully one-third larger, containing six to elght fine large peas, packed so closely together in the pods that the peas are always more square than round. The pods are always well filled with peas, which in sweetness and quality have no equal, being superior to any other wrinkled sort.

-THOS. LAX'TON-The only rival to the famous Gradusas a long-podded extreme-early wrinkled pea-and in some respects even better. The growth is identical, but the pods are a deeper, richer green and square at the end. In the judgment of experts, Thos. Laxton is even sweeter and finer in flavor, whlle as the large peas are of a deeper green they present a more attractive appearance on the table.

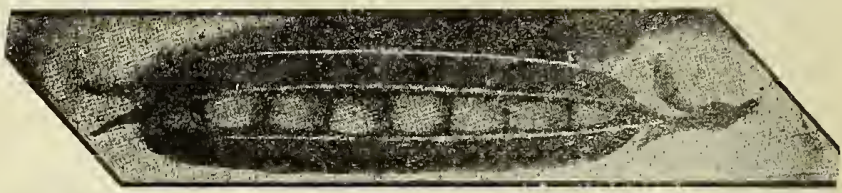

Alask:

SURPIISE or ICCLIPSE-One of the best of the new wrinkled peas. The vine grows 20 to 24 inches lifh, requiring no sticks. One of the most profitable sorts for the gardener to grow. Same price as Gems.

\section{EXTRA EARLY PEAS}

Nott's Excelsior $\mathrm{He}_{2}$ 'ht in $\mathrm{ft}$

'Nott's

Thos. Laxton

Rural New Yorker-Very early; prolific and uniform in ripening 21/2

Firwt nud Best-Farly, reseinbing Early New Yorker .............. $21 \%$

Alaska-One of the very earliest blue peas; quite productive.... $21 ;$

- Apha- An extra early wrinkled pea; sow thick ..................

- American Wonder-Nearly as early as Alaska, a good yielder

- Little Gem-McLean's very desirable early pea, great producer, good quality

- Pre

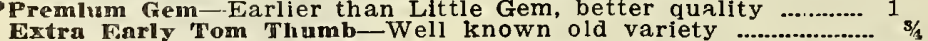

\section{EARLY AND MEDIUM PEAs}

- MeIain Advancer-A fine standard sort of excellent quality.... $21 / 2$ - Horsefurd Market Garden-On the style of Advancer; very prolific

- Everbearin-Long pods and large peas; sow thin

-Abundance Bliss-Medium early; vine fine ................................. $11 / 2$

- Teiephone-Very valuable, vigorous grower, pods large, sweet 4

Pride of the Market-Pods large ...................................................

Dwarf Telephone or Daisy-A medium late pea that needs no brushing. It is of dwarf, stock habit, healthy, vigorous growth, and productive, bearing large, handsome pods and peas of highest quality

\section{LATE PEA}

-Champlan of Eugland-A well-known standardpea. , w thick

- Heroive-Large, full pods, enormously product

irine sugar-One of the best edible pod urts -...........- 4

Mammoth sur-One of the best edible pod .urts …….................

Mammoth Surar-Gray seed, Immense edible pods ................... 5

- Divari wrinkled Sugar-Large, well filled pods, very productive 1 1/2

- Stratnurnt-The finest second early, vigorous and productive: eight to ten large peas in pod, unsurpassed in quality … 2 to 5

Marrowiut, Black-Eyed-The best Marrowfat.

Merroviat, White-An old standard sort, quality inferior, great

Mielder ........................................................................................... 4 to 5

pkt. Ib. $15 \mathrm{lbs} .60$ lbs. $\begin{array}{rrrrrr}10 & \$ 15 & \$ 2 & 00 & \$ 7 & 50 \\ 10 & 15 & 2 & 00 & 7 & 50\end{array}$

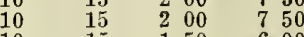

$10 \quad 15 \quad 150 \quad 600$

$\begin{array}{llllll}10 & 15 & 1 & 50 & 6 & 00 \\ 10 & 15 & 1 & 50 & 6 & 00\end{array}$

$\begin{array}{lllll}10 & 15 & 200 & 750\end{array}$

$\begin{array}{llllll}10 & 15 & 1 & 75 & 6 & 50\end{array}$

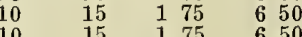

$\begin{array}{lllll}10 & 15 & 1 & 75 & 650\end{array}$

$\begin{array}{llllll}10 & 15 & 1 & 75 & 6 & 50\end{array}$

$\begin{array}{lllll}10 & 15 & 175 & 650\end{array}$

$\begin{array}{llllll}10 & 15 & 1 & 75 & 6 & 50 \\ 10 & 15 & 1 & 75 & 6 & 50\end{array}$

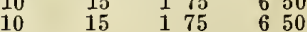

10

15

200

800

10 


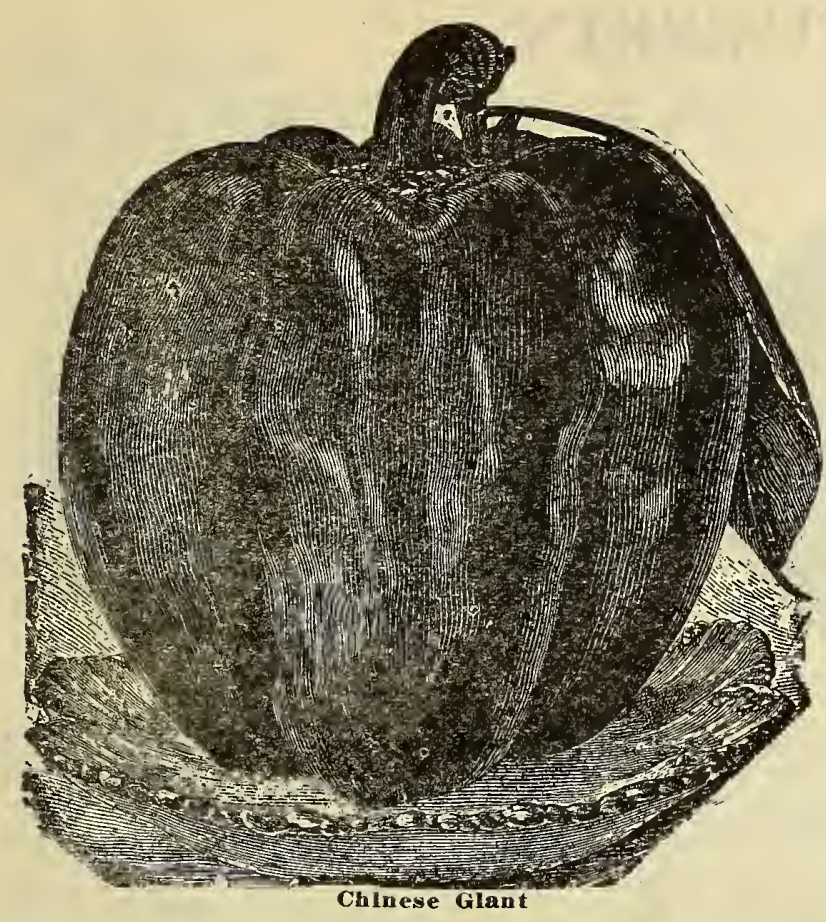

\section{PEPPER}

CULTURE-Sow in hot beds in March, and when the soil has become warm, set in rows two feet apart and elghteen inches in the rows, hoe frequently and keep down all weeds. The plants may also be forwarded in pots.

Sweet Golden Queen-Very handsome and distinct, and of mild flavor.... $\$ 05$

Rnby King-Beautiful bright red, large frult, mild, one of the best; fine for pickles

Large Squash-Productive, much used for plckling

Long Red Cayenne - Bright red, very productive

Large Bell or Bull Nose-Large and mild, excellent for pickling .

Procopib Giant-Very large size and brightly colored, fine flavor

Red Cherry-Cherry shaped; for pickles, for which they are largely used

Red Cluster-A new type of Chill, with upright bright red fruits ...........

Sweet Mountain-Large, regular and of mild flavor, one of the best for pickling

Celestial-A Chinese Pepper; at first fruit is yellow, and when fully matured becomes a deep scarlet .

Chinese Glant-(See Cut) - A very large, fine, mild red pepper. Not only is it immensely productive for so large a pepper, but its enormous size and magnificent appearance make it sell most readily. The plants are vigorous in growth, well branched and thickly set with enormous fruits. Fruits blocky, 4 to 5 inches broad, color brilliant scarlet

pkt. oz. $1 / 4$ lb. $1 \mathrm{lb}$. $\begin{array}{lllll}05 & 20 & 60 & 1 & 75\end{array}$ $\begin{array}{lllll}05 & 20 & 60 & 1 & 75\end{array}$

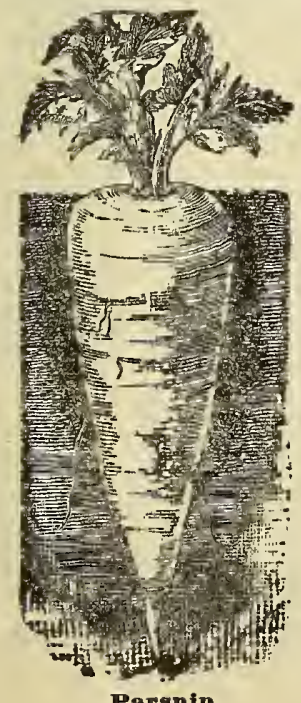

Parsnip

\section{Parsnip}

Hollow Crown-A market gardener's st in $\ldots . . . . \$ 05 \$ 10 \quad \$ 20 \quad \$ 50$ Long Smooth White-Long white, smooth, no side roots; tender and excellently flavore. ........ $05 \quad 10 \quad 20 \quad 50$ $\begin{array}{llllll}\text { Student-A half long varlety of deliclous flavor.... } & 05 & 10 & 20 & 50\end{array}$

\section{Parsley}

CUUTRE-Soak the seeds a few hours in luke warm water, and sow early in the spring until the middle of July, in drills one foot apart. Thin out the plants to four inches. To preserve in winter transplant to a light cellar or cold frame.

Double Curled-superior

pkt. oz. $\quad 1 / 4$ lb. $1 \mathrm{~b}$.

Champlon Moss Curled-Very pretty and one of the very best

$\begin{array}{llll}05 & 10 & 20 & 50\end{array}$

Fern-Leaved-Fine curled .........................................

Hamburg or Rooted-Edible roots, much like parsnips 


\section{PUMPKIN}

CULTURE-May be planted middle of spring, among corn or in the field or garden, in hills 8 or 10 feet apart each way, 4 seeds in a hill. In other respects are cultivated in the same manner as melons and cucumbers. Avoid planting near other vines.

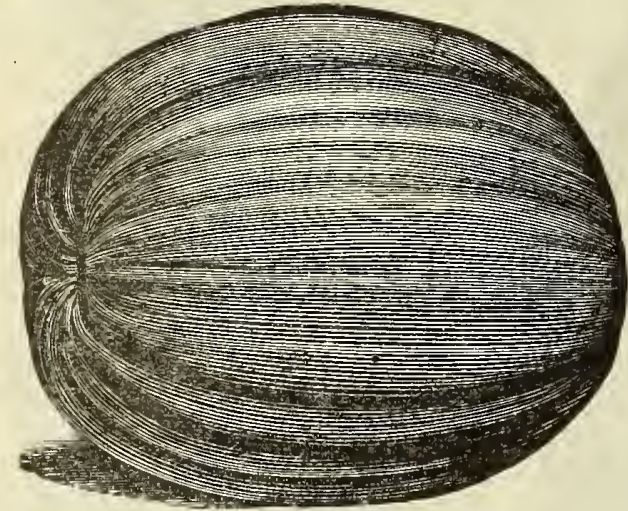

Connecticut Field

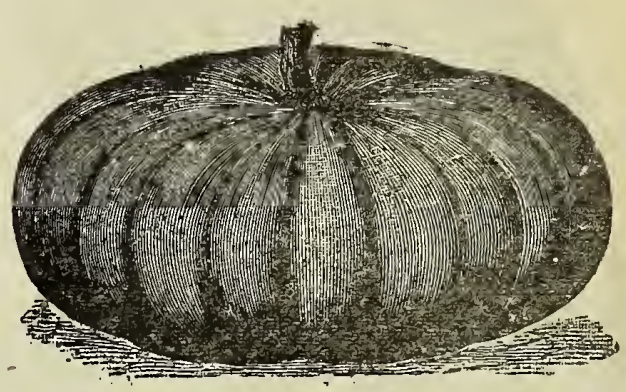

Large Cheese

Large Cheese-Flat; one of the best varieties for family use; good keeper $\$ 05$ oz. $1 / 41 \mathrm{~b} .1 \mathrm{lb}$. Sweet or Sugar-Fine grained, sweet and prolific; small yellow, best for pies

Quaker Ple-Fine for pies, very prolific and a good keeper

Striped Cushaw-Medium size, crookneck, very productive

Striped Cushaw-Medium size, crook

White Cushaw-Fine white color

Red Etampes-Medium size, flat, fine for cooking

Mammoth Potiron-Grows to an enormous size, 150 to 275 pounds; fine for exhibition

Mammoth Tours-A very large French variety

Tennessee Sveet Potato-Bell shaped; thick, white flesh, fine for pies .... 05

Commecticut Fleld-Grown for stock; very productive

$\begin{array}{llll}05 & 10 & 15 & 40 \\ 05 & 10 & 20 & 60 \\ 05 & 10 & 20 & 60 \\ 05 & 10 & 20 & 60 \\ 05 & 10 & 20 & 60 \\ 05 & 10 & 20 & 60 \\ 05 & 10 & 20 & 60 \\ 05 & 10 & 20 & 60 \\ 05 & 10 & 20 & 60 \\ 05 & 10 & 10 & 30\end{array}$

\section{RAPE}

\section{DWARF ESSEX}

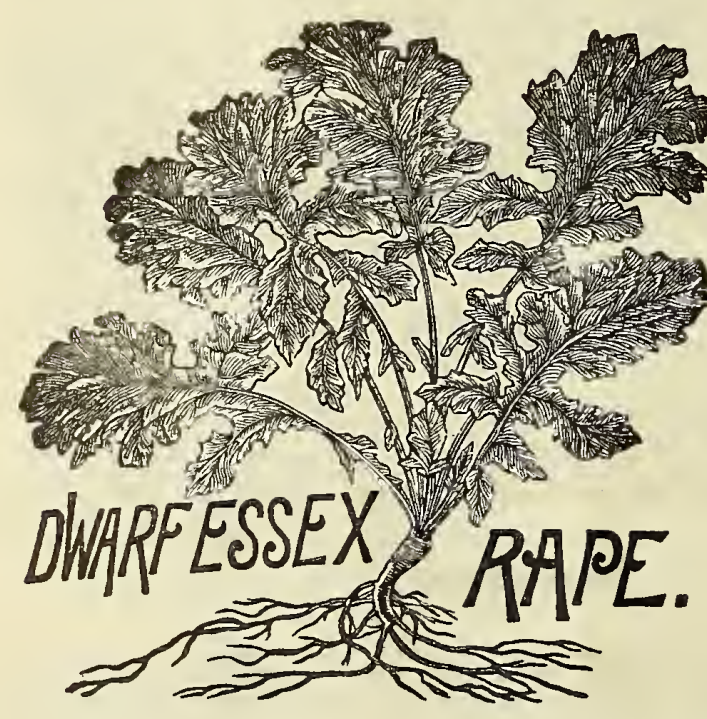

A most profitable forage plant. We can think of no simple change which would do more to increase the profitableness of American farming than a more general use of Dwarf Essex Rape. It is an inexpensive crop, costing but little for seed or for cultivation, is very hardy, is very hardy, can be made to take will yield of some crop that has failed, and will yield an enormous crop of forage, or it can be sown after harvest as a cover crop, and, will rapidly restore the fertility of exhaustcd soils. It is imiportant that the true biennial Dwarf Essex Rape should be used, and not the annual sort, which is not only much less valuable as a crop, but which when once introduced, becomes a pernicious weed very difficult to eradicate.

MANY FARMERS are sowing Dwarf Essex Rape with their wheat or uther spring sowing crops, putting it right in the drills with the grains sown. The Rape plants do with the not develop sufficiently to interfere with the growing grain, but after harvest comes on rapidly. It does well to sow after the corn has been laid by and when the corn has been husked it furnishes the very

n connection with twelve pounds $\$ 1.25$ lbs. and over, 8 cents per pound. For larger lots, write for special prices.

\section{Rhubarb.}

Mammoth-Very large, but good quality Linnaeus-The earliest

victoria-Very fine in quality, but small

Roots-Per dozen, 60 cents; per $100, \$ 4.00$. 


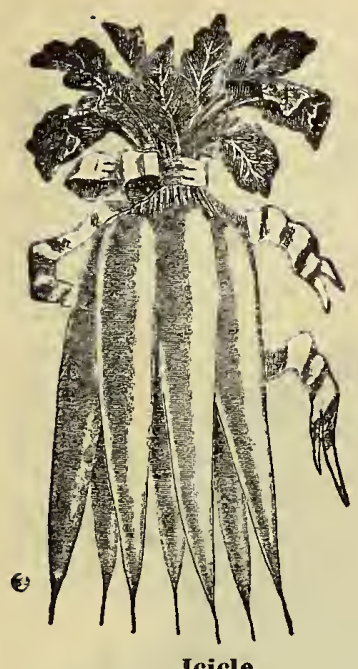

Icicle

\section{RADISH}

leady for Use from

18 to 25 Days.

CRIMION GIANT-This we consider the greatest new radish in the last ten years. It is of German origin. It is an early radish, looking much like the old Early Scarlet Globe, but more perfect in shape and color. It comes as early as any radish, but the amazing thing about it is that it keeps on growing and remains tender, solid and sweet, till it gets as large as a teacup or larger. Just imagine cup or larger. Just imagine Radish you ever saw, deep red outside and pure white inside, fine flavor, and as large as a teacup and you will have a good idea of it.

Crlmson Giant

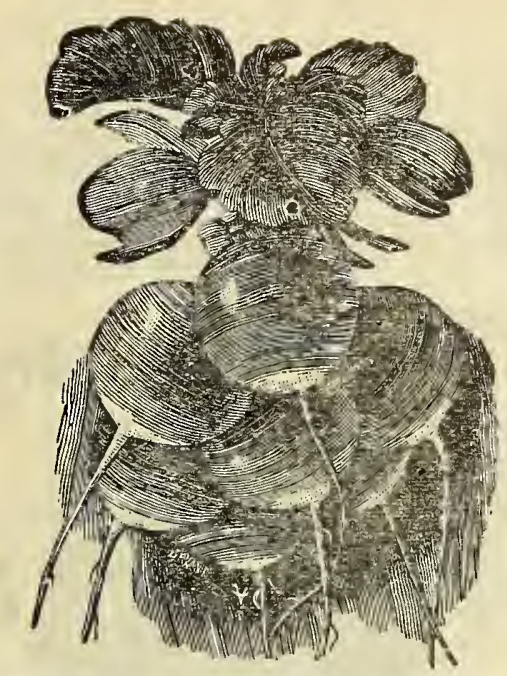

Early Scarlet Turnip White Tlpped plit. nz. $1 / 4$ 1b. $11 \mathrm{~b}$ $\$ 05 \$ 10 \quad \$ 20 \$ 60$

Turnip Early Scarlet-Very early, crisp; good forcing

Turuip Early Deep Scarlet-Very early; used for forcing

Turuip Early Searlet White Tipped-Very early, for frames or outaors This is one of the best for market gardeners

$05 \quad 10 \quad 20 \quad 60$

French Breakfast-Earliest, most handsome, tender and crisp. Deep glossy crimson with white tips

$05 \quad 10 \quad 20 \quad 60$

- Rosy Gem-One of the very best for malket gardeners; very early, tender, beautiful scarlet, shadins off into a white tip

* Turuio Larly Ne Plus Ulara-Extz̃ a arly scarlet forcing, short leaved

Turnip Early Deep Blood Red-Ixtra early forcing sort

-Turuip Early White or Box-Suitable for forcing. fresh, pure white and sweet

Turnip Yellow Summer-Dull yellow, fine flesh...

Turnip Golden Summer-Smooth and bright skin

Turnip Gray Summer-Good solid summer sort...

* Olive-Shaped French Breakfast-Pink and white, early; standard sort

ollve-Shaped White-Mild and fine for summer...

*Long Scarlet Short Tol-Very long and crisp, for frames and open ground

*Long Brightest Scarlet-White tipped, very bright and beautiful

* Long Scarlet Chartier White Tipped-Shades from crimson to white; tender

*Long Wood Early Frame-Long, red, crisp, and good for forcing ....................................................

Long White Vienna or Lady Finger-Crisp and tender in summer; one of the best

The Icleie-A new introduction of the Long White; beautiful ivory white color; fine slender form, quality excellent; very early; fine for market

White Starsburg Summer-Very large; the German's favorite; quality fine

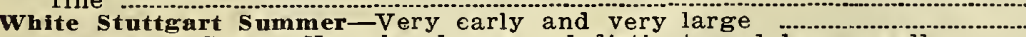

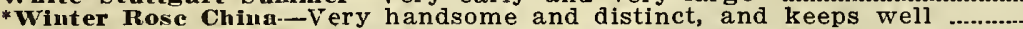

winter Round Hlack Spanish-Fine for winter.

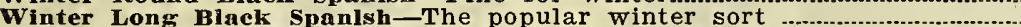

Winter Califoruia White Mammoth-A very large white winter variety....

05

05

05

05

05

05

0

05

05

05

05

05

05

05

$05 \quad 10$

0510

$05 \quad 10$

0510

\section{Salsify, or Vegetable Oyster}

Long White French

Mammoth Sandwich Island-Large and superior

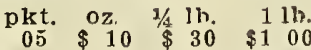

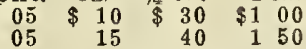

\section{SPINACH}

Viroflay Thick Leaved-Has very large and thick leaves

Carled-Leaved Savoy or Bloomsdale-Large, tender leaves, fine .................... Long-Standing Round Thick Leaved-Dark green, very long standing before running to seed

New Zealand-Entirely different from the tree Spinach in type and in that it thrives during hot weather and in any soil, rich or poor. The tender shoots are of good quality and may be cut throughout tlie tender shoots are of good quality and may be cut throughout tlie
summer. Plant three or four seeds in hills two feet apart each way. Summer. Plant three or four seeds in hills two feet apart each way. By using only the leaves it will sprout out again

$\begin{array}{rrr}\$ 10 & 15 & \$ 40 \\ 05 & 15 & 40 \\ 05 & 15 & 40 \\ 05 & 15 & 40\end{array}$




\section{Squash}

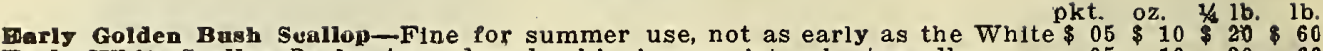
Golden Summex Crookneck-One of the very best summer squashes .......... Eer Plant Bush Squash-A whlte fleshed bush variety, oval in shape; sultable for frylng tike Egg Plant

Early Orance Marrow-An improved Boston Marrow; quite distlnct, very

early and of most dellcious flavor: sultable for fall or winter..........................

$\begin{array}{llll}05 & 10 & 20 & 30 \\ 05 & 10 & 20 & 60 \\ & 10 & 20 & 60\end{array}$
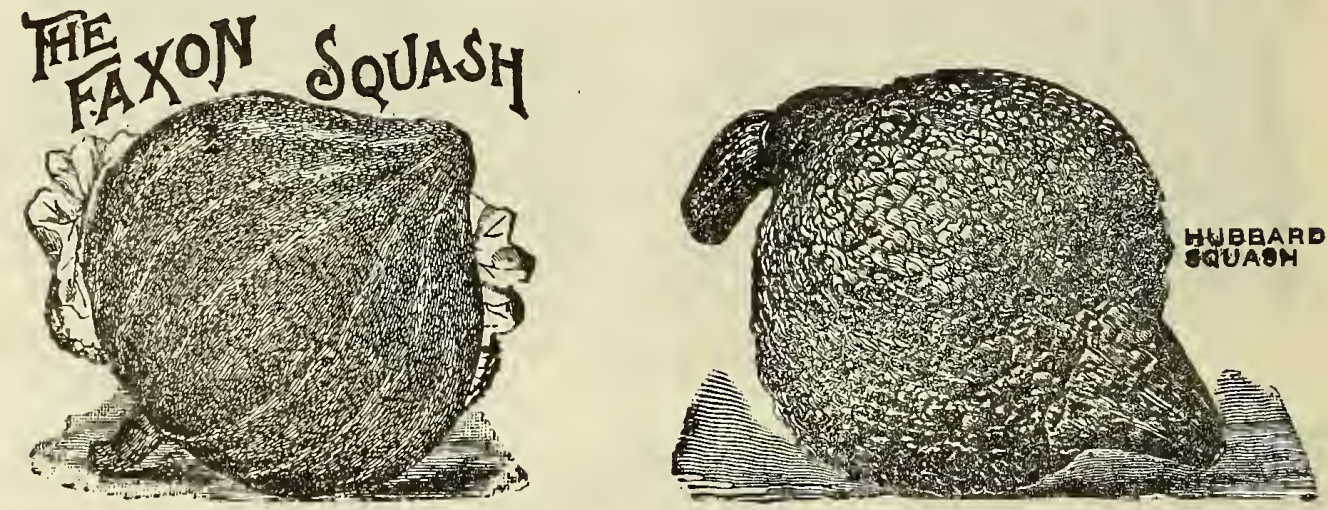

Boston Marrow-Oval, bright orange, flesh yel low and fine

Hubbard-Well known and liked for late use; of superior quality

Warty Hubbard-More warty, harder shell, better keeper, true stock

Fed or Golden Hubbard-Fine reddlsh or golden color large size fine quali....

The Faxton-Medium size, wery early, productlve; orange flesh of flne qual-

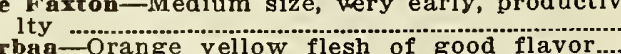

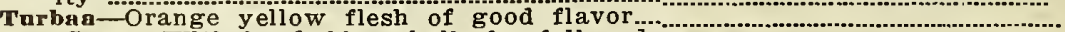

Bay State-Wlth hard, blue shell; for fall and wlinter

Pike', Peak or Slbley-Thick, bright orange flesh, fine winter sort Essex Hybrld-A good fall and winter sort

Marblehead-Resembllng the Hubbard, but has gray skln

Perfect Gem-Round, white, flne quallty, productlve, good for fak or wlnter Fordhook-One of the best wlnter squashes; flne quallty, bright yellow ....... Fin Pine Apple--Pecullar shape, white skln and flesh, llne late sort

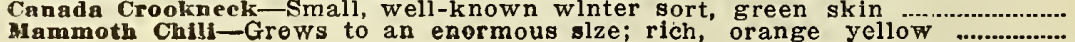

$\begin{array}{llll}05 & 10 & 20 & 60 \\ 05 & 10 & 20 & 80 \\ 05 & 10 & 20 & 80 \\ 05 & 10 & 20 & 80 \\ 05 & 10 & 20 & 75 \\ 05 & 10 & 20 & 60 \\ 05 & 10 & 20 & 60 \\ 05 & 10 & 20 & 75 \\ 05 & 10 & 20 & 75 \\ 05 & 10 & 20 & 75 \\ 05 & 10 & 20 & 75 \\ 05 & 10 & 20 & 75 \\ 05 & 10 & 20 & 75 \\ 05 & 10 & 20 & 75 \\ 05 & 10 & 20 & \mathbf{7 5}\end{array}$

\section{Tomato}

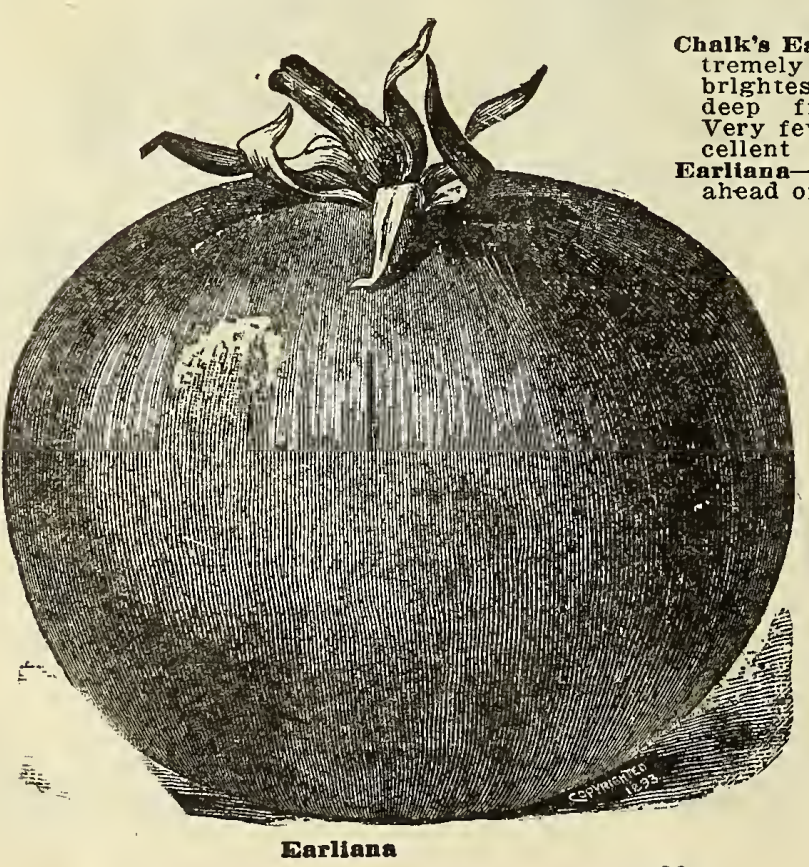

pkt. oz. $1 / 4 \mathrm{lb}, 1 \mathrm{lb}$

Jewell-An exvariety of eep fruited and solid.

$05 \$ 30 \$ 8 \theta \$ 200$ cellent flavor ahead of all others. Plants of strong growth and very productive. Fruits large, đeep red, and of superior quality. Smooth and free from cracks ................

Matchless - Fxtra largs - smotra and handsome brlght red, very solid

Ponderosa - T $\mathrm{he}$ largest variety in cultivation...

Atlantle Prizo il: smooth bright red and solld

solld ....................

$\begin{array}{lllll}05 & 20 & 60 & 2 & 00\end{array}$

Qulte distlnct in Qulte distlnct in follage and habit of growth, being compact and upright; frults sembles Acme in appearance .... 


\section{TOMATO-Continued}

Ignotum-Very prolific, earliest of the large, deep red, smooth varieties.... Pertecion (Livingstou) -Early, regular and productive, red, heavy cropper.. Favorite (Livingston)-Large, smooth, productive and good shipper

Beauty (Llvingston) - Large, smooth, pinkish-red. thick flesh, regular form Stome (Livingston)-Very large, perfectly smooth, fine bright scarlet; best

Aeme-Medium, red, smooth and good; one of the hest earlies

Avace-Bright red, medium sized, smooth, solid, very early

ayl Rod-A first class main crop variety; skin and flesh intense red......

Trophy, harge-Very solid, standard late sort, grown extensively for cannin

Conqueror-Very early, fruit of medium size

Yellow Plum-Round and regular, bright yellow; used for pickles..................

Peach-Resembles a peach, for preserves, pickles and exhibition: quality excellent

w Peach-Very handsome in form, and of a beautiful clear yellow color, is useful to contrast with other sorts

Red Cherry-Fruit about an inch in diameter, in bunches; used for pickles

lellow Cherry-Similar to preceding, save in color

Red Penr-shroed-Fruit of peculiar shape, handsome and solid

Uproht Station Tree-The earliest of all to ripen a small part of its fruit: it rows in a compact manner; and is well adapted to pots Ground Chers: (Husk Tomato)-Small and ornamental fruit used for proserves

Golden Queen-Large size, handsome, very smooth, good quality

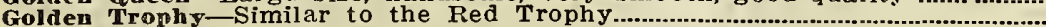

Tree Tomato

\section{TURNIP}

Carly Milan White-Very early, white top

Carly

Purple Top Munlel-One of the earliest

White Eroval, handsome and sweet

White ceg - Oval, handsome and swit e.....................

Eariy outcli $\rightarrow$ Rather flat, good.........

Red or Purple Top Strap Leaf-The popular flat fall sort; swet, ilrm and mild

\begin{tabular}{|c|c|c|c|}
\hline $\begin{array}{l}05 \\
05 \\
05 \\
05\end{array}$ & $\begin{array}{r}27 \\
20 \\
20 \\
20 \\
20\end{array}$ & $\begin{array}{r}1 / 416 . \\
\$ 60 \\
50 \\
50 \\
50\end{array}$ & $\begin{array}{r}1 \\
\$ 2 \\
1 \\
1 \\
1\end{array}$ \\
\hline $\begin{array}{l}05 \\
05 \\
05 \\
05 \\
05 \\
05 \\
05\end{array}$ & $\begin{array}{l}20 \\
20 \\
20 \\
20 \\
20 \\
20 \\
20\end{array}$ & $\begin{array}{l}50 \\
50 \\
60 \\
60 \\
50 \\
61 \\
60\end{array}$ & $\begin{array}{l}1 \\
1 \\
2 \\
2 \\
1 \\
2\end{array}$ \\
\hline 05 & 20 & 60 & 2 \\
\hline $\begin{array}{l}05 \\
05 \\
05 \\
05\end{array}$ & $\begin{array}{l}25 \\
25 \\
25 \\
25\end{array}$ & $\begin{array}{l}75 \\
75 \\
75 \\
75\end{array}$ & $\begin{array}{r}2 \\
2 \\
2 \\
2\end{array}$ \\
\hline 05 & 25 & 80 & 3 \\
\hline $\begin{array}{l}05 \\
05 \\
05\end{array}$ & 25 & $\begin{array}{l}60 \\
60 \\
60 \\
80\end{array}$ & $\begin{array}{l}2 \\
2 \\
2 \\
2\end{array}$ \\
\hline
\end{tabular}

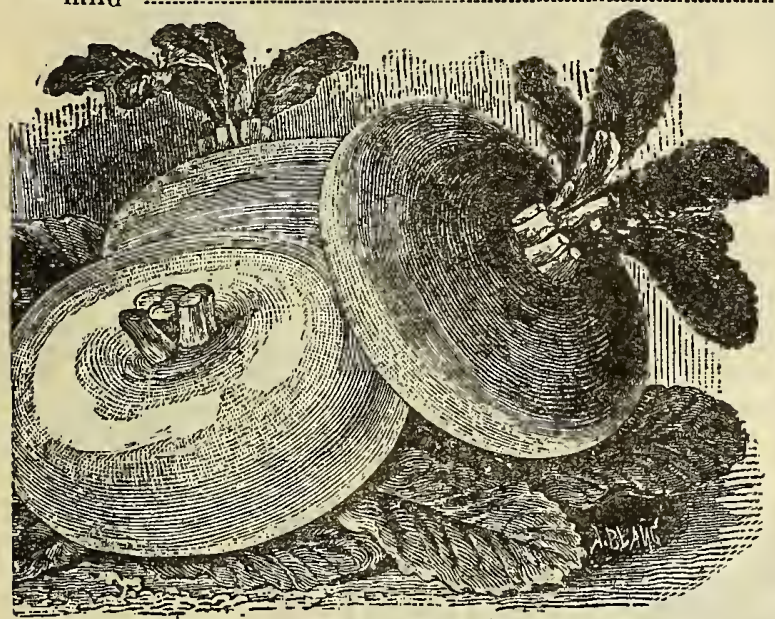

pkt. oz. $1 / 4$ lb. 1 lb.

I'omeranian White Gioba-Large, good for both table and stock Purple Top White Globe-A standard sort in the New York market; noth-

White Norfolk-Globular, late, solid, very large, fine for stock

White Stray Leaf Flat-A good early white flat sort

or stock; one of the best

Yellow Globe-Good and sweet; keeps fairly well

Yellow stoue trine hard wint, keeps

Goldeu Ball or orange Jelly-Very handsome; keep fairly well ...........

Snovball or Six Veels-A very rapid growing, small variety that will mature in forty days from sowing of seed. Flesh sweet and tender

Sweet Germnn-White, hard, firm, sweet; must be sown early; partakes of the nature of Ruta Baga

Yellow Aberdecin-Hardy, productive and a good keeper

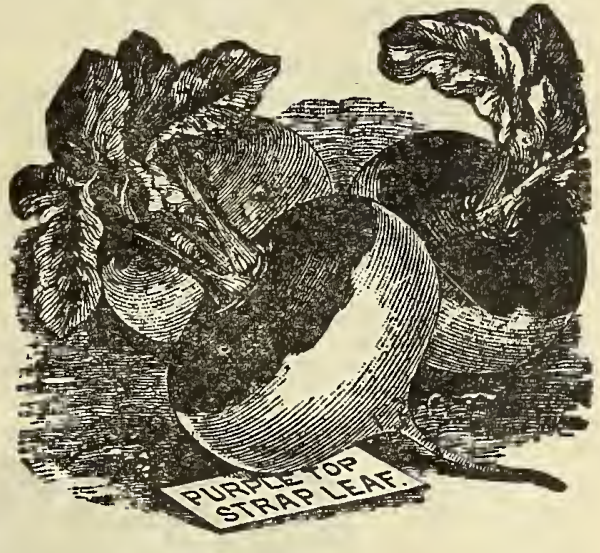

\section{Rutabaga, or Swedish Turnip}

Monareh-Distinct in form; a grand, good variets; very large yielder; grown mostly above the ground; flesh rich yellow ............................. and well flavored; deep purple; has but little neck ......................... Carter's Imperlal Hardy-A purple topped variety, growing to a largo size, single to root; good flavor

White sweed or Rusian-Excellent variety for either table or stock white flesh, fine flavor, good keeper

$\begin{array}{llll}05 & 10 & 20 & 46 \\ 05 & 10 & 20 & 45 \\ 05 & 10 & 20 & 45 \\ 05 & 10 & 20 & 45 \\ 05 & 10 & 25 & 45 \\ 05 & 10 & 20 & 40 \\ 05 & 10 & 20 & 40 \\ 05 & 10 & 20 & 40 \\ 05 & 10 & 20 & 40 \\ 05 & 10 & 20 & 40 \\ 05 & 10 & 20 & 40\end{array}$

pkt. oz. 1/4 lb. 1 lb.

$\begin{array}{rrrr}05 & 10 & \$ 20 & \$ 5 \\ 05 & 15 & 20 & 45 \\ 05 & 15 & 20 & 45 \\ 05 & 10 & 20 & 45\end{array}$




\section{Aromatic, Medicinal and Pot Herbs}

\section{GENERA, OULTURE DIRECTIONS}

Most of the varieties thrive best on rich sandy soil, which should be carefully prepared and well cultivated, as the young plants are for the most part delicate and easily choked out by weeds. Sow as early as the ground can be made ready, in drills sixteen to eighteen inches apart, taking pains that the soll is fine and pressed firmly over the seed, or they may be planted as a sccond crop, the seeds sown in beds in April and the plants set out in June. Most of them should be cut when in bloom, wilted in the sun and thoroughly dried in the shade.

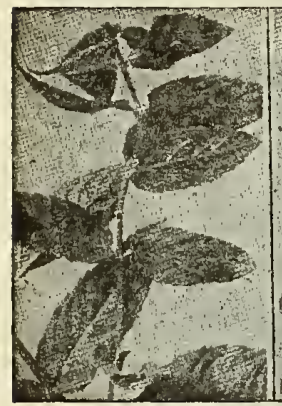

Peppermint

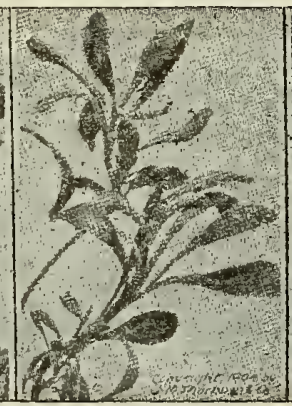

Lavender

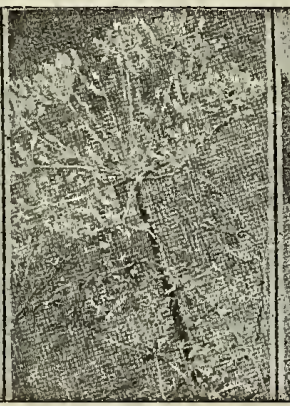

Fennel

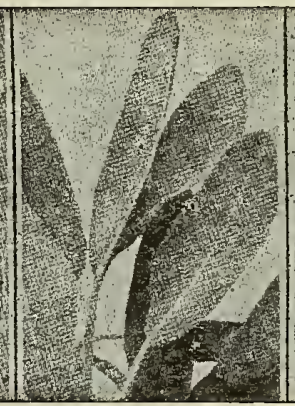

Sage

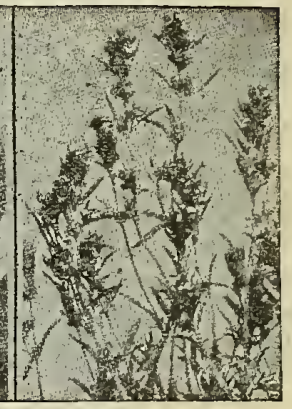

Summer Savory

Anime- A well known annual herb whose seeds, whicli have an agreeable aromatic odor and taste, are used for dyspepsia and colic and as a corrective of griping and unpleasant medicines. Sow early and thin to three inches apart in the row. Oz., $10 \mathrm{c} ; 1 / 41 \mathrm{~b}$., $30 \mathrm{c} ; 1 \mathrm{~b}$., $\$ 1.00$.

Balm-A perennial herb, easily propareted by division of the root or from $1 / 4 \mathrm{lb}$., $30 \mathrm{c} ; 1 \mathrm{~b}$., $\$ 1.00$. have a fragrant odor, similar to lemons, and are used for making balm tea for use in fevers and a pleasant beverage called balm wine. Plant early and thin to ten inches apart. Oz. $25 \mathrm{c} ; 1 / 4$ lb., $75 \mathrm{c}$; 1b., $\$ 2.50$.

Baw11, Sweet-A hardy annual from the East Indies. The seeds and stems have the flavor, of cloves and are used for flavoring soups and sauces. Oz., 15c; 1/4 1b., $40 \mathrm{c} ; 1 \mathrm{~b}$., $\$ 1.50$.

Caraway-Cultivated for its seed, which is used in confectionery, cakes, etc. The leaves are sometimes used in soups. If sown early in August, the plants will give a fair crop of seed the next season, but when sown in the spring will not seed until the next year. Plant in drills two or three feet apart and thin to six inches apart in the row. $0 \mathrm{z}$., $10 \mathrm{c}$; $1 / 4 \mathrm{~b}$., $25 \mathrm{c} ; 1 \mathrm{~b} .75 \mathrm{c}$.

Caraway for Flavoring-Oz., 10c; 2 ozs., $15 \mathrm{c} ; 1 / 4 \mathrm{~b}$., $20 \mathrm{c}$; $1 \mathrm{~b} ., 50 \mathrm{c}$. The plants should be pulled up by the roots when in full flower and dried in the shade. The seed may be sown eith

Coriandex-A hardy annual, cultivated for its seed, which has an agreeable taste, and is used in confectionery and to disguise the taste of medicine. Sow early in the spring and gather on a dry day, bruising the stems and leaves as little as possible. Oz., 10c; 1/4 1b., 25c; 1b., $75 \mathrm{c}$.

Coriunder for Flavoriug - Oz., $10 \mathrm{c} ; 2$ ozs., $15 \mathrm{c} ; 1 / 41 \mathrm{~b} ., 20 \mathrm{c} ; 1 \mathrm{~b} ., 75 \mathrm{c}$.

Dll- An annual, cultivated for its seed, which has an aromatic odor and a warm, pungent taste. It is good for flatulence and colic in infants and is sometimes added to pickled cucumbers to heighten the flavor. Sow early in spring and keep clear of weeds. Oz., 10c; 1/4 lb., $20 \mathrm{c}$; 1b., $60 \mathrm{c}$.

Maxioram, Sweet-A perennial plant, but not hardy enough to endure the winters of the North. The young tender tops are used green for flavoring or they may be dried for winter use. Sow in drils as early as possible, and thin out the plants to ten inches apart. Oz., 15c: $1 / 6$ 1b., $40 \mathrm{c}$; $1 \mathrm{~b} ., \$ 1.25$.

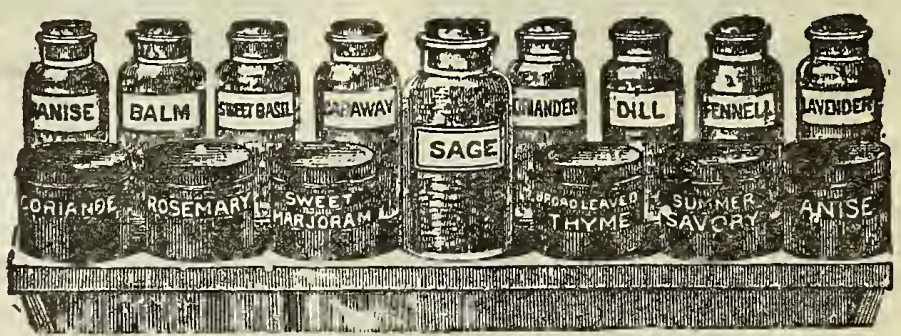

Rose, ary-A hardy perennial, with fragrari odo:, and a warm, bitter, aromatic taste. May easily oe raised from seed, but does not "each a size fit for ise until the second season.

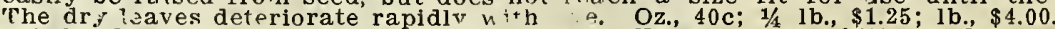

Rue-A hardy perenn:-1 with a per 1 iar smeli. The leaves are bitter and so acrid as to blister the skin. ${ }_{1}$ is a iimulant an anti-spasmodic, but must be used with great caution, as its use sometimes rosults in se, ous injury. It must not be suffered to run to seed, and does best on poor scil. Oz., $15 \mathrm{c}, 1 / 4$ 1b., $40 \mathrm{c} ; 1 \mathrm{~b} ., \$ 1.50$.

sage-A hardy pererital, possessing some medicinal properties, but cultivated principally for use as a condiment, it being used more extensively than any other herb for flavoring and dressing. Sow early in spring (four to five pounds per acre in drills) on very rich ground: dressing. Sow early in spring (four to five pounds per acre in drils) on very rich ground,

Ermmer Savory-A hardy annual, the dried stems, leaves and flowers of which are extensively used for flavoring, particularly in dressings and soups. Cultivate the same as Sweet Marjoram. Oz., 10c; $1 / 4$ lb., 30c; 1b., $\$ 1.00$.

Thime-This herb is perennial and is both a medicinal and culinary plant. The young leaves and tons are used for soups, dressing and sauce; a tea is made from the leaves, which is. a great remedy ill nervous headache. Sow as early as the ground will permit. Oz., 20c; $3 / \mathrm{lb} ., 60 \mathrm{c}$; 1b., $\$ 2.00$. 


\section{SWEET PEAS}

OUR SWEE' PEAS ARE UNSURPASSED FOR PURITY OF STRAIN. NO'THING BETIER IN THE U. S. THEY HAVE GIVEN WON DFEFUL SATISFAC'ION THE PAST

YEAR. IF YOU BUY OURS YOU BUY THE BEST.

The following varieties are selected with a view to please the most criticai, and we think the Cream of the List of Sweet Peas:

\section{LIGHT SHADES OE PINK}

Duchess of York-Standard and wings large and of fine form. White overlaid with a lacing of exceedingly delicate pale pink.

Eifza Eckford-Lalge flower of rosy pink over white, giving an exceedingly delicate and beautiful effect.

Katherine Tracy-The color is soft but brilliant pink, of the same shade in wings.

Loveir-A delicate shell pink tinged with yellow, producing a very warm, soft color of exceeding beauty.

Prima Donna--The stems bear three or four very large, perfect flowers, of brilliant, yet soft shade of pink.

Bamona-Large, finely formed flower; standard and wings white, but neàly covered with a very warm pink in small dots and shades.

Venus-Standard large, of fine form and substance; a brilliant but delicate and sort shade of warm rose-pink and buff.

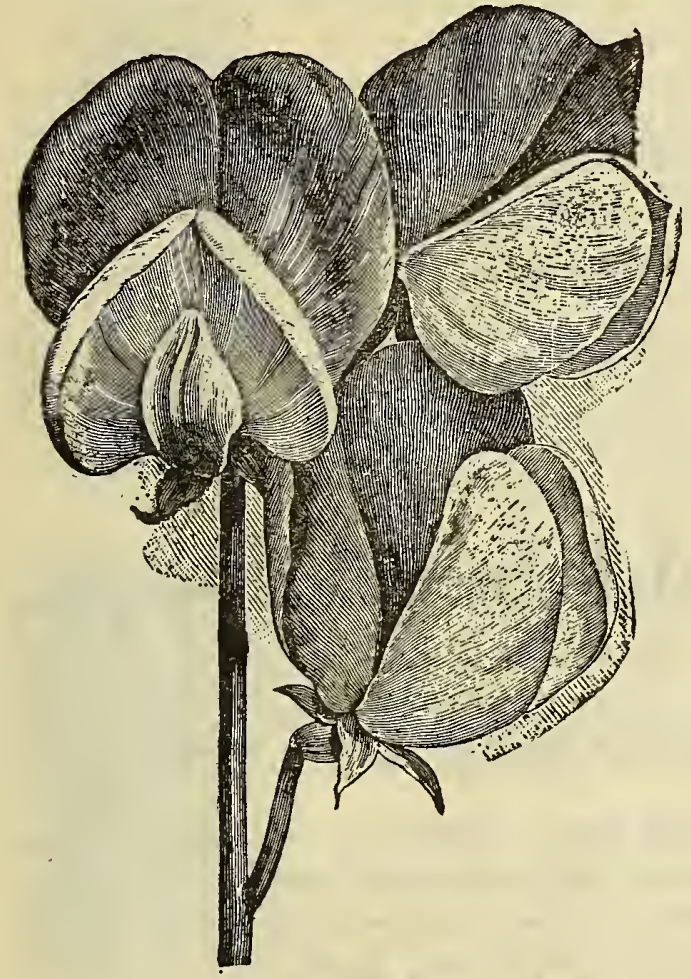

\section{DARKER SHADES OF PINK}

Apple Blossom-Standard rose-pink, lighter at the edges; wings lighter than standard. Her Majesty-The flowers are very large. a delicate rose-pink color.

a delicate rose-pink color. Lady Mary Currie-A large, well-
flower of brilliant orange-pink color.

Ovid-A good-sized, hooded flower of bright pink, overlaid with a darker shade.

Lady Penzance-A large and striking flower of a peculiar and beautiful shade of rosepink, with a slight tinge of orange.

Peach Blossom-A very large flower, having a warm yellowish-pink standard and wings of a lighter, softer shade.

Royai Rose-One of the largest and finest formed flowers yet produced. Standard a deep rose-pink.

Red or rose standurds with ligliter wingu. SHADES OF RED

Blanch Ferry-Standard medium-sized, but of fine form and bright pink color; wings large, rounded and nearly white.

Brilliant-Flower of good size and substance, color very brilliant $1 \cdot i c h$ red.

Firefly-Very bright, and intense crimson scarlet of good size and form.

Mrs. Dusiaie-A large finely formed flower of a peculiar shade of primrose overlaid with crimson rose.

Salopian-One of the most brilliant and most richly colored sorts yet introduced.

\section{CLARET AND MAROON}

Buke of Clarence-A fine flower with large standard and wings of uniform shade of dark claret.

Monarch-Standard large, fine form, violet maroon, wings very large and expanded.

Shahzada-This lias a very rich, dark maroon standard and deep violet wings; one of the finest dark sorts.

Sweet Peas

LAVENDER AND LIGHT BUUE

Countess of Radnor-Self-colored in a very distinct and beautiful shade of lavender. Dorothy Tennant-Flowers warm violet or mauve, very large and finely formed.

Lady Grisei Hamiiton-A large flower similar in color to the Countess of Radnor, but is nearly blue.

rottie Eckford-Standard a peculiar and delicate shade of magenta blue

Maid of Honor-Medium sized flower, nearly white, having a distinct edging of blue.

\section{BLUE AND PURPLE}

Black Kuight-The darkest variety.

Countess of Calogan-A variety having very long stems, each bearing three or four flowers. Captain of the Bines-Standard large, broad, bright purple blue; wings expanded, lighter and brighter blue than standard.

Navy Biue-A true blue, quite distinct.

\section{WHITE}

Blanche Burpee-A splendid pure white variety. While not so profuse a bloomer or as hardy a plant as the Emily Henderson, the individual flowers are so fine as to make it a most desirable sort.

Emily Henderson-A bold, well-formed, clear white flower. Wings broad and well expanded. An early and wonderfully free and persistent bloomer.

The Bride-The flowers are practically the same as the Blanche Burpee, but the stems are more slender. 


\section{SWEET PEAS-Continued}

\section{LIGHT VELLOW}

Primrose-Standard medium sized, rather long, yellowish white in iront, and pronounced primrose-yellow on the back.

Stella Morse-The large flowers of this variety are of the finest form and a peculiar warm solmon-pink.

Coquette-Large, finely formed Plower. Standard warm primrose with a shade of purple. Oriental-The large, finely formed flowers are a distinct bright orange of a very brilliant
and striking shade.

\section{STRIPED OR VARIEGATED}

America-White, nearly covered with splashes, stripes and dots of exceedingly bright cal mine; "he most brilliant of the red striped sorts.

Aurora-The staudard and wings are striped and flaked with delicate orange-salmon, pin ${ }^{2}$ over white.

Gray Friar-Very large, finely shaped flowers of delicate heliotrope color, peculiarly thgeu, marbled and dotted with darker shades.

Juanita-Large and splendidly formed; white, with stripes and dashes of delicate lavender. hrics. Joseph Chnmberlain-Very large and perfect shaped flowers; white, striped with bright rose carmine.

Princess of Wales-Standard broad, flat, striped purple on nearly white ground; wings very large and lighter than standard.

\section{MIXTURES OF SWEET PEAS}

CHOICE MIXED-One of the most satisfactory ways of growing sweet peas is in a mixed row. Many new combinations are obtained by cross-fertillzation, and if good varieties are planted, the result is sure to be satisfactory. Our Cloice Mixture has no superior; it is not composed of refuse stocks, but contains the finest known American kinds.

Eckford's Iybrids, Mixed-This is made up of the best of Eckford's large flowering sorts, carefully proportioned. As only Eckford's varieties are used in this mixture, some of our very best sorts are ilecessarily excluded; but it will give large, finely formed flowers in a great variety of beautiful colors.

\section{PRICES ON SWEE'T PEAS}

Named Varietles-As above Fancy Mixed-Made up by us from the above fifty-three varieties .......... Finest Mixed-As grown in the field.

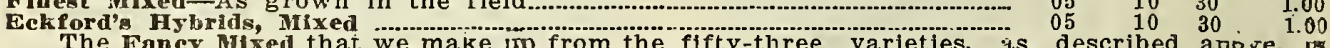
something superb and charming, $\bar{a} \bar{u} u$ will please the most festidious.

\section{Grass and Field Seed Dept.}

OUR SEEDS ARE UP TO STANDARD OF THE PURE SEED LAW OF THE STATE OW IOWA.

We do not deem it necessary to enter into an extended description of this branch of our business. In brief we only wish to say that at all seasons of the year we are prepared to furnish as choice a line of GRASS SEEDS and FIELD SWEDS as any market in the West. Wiih our superior milling facilities we are prepared to reclean and grade all classes of seeds and put them on the market in the very best shape.

THERE ARE NO SEGDS OFFERED THAT ARE FREER FROM FOUL SEED THAN OURS. OUR PIICES WILL BE FOUND AS LOW AS ANY IN THE NORTHWEST.

Anything in the above line you have to offer, send us a good sized sample by mail and we will make you highest market price.

WE CARRY ALNALFA, ALSYKE, BUCKWHEAT, KENTUCKY BLUE GRASS, ENGLISH BLUE GRASS, BROMUS INERMIS, CLOVER, DWARF ESSEX RAPE, LAWN GRASS, ORCHARD GRASS, RLD TOP, RYE GRASS, SUN FLOWER, SPELTZ OF FMMFR.

We Want to Buy anything in the above line you have to offer. Send us a good sized sample by mail and we will make you the highest market price.

\section{CLOVERS AND GRASSES}

The Clover and Grass Seed we handle are clcan and free of all foul and obnoxious weed seed. We invite every one interested to call and inspect our stocks before buying elsewhere. ALFA IFA CLOVIt - This rested to call and inspect our stocks before buying elsewhere. farmer has either heard of or knows its worth and merit. The plant grows, thrives and does well on any of our roiling prairies or well-drained bottom lands. Tle vigorous roots searching well on any of our roiling prairies or well-drained bottom lands. Tle vigorous roots searching stored in the earth for ages, leaving the land richer and better for succeeding crops than when lt was first sown. Three crops are often cut in one season, and from ten to twelve tons of excellent hay is the annual reward. One bushel of 60 lbs. will sow three acres. It should not be cropped or pastured the first year. Can be planted with a light nurse crop of barley, speltz or wheat. The stock we handle is the very best of hardy Northern-grown seed. We offer at present some choice Western-grown seed and Imported seed at prices ranging from $\$ 8$ to $\$ 9$ per bushel, subject to market changes.

MEDIUM RED CLOVER - This is by far the most important of all the varieties for practical purposes. Sow in spring or fall, and if no other grasses are used, at the rate of 15 pounds per acre; more is used on old soil than on new.

ALSIKE, or Svedish Ciover-The most hardy of all clovers. On rich, moist soll it yields an enormous quantity of hay or pasturage, but its greatest value is for sowing with other clovers ular, fragrant and much liked by bees, which obtain a large amount of honey from them. Sow in pipring or fall, at the rate of 10 pounds per acre, when ubod aione. 


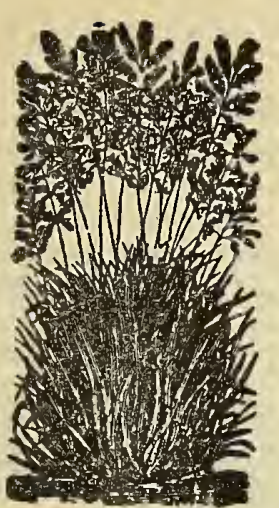

Kentucky Blue Graøs

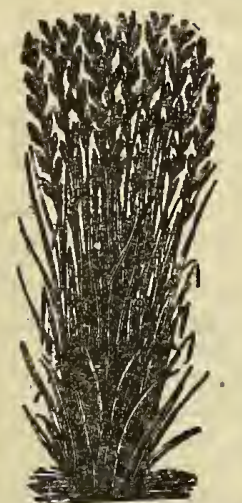

Itallan IRye Grass

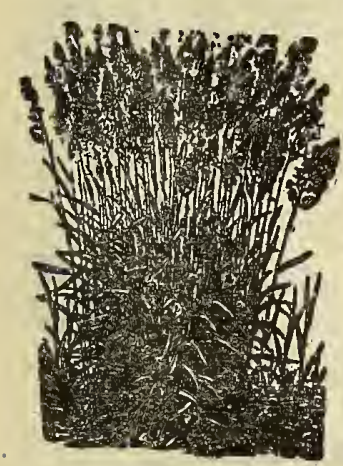

Red Top

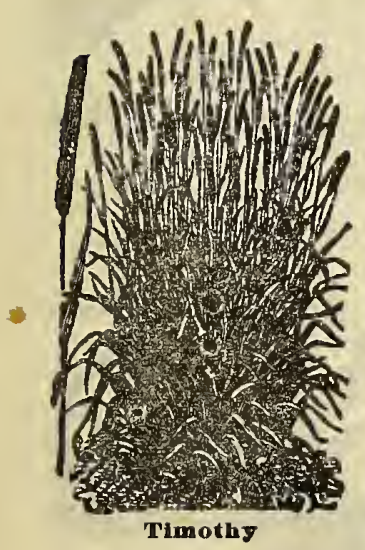

WHITE CLOVER-A small perennial variety. valuable for pasturage and for lawns. It accommodates itself to a variety of soils, and can be grown anywhere. Can be used to great adrantage in pasturing bixtures. Sow in spring, t the rate of eight to ten pounds per acre, or when used with other grasses, half that amount.

BROMUS INERMIS (Awnlesa Brome Grass)A hardy perennial, standing extremes of heat, cold and drouth better than any other of our cultivated grasses. Is especially adapted to the Northwest It grows with great rapidity and produces heavy hay crops and luxuriant pastures. All kinds of stock eat it greedily, and the analysis made shows that it is exceedingly rich in flesh-forming ingredients. Sow about 15 to 20 pounds to the acre.

KENTUCKY BLUW BRASS - The universal pasture grass of America and the finest lawn grass in the world is our own Kentucky Blue Grass. It starts like magic with the first smile of spring, and is a velvet of green until winte comes again. It can be sown on the wild prairie and will catch, but the best results are to be had by getting the seed well covered. The seed we offer comes directly from Kentucky in car lots and is fresh, clean and pure.

ENGLISH BLUE GRASS (Meadow Fegeue)-In Just a few yegrs this grass has come to th front like magic This is due to the fact that it is a success everywhere on all kinds of land and never freezes out. It comes early in the spring, is green all summer and lasts until late autunn. It's a nutritious pasture and a valuable hay crop, too. It's a perennial. 2 to 3 feet high, and heads out in June.

ITALIAN RYE GRASS-This grass, though but an ainual in this climate, produces such grea results that in a very short time after the seed is sown it makes as fine a pasture as other feet high. The leaves are very dark green with a ricli tint to the blade. It makes a pasture quick as oats, wheat, barley or rye would, and being a grass is of far greater value. It makes a splendic

ORCHARD GRASS-This Erass does well every where, and for hay can be cut much earlier than timothy. Succeeds the best of all grasses in timbered lands or orchards. Sow one to two bushels per acre.

TIMOTHY-This well-known grass is the best of all grasses for hay. Succeeds very well on all kinds of soil, but is well adapted to moderately moist land.

RED TOP-This grass is especially suited to low, wet spouty lands is in fact the only grass low, wet spouty lands; is in fact the only grass 'our northern winters, can be sown on wet land without cultivation, and will catch. Into the without cultivation, and will catch. Into the Wet soil it spreads its network of roots, tames the land and

GERMAN MILLET-Of all the different kinds of grass and forage plants raised for elther hay is the most widely known and extensively used. If drouths wither or rain and floods drown out and destroy the early planted fjelds of grain, Millet is the farmer's next resort. The Pure German Millet, of all the well-known kinds, is by far the most valuable. This wellknown sort reaches the acme of perfection in the more southern states and it is a fact that when the southern grown seed is planted in the north it produces a taller stalk and heavier growth of follage than can possibly be raised from our own northern grown seed. It is the judgment of those who have tried the seed from both sections side by side, the planter had better pay $\$ 2.00$ per bushel for pure, southern grown German Millet than to have the other as a gift.

SORGHUM (Sugar Cane for Fodder) -The greatest of all forage and fodder plants. It will yield two crops of fodder and a good fall pasture in one season. Roots deep into the subsoll and stands the drouths that often destroy other crops. As a rough provender it is unsurpassed. crops. As a rough provender

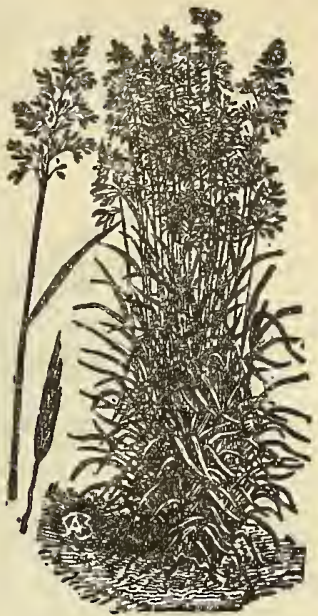

Bromus Inermis Graa:

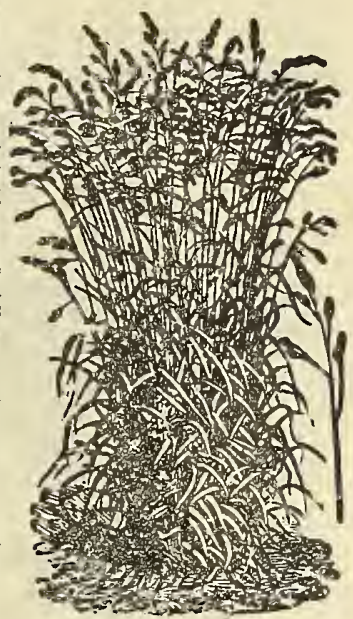

Englis Blue Grane

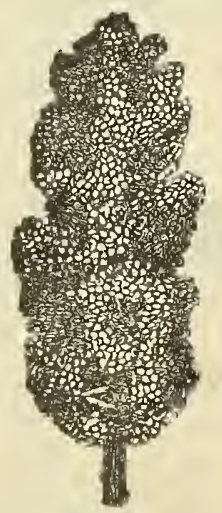

Kaffir 


\section{DRILLS AND SEEDERS}

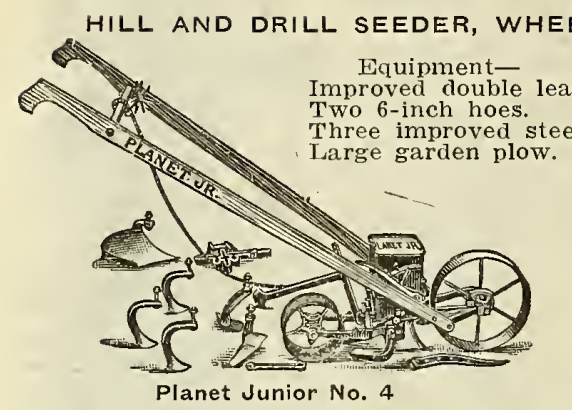

Planet Jr., No. 4
As a Seeder Only............\$10.75

Price, complete ............\$13.25

Packed welght, 58 lbs.

Combined seed Drill, Single Wheel Hoe, Cultivator and Plow. Price, $\$ 12.00$. Seeder Only, $\$ 10.00$.

The Extension Piece is used for hoeing both sides of the row at one passage while plants are small.

The Leaf Lifter is invaluable for late cultivation, making it quite easy to work crops close, without additional labor, when otherwise it would be impossible.

Rakes. We can supply three rakes with this machine, with three, five and seven teeth, respectively; valuable for fining and leveling the surface, and
rapid cultivation. Price, with these rakes, $\$ 16.00$.
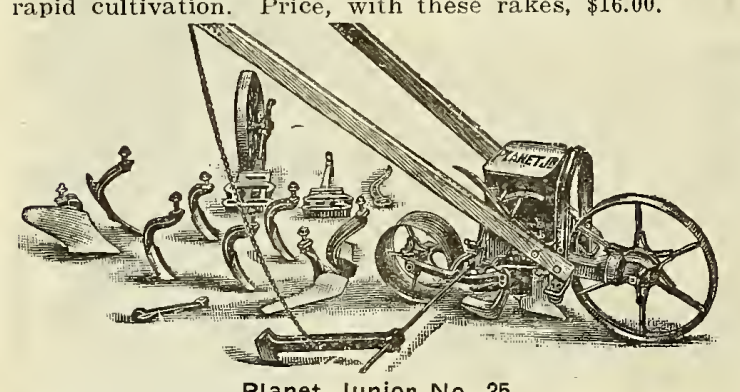

\section{Planet Jr., No. 25}

Comblned HIII and Drill Seeder, Double Wheel Hoe, Cultivator and Plow. Price $\$ 13.50$.

This new Combined Garden Planter No. 25 is the latest improved and most complete tool of its kind. It is wholly without a rival in its line. It is thoroughly substantial and accurate in planting all kinds of seeds, either in hills or drilling. By detaching planting apparatus it makes a double wheel hoe, a cultivator or plow. 111/4-inch wheels. Holds $21 / 2$ quarts. Weight packed, 59 pounds. It combines in a most practical way the Planet Jr. No. 4 Drill and No. 12 Double Wheel Hoe.

Equipment: One pair of six-inch hoes. Two pair of cultivator teeth. Two plows. Two leaf guards.

\section{Planet Junior}

12-Tooth Harrow, Cultivator and Pulverizer.

The farmer or gardener is most likely to cultivate best who has the tool best adapted to his purposes. With the Twelve-Tooth Harrow here shown you go as deep or shallow as you like, come up close to row without injuring plants, cut out all the weeds, stir the soil and mellow and fine it as with a garden rake. You widen and narrow as you please between i2 and widen and narrow as you please between 12 and
32 inches It's a special favorite with strawberry growers, market gardeners and truckers.

Price, Plain ..........................\$6.20 WIth Lever Wheei............................... 7.65 Complete, with Lever Wheel and Pulverizer... 9.25 Packed weight, 74 lbs.

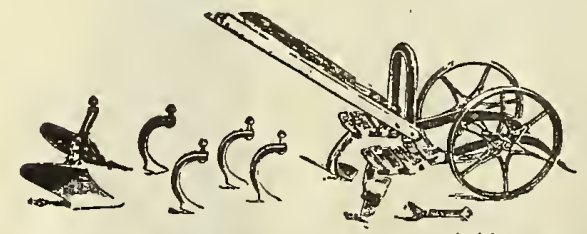

No. 12 Planet Jr., Double Wheel Hoe Packed weight, 32 lbs.

Price, with Attachments, as in cut, $\$ 8.75$.

One pair of 6 -inch hoes.

One pair of 6-inch hoes.

One pair of plows.

No. 12 Planet Jr. Double Wheel Hoe.

No. 18 Planet Jr. Single Wheel Hoe

Price, as in cut, $\$ 4.50$.

Packed weight, 20 lbs.
This is the same style as our other single wheel hoes, and the plow, cultivator teeth or rakes may any of them be added to the equipment, although it is better and cheaper to select and secure what you need with the original purchase.

No. 18 Planet Jr. SIngle Wheel Hoe.

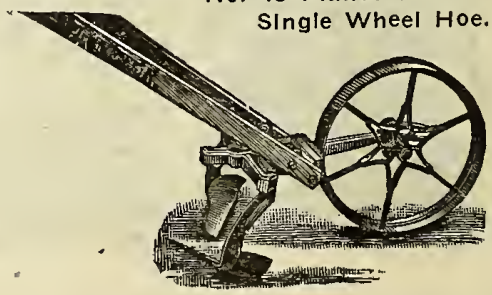




\section{"STANDARD" GARDEN TOOLS}

\section{WE HAVE SOLD THESE GARDEN TOOLS FOR FOUR YEARS WITH GREAT SATISFACTION}

\section{"Standard" No. 30 Cultivator}
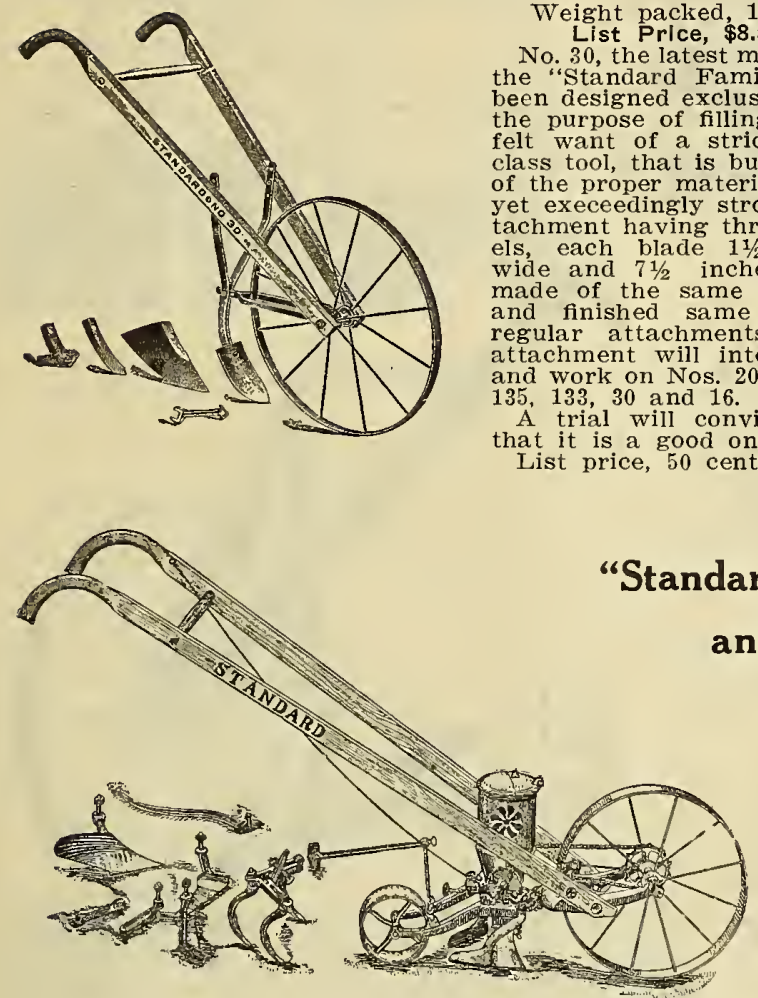

Weight packed, 16 lbs. List Price, $\$ 8.50$.

No. 30 , the latest member of the "Standard Family," has been designed exclusively for the purpose of filling a long felt want of a strictly first cin clas tool, that is built right, or the proper material, light, yet execedingly strong. At tachment having three shovels, each blade 11/2 inches wide and $7 \frac{1}{2}$ inches long, made of the same material and finished same as the regular attachments. This attachment will interchange and work on Nos. 20, 21, 136, $135,133,30$ and 16 .

A trial will convince you that it is a good one. List price, 50 cents.

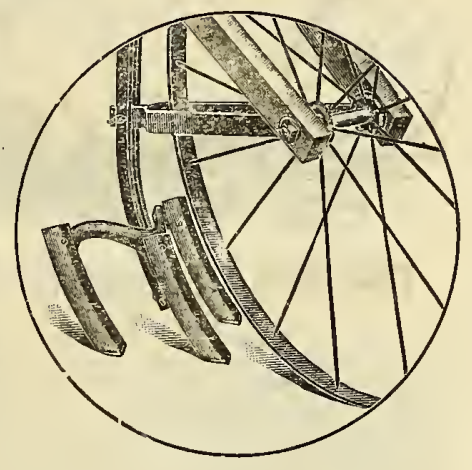

List Prlce, $\$ 12.00$.

No. 4 "Standard."

This is a first class combination in every respect; is a hill seeder, a drill seeder and a single wheel cultivator combined in one tool. Will plant seed in hills 4, 6, 8, 12 and 24 inches apart or drill in a continuous row.

\section{No. 2 "Standard"}

Spring Beam, Adjustable Arch, Double Wheel Hoe, Cultivator, Plow and Rake; No. 2, as shown with all attachments.

List Price, Complete, $\$ 7.00$.

WIth shovels and hoes, $\$ 5.25$.

This spring beam, double wheel tool is a great favorite with all who use it, owing to the fact that the attachments when in use are entirely under the operator's control. The handles being bolted to the spring beams allow the attachments to be moved to and from each other very easily.

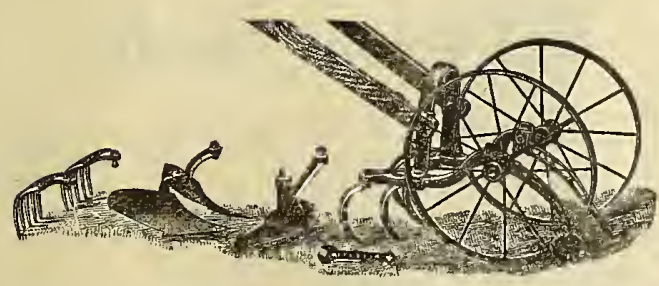

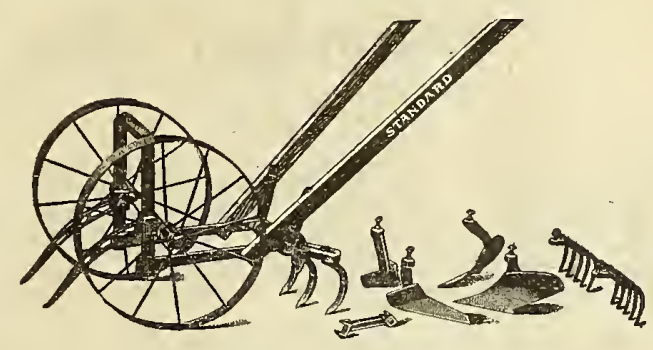

No. 2 "Standard"

\section{No. 4 "Standard"}

Double and SIngle Wheel Hoe, Cultivator

Rake and Plow

With all Attachments as shown, $\$ 8.00$.

This tool may be changed to a single wheel cultivator in a few seconds.

All castings are malleable, making it unbreakable.

The plows and hoes are of crucible steel.

All attachments are the best shapes, sizes and weights for the purpose. Just the thing for large or small gardens. 
No. 9 "Standard" Combined Double and Single Wheel Cultivator, Plow, Hoe, Rake, Hill and Drill Seeder

Prlce Complete, $\$ 13.00$.

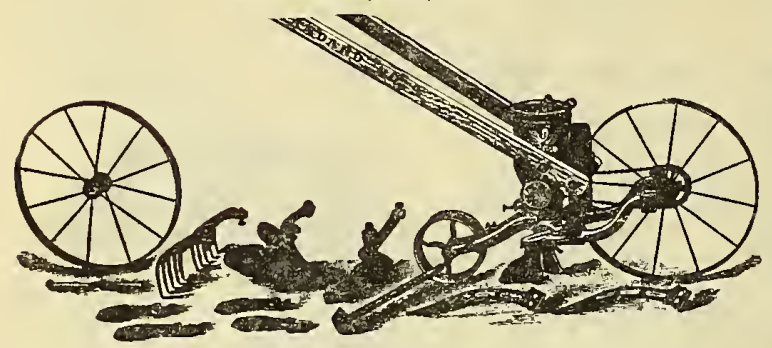

Will plant the seed in hills $4,6,8,12$ and 24 inches apart or drill in a continuous row. Both sides of the row may be plowed at once until the plants are too high, then the tool may be changed to a single wheel tool and used between the rows.

The attachments that go with this tool are 1 hill and drill seeder, 1 set of four cultivating teeth, 1 pair hoes, 1 pair plows, 1 pair rakes and 1 wrench. Each part is made of the best material for the purpose and works very accurately.

Wire wheels 16 inches high. Handles bent oak. Weight, packed ready to ship, 50 pounds. Every tool fully guaranteed.

\section{The New "Standard" No. 20}

\section{Price, $\$ 4.00$.}

This single-wheel plow has a 24-inch wheel which will make it the leader in its class.

The frame is the double pattern of very stiff

steel, holding the wheel true to its place.

The adjustment is the handiest and most perfect ever put on a tool of this kind and is adjusted up and down by loosening a thumb nut.

The handles are also adjusted by the same thumb nut without interfering with the plow adjustment.

"Standard" No. 22

List Price with Attachments Shown, $\$ 6.00$.
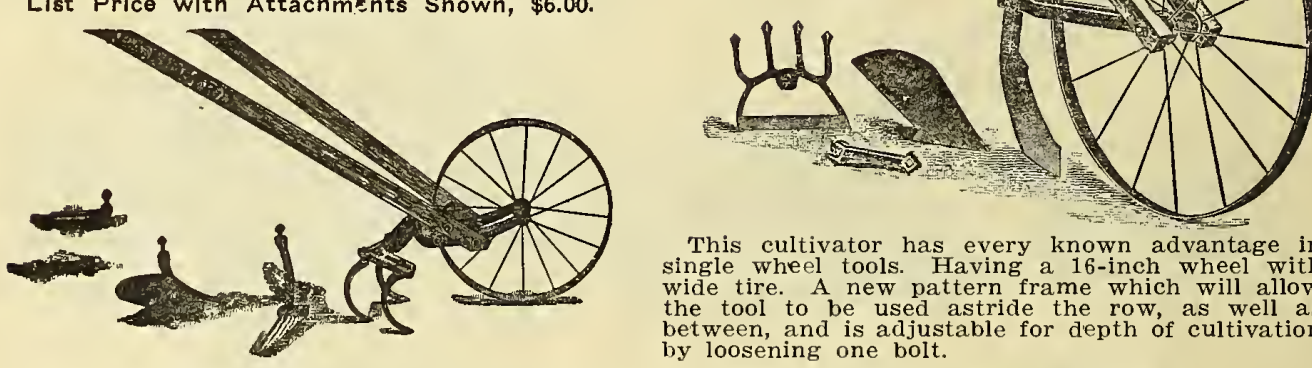

This cultivator has every known advantage in single wheel tools. Having a 16-inch wheel with wide tire. A new pattern frame which will allow the tool to be used astride the row, as well as between, and is adjustable for depth of cultivation by loosening one bolt.

\section{"Standard"}

Weight packed, $35 \mathrm{lbs}$.

$$
\text { LIst Price, } \$ 9.00 \text {. }
$$

Many farmers and gardeners have no use for a hill seeder. To meet this demand we offer our No. 25 Drill only. While the working parts are the same the frame is steel and constructed in a very substantial and workmanlike manner. The feed is taken care of by a rotary agitator brush of the proper size and shape to give a constant flow of seed, without injury to the seed.

Chain adjustment is made by loosening the bolts at the lower end of the handle braces and moving the hopper slightly backward and forward.

Front wheel is 16 inches in diameter with tire $1 \frac{1}{2}$ inches wide.

The marker is very simple and convenient and provided with a notch in the frame to hang up out of the way when not in use.

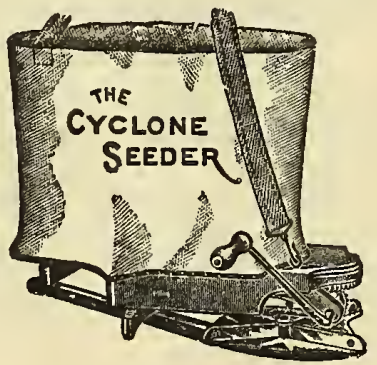

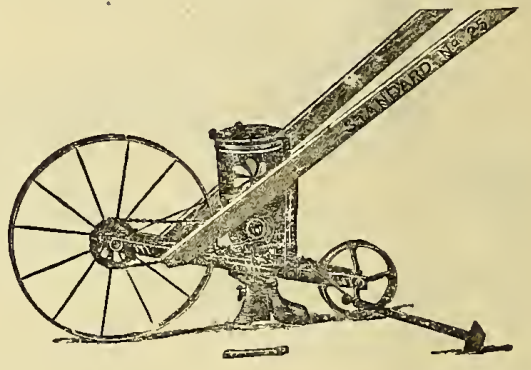

\section{Cyclone Seeder}

It is especially designed for distributing evenly all kinds of grain as well as every variety of grass seed.

The construction is simple, strong and practical. 


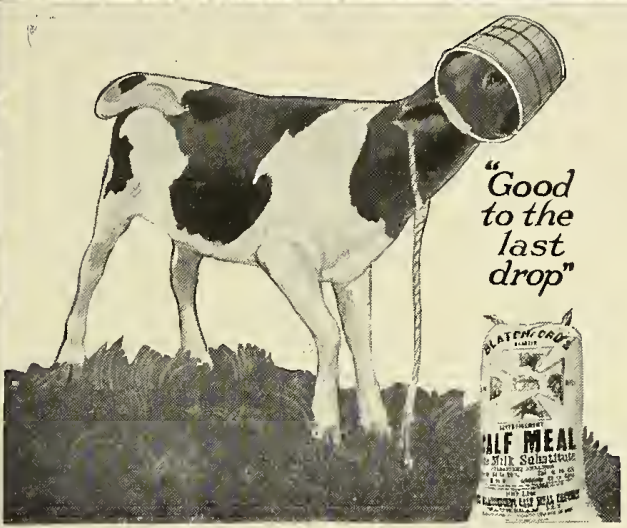

More than double

your profits with

Blatchford's

Calf Meal

The complete milk equal

THIS is in reality a substitute for milk--and should I not be considered as an ordinary "feed" or "meal." It contains all the elements of milk and when properly prepared becomes a "baby food" for the calves. It is just the thing for weaning the calves as soon as they can be taken away from the cow. Then all the milk may be sold and you get the benefit of the high creamery prices.

It is absolutely the only milk substitute that contains all the elements necessary for rapid and healthy growth, and the only calf meal that is thoroughly cooked and prepared for digestion.

Will push calves forward better and quicker than any other feed

Prices: 25-lb. bag, $\$ 1.00,50-l b . b a g, \$ 2.00,100-l b . b a g, \$ 3.50$

100 pounds makes 100 zallons of Complete Milk Equal

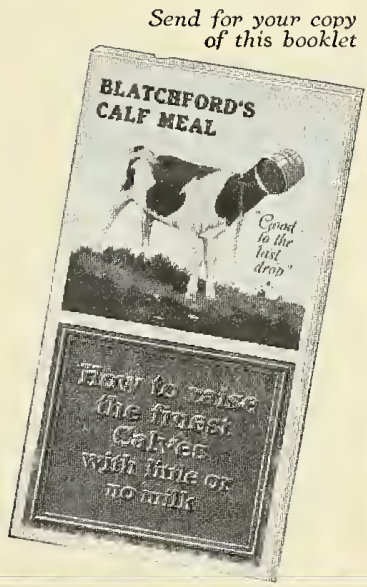

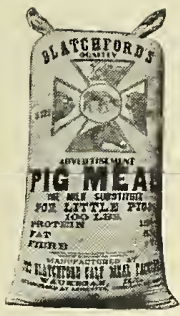

Wean your little pizs early, quickly and safely on our complete milk equal for pizs

\section{Blatchford's Pis Meal}

contains just the right percentage of vegetable protein, fat, moisture, ash, etc, for this work. It keeps the pißgs growing sturdily, rapidly and profitably instead of taking on excess far.

It grows bone and solid flesh, prevents losses of growth and vitality during the critical weaning period and always makes the runts catch up.

Prices: $25-l b . \mathrm{ba}, \$ 1.00,50-l b . b a \hat{B}, \$ 2.00$, $100-l b . b a \mathrm{~B}, \$ 3.50$
All the ingredients of Blatchford's Pig Meal are contained in

\section{Blatchford's Lamb Meal}

and in addition an extra quantity of sweet honey locust bean, which is particularly attractive to young lambs, quickly prevents scours and setbacks and is a complete equal for the ewe's milk.

When about ten days or two weeks old, lambs will be found nibbling at the feedtroußh. Encouraße them with Blatchford's Lamb Meal and your profits will increase

Prices: $25-1 b . b a z, \$ 1.00,50-l b . b a k, \$ 2.00$, $100-l b, b a \mathrm{~g}, \$ 3.50$

\section{Blatchford's Milk Mash}

is a perfect milk substitute for baby chicks from the shell up to three months old, usually raisinz a hundred per cent hatch-and have no bowel trouble. Indispensable for fatteninè broilers, roasters and capons, and putting show birds in the pink of condition for poultry shows.

Five pounds raises one chick from the shell up to three months old.

Prices: 25-lb, baz, $\$ 0.90$ $100-1 b, b a \beta, \$ 3.25$

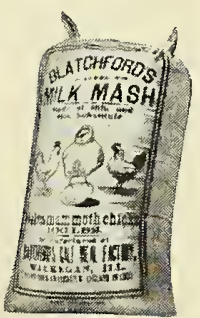

\section{Blatchford's "Fill the Basket" EgBz Mash}

carries a hish percentage of surplus nourishment and will produce hundred esss for less money than any other feed on the market.

Instead of considering the cost per 100 pounds of feed, consider the cost per log chas ard ycu vill use lad.

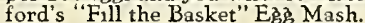
It starts the pullets laying between five and six months of age naturally, without forcins, keeping them in perfect health all the time.

Prices: 25-lb. bas, $\$ 0.80$, $100-l b . b a g, \$ 3.00$

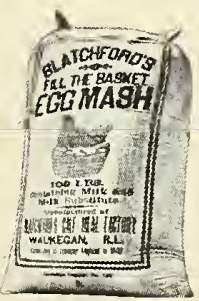




\section{POULTRY FOODS}

\section{OUR FOODS ARE HONEST}

ACME, No Grit, Scratch Food EUREKA, No Grit, Chick Food

STARTER, No Grit, Baby Chick Food

PURITY, No Grit, Chick Food

STANDARD, Scratch Food, small per cent Grit
ECLIPSE, Chick Food, small \% Grit. FORCING POULTRY MASH.

Our Foods have no Dust, no Damaged Grain. No Shells. No Screenings. No by-products.

ALL FOOD-NO WASTE

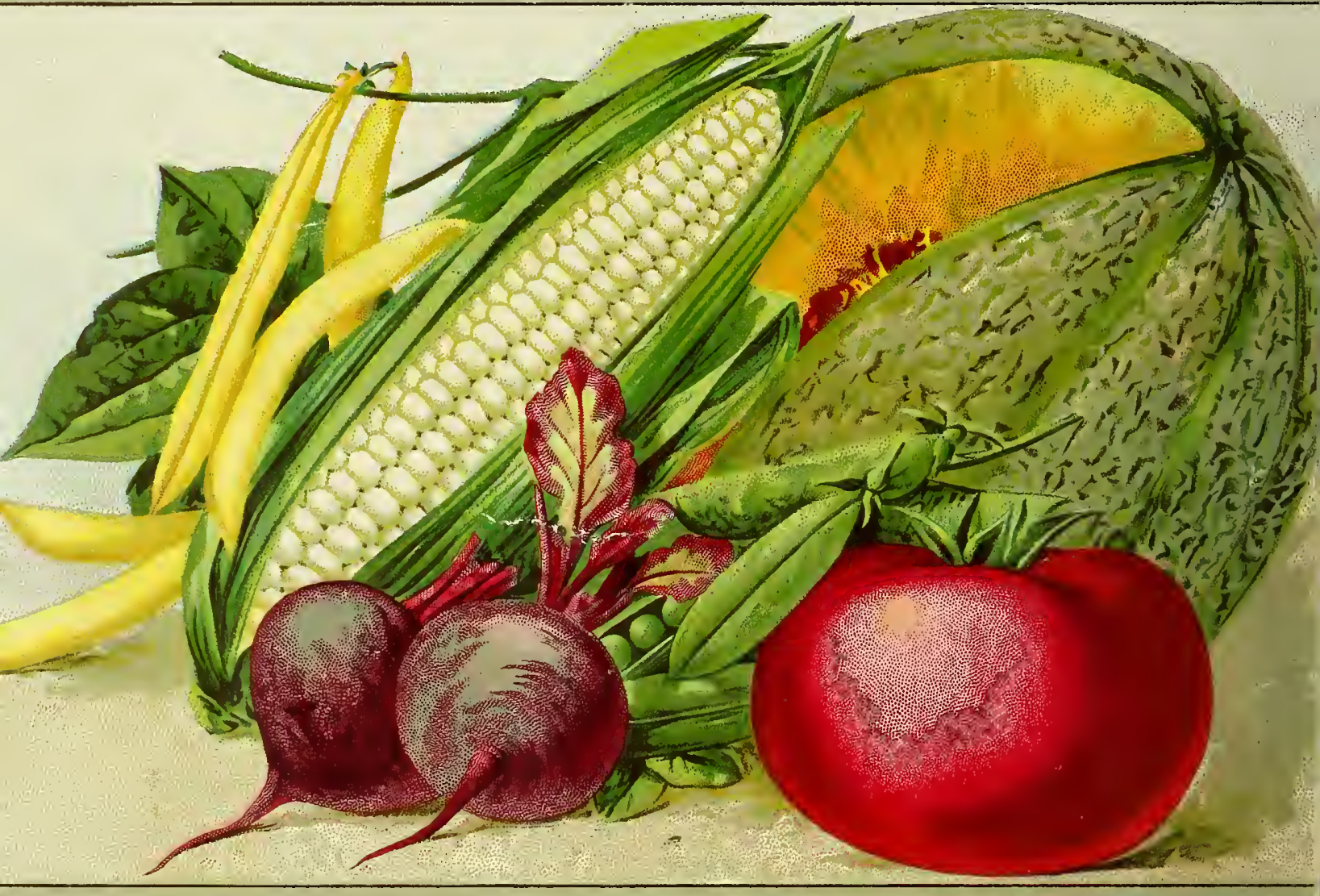

STECHER COROEHESTER, N.Y.

\section{OUR LINE OF POULTRY SUPPLIES IS COMPLETE}

Oyster Shells, Clam Shells, Mica Grit, Pearl Grit, Crys-co Grit, Charcoal, Beef Scraps, Broom Corn Millet, Kaffir Corn, Cracked Peas, Alfalfa Meal, Alfalfa and Syrup, Cracked Rice, Meat Meal 60\%,
Meat Meal 45\%, Blood Meal, Meat \& Bone, Cotton Seed Meal, Hemp and Canary Bird Rape, Steel Cut Oats, Sunflower, Poultry Bone. Mash. 